\title{
Site Observational Work Plan FOR THE UMTRA PROJECT SITE AT SHIPROCK, NeW MEXICO
}

\section{RECEIVED \\ AUG 151995 \\ OSTI}

\section{July 1995}

\section{DISCLAIMER}

This report was prepared as an account of work sponsored by an agency of the United States Government. Neither the United States Government nor any agency thereof, nor any of their employees, makes any warranty, express or implied, or assumes any legal liability or responsibility for the accuracy, completeness, or usefulness of any information, apparatus, product, or process disclosed, or represents that its use would not infringe privately owned rights. Reference herein to any specific commercial product, process, or service by trade name, trademark, manufacturer, or otherwise does not necessarily constitute or imply its endorsement, recommendation, or favoring by the United States Government or any agency thereof. The views and opinions of authors expressed herein do not necessarily state or reflect those of the United States Government or any agency thereof. 


\section{DISCLAIMER}

Portions of this document may be illegible in electronic image products. Images are produced from the best available original document. 


\section{INTENDED FOR PUBLIC RELEASE}

This report has been reproduced from the best available copy. Available in paper copy and microfiche.

Number of pages in this report: 92

DOE and DOE contractors can obtain copies of this report from:

Office of Scientific and Technical Information

P.0. Box 62

Oak Ridge, TN 37831

(615) 576-8401

This report is publicly available from:

National Technical Information Service

Department of Commerce

5285 Port Royal Road

Springfield, VA 22161

(703) 487-4650 
DOE/AL/62350-158

REV. 0

\section{SITE OBSERVATIONAL WORK PLAN FOR THE UMTRA PROJECT SITE \\ AT SHIPROCK, NEW MEXICO}

July 1995

Prepared for

U.S. Department of Energy UMTRA Project Office

Albuquerque, New Mexico

Prepared by

Jacobs Engineering Group Inc.

Albuquerque, New Mexico 
TABLE OF CONTENTS

Section

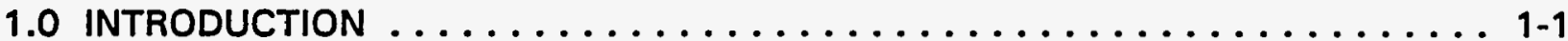

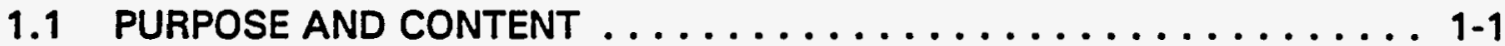

1.2 GROUND WATER COMPLIANCE STRATEGIES $\ldots \ldots \ldots \ldots \ldots \ldots \ldots \ldots$

1.3 RELATIONSHIP TO PROGRAMMATIC UMTRA GROUND WATER DOCUMENTS ............................. 1-2

1.4 RELATIONSHIP TO SITE-SPECIFIC DOCUMENTS . . . . . . . . . . . 1-2

2.0 REGULATORY FRAMEWORK . . . . . . . . . . . . . . . . 2-1

2.1 URANIUM MILL TAILINGS RADIATION CONTROL ACT . . . . . . . . 2-1

2.1.1 Environmental Protection Agency ground water standards . . . 2-1

2.1.2 Cooperative agreements .................... 2-4

2.2 NATIONAL ENVIRONMENTAL POLICY ACT $\ldots \ldots \ldots \ldots \ldots \ldots \ldots$

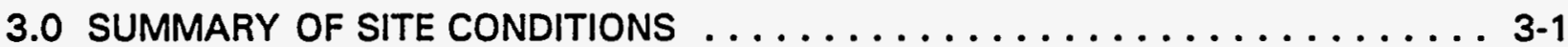

3.1 SITE HISTORY ... . . . . . . . . . . . . . . . . . 3-1

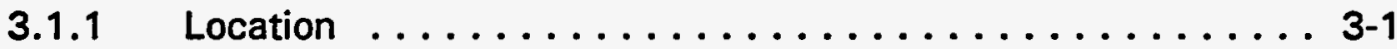

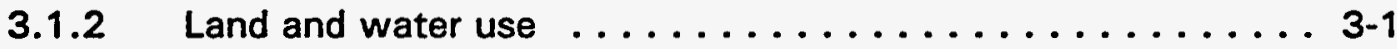

3.1 .3 History of operations . ..................... $3-4$

3.1.4 Surface remedial action and ground water protection

strategy ........................... 3-7

3.2 SOURCES OF EXISTING DATA $\ldots \ldots \ldots \ldots \ldots \ldots \ldots \ldots \ldots \ldots \ldots \ldots$

3.3 CONCEPTUAL SITE MODEL . . . . . . . . . . . . . . . 3-8

3.3.1 Hydrogeologic setting ....................... 3-8

3.3.2 Ground and surface water quality ................ . . 3-20

3.3.3 Contaminant fate and transport ................ 3-34

3.3.4 Risk evaluation . . . . . . . . . . . . . . . . . . . 3-40

3.4 EVALUATION OF INTERIM ACTION OPPORTUNITIES $\ldots \ldots \ldots \ldots \ldots . . . .3-42$

4.0 GROUND WATER COMPLIANCE STRATEGY SELECTION . . . . . . . . . . 4-1

4.1 GROUND WATER COMPLIANCE STRATEGY . . . . . . . . . . . . 4-1

4.2 SITE-SPECIFIC GROUND WATER COMPLIANCE STRATEGIES . . . . . . 4-1

4.2.1 Terrace compliance strategy . . . . . . . . . . . . . . . 4-4

4.2 .2 Floodplain compliance strategy $\ldots \ldots \ldots \ldots \ldots \ldots \ldots$. . . . . . . 4

4.3 DEVIATIONS, CONTINGENCIES, AND DECISION RULES $\ldots . . . . . .44$

4.3 .1 Terrace aquifer . . . . . . . . . . . . . . . . . 4-7

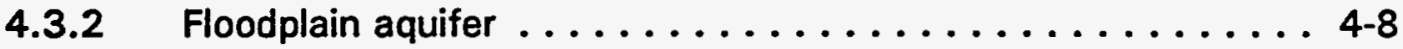

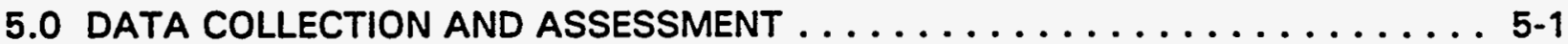

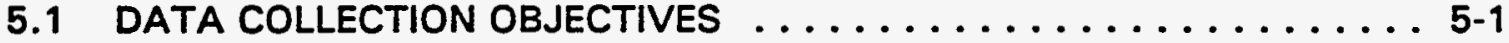

5.2 STATEMENT OF DATA NEEDS $\ldots \ldots \ldots \ldots \ldots \ldots \ldots \ldots \ldots \ldots \ldots \ldots \ldots$

5.3 DATA COLLECTION ACTIVITIES AND OUALITY OBJECTIVES $\ldots \ldots \ldots$ 5-2

5.3.1 Surface geophysical surveys ............... 5-3

5.3.2 Borehole fluid conductivity surveys .............. 5-6

$5.3 .3 \quad$ Core analysis . . . . . . . . . . . . . . . . . 5-6 
TABLE OF CONTENTS (Concluded)

Section

Page

5.3.4 Monitor well installation $\ldots \ldots \ldots \ldots \ldots \ldots \ldots$. . . . . . . . . . . . . . . . . .

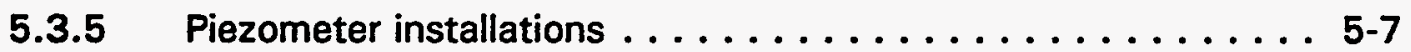

5.3.6 Aquifer testing . . . . . . . . . . . . . . . . . . 5-8

5.3.7 Water quality sampling and analysis . . . . . . . . . . . 5-9

5.3.8 Geochemical analysis of lithologic samples ... . . . . . . 5-10

5.3.9 Biological sampling of ground water . . . . . . . . . 5-10

5.3.10 Surface water and sediment sampling ............ 5-11

5.4 RESULTS AND EVALUATION OF DATA COLLECTION ACTIVITIES . . 5-11

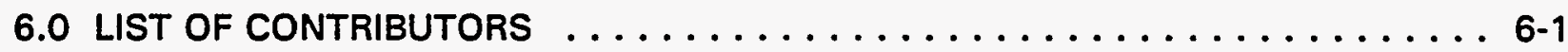

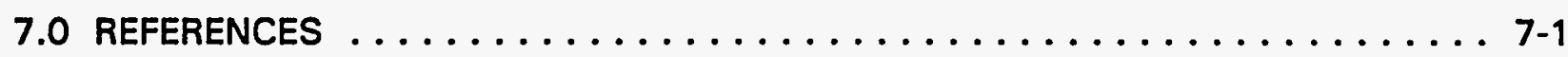




\section{LIST OF FIGURES}

Figure

Page

Figure 3.1 Shiprock site location map, Shiprock, New Mexico . . . . . . . . . 3-2

Figure 3.2 Physiographic setting, Shiprock, New Mexico, site . . . . . . . . . . 3-3

Figure 3.3 Aerial view of Shiprock site in operating period, Shiprock, New

Mexico, site . . . . . . . . . . . . . . . . . . . . . . . 3-5

Figure 3.4 Conceptualized cross section A-A', Shiprock, New Mexico, site . . . . . 3-9

Figure 3.5 Bedrock surface contours on terrace, Shiprock, New Mexico, site . . . . 3-11

Figure 3.6 Bedrock surface contours on floodplain, Shiprock, New Mexico, site . . 3-15

Figure 3.7 Fence diagram of floodplain stratigraphy, Shiprock, New Mexico, site . 3-16

Figure 3.8 Ground water table contours and gradient on floodplain, Shiprock,

New Mexico, site . . . . . . . . . . . . . . . . . . . . 3-17

Figure 3.9 Ground water monitor well locations, Shiprock, New Mexico, site ... 3-19

Figure 3.10 Locations of floodplain surface water and sediment sampling stations

adjacent to Shiprock tailings site, Shiprock, New Mexico, site . . . . . . 3-21

Figure 3.11 Background wells used for qualitative (SJ3, G10) and quantitative $(732,733,634,635)$ analysis of ground water in the floodplain aquifer, Shiprock, New Mexico, site . . . . . . . . . . . . . . . . 3-25

Figure 3.12 Sulfate concentrations in floodplain alluvium, Shiprock, New Mexico, site ............................... 3-31

Figure 3.13 Nitrate concentrations in floodplain alluvium, Shiprock, New Mexico, site ............................... 3-32

Figure 3.14 Uranium concentrations in floodplain alluvium, Shiprock, New Mexico, site ................................. 3-33

Figure 4.1 Shiprock terrace compliance selection framework, Shiprock, New Mexico, site . . . . . . . . . . . . . . . . . . . . . . . . . 4-2

Figure 4.2 Shiprock floodplain compliance selection framework, Shiprock, New Mexico, site . . . . . . . . . . . . . . . . . . . . . . . . 4-3

Figure 4.3 Application of constituents to compliance selection framework for the floodplain, Shiprock, New Mexico, site . . . . . . . . . . . . . . . . . 4-5

Figure 5.1 Location for surface geophysical surveys, Shiprock, New Mexico, site . . 5-6 


\section{LIST OF TABLES}

Table

Page

Table 2.1 Maximum concentrations of inorganic constituents for ground water protection for UMTRA Project sites . . . . . . . . . . . . . . 2-3

Table 3.1 Monitor well information, Shiprock, New Mexico, site . . . . . . . . . 3-22

Table 3.2 Statistical summary of contaminants of potential concern in the San Juan River floodplain aquifer, 1987-1993 filtered samples, Shiprock, New Mexico, site . . . . . . . . . . . . . . . . . . . . . 3-26

Table 3.3 Summary of contaminants of potential concern in ground water in the terrace aquifer, Shiprock, New Mexico, site, 1988-1993 . . . . . . . . 3-29

Table 3.4 Statistical summary of the San Juan River water quality at the Shiprock, New Mexico, site, February 25, 1993 . . . . . . . . . . 3-35 
LIST OF ACRONYMS

Acronym Definition

ACL alternate concentration limit

AEC

Atomic Energy Commission

ASTM

American Society for Testing Materials

DCO

data collection objective

DO

dissolved oxygen

DOE

U.S. Department of Energy

DQO

EM

data quality objective

EPA

electromagnetic

GWPP

U.S. Environmental Protection Agency

$M C L$

MSL

NEPA

NRC

NTUA

Groundwater Project Plan

maximum concentration limit

mean sea level

National Environmental Policy Act

PEIS

U.S. Nuclear Regulatory Commission

Navajo Tribal Utility Authority

programmatic environmental impact statement

RAP

RRM

remedial action plan

SOP

residual radioactive material

standard operating procedure

SOWP

site observational work plan

TAC

Technical Assistance Contractor

TAGR

TDS

Technical Approach to Groundwater Restoration

total dissolved solids

TEM

transient electromagnetic

UMTRA

Uranium Mill Tailings Remedial Action

UMTRCA

Uranium Mill Tailings Radiation Control Act 


\section{EXECUTIVE SUMMARY}

The site observational work plan (SOWP) for the Shiprock, New Mexico, Uranium Mill Tailings Remedial Action (UMTRA) Project Site is one of the first documents for developing an approach for achieving ground water compliance at the site. This SOWP applies Shiprock site information to a regulatory compliance framework, which identifies strategies for meeting ground water compliance at the site. The compliance framework was developed in the UMTRA ground water programmatic environmental impact statement (DOE, 1995).

The U.S. Department of Energy's goal is to implement a site strategy that complies with U.S. Environmental Protection Agency ground water standards and is protective of human health and the environment at the least cost. The compliance strategies that emerge in the SOWP final version subsequently will be presented in an environmental assessment to assess potential environmental impacts of their implementation and to provide stakeholders the opportunity to review and comment. If the compliance strategies are determined acceptable, the strategies will be detailed in a remedial action plan subject to review by the tribe and concurrence by the U.S. Nuclear Regulatory Commission.

The Shiprock site consists of two, interconnected hydrogeologic systems: the terrace system and the floodplain system. Based on information available for the preparation of this SOWP, two different compliance strategies appear to be appropriate for these systems. The most likely compliance strategy for the terrace aquifer is no remediation with the application of supplemental standards based on classification of the terrace aquifer as having limited-use ground water. The most likely compliance strategy for the floodplain aquifer is active remediation using one or more remediation technologies currently under evaluation.

The site conceptual model, described in this SOWP, indicates that milling-related contamination has impacted the ground water in the terrace and floodplain aquifers at the Shiprock site. Ground water occurs in both aquifers in alluvium and in fractures in the underlying Cretaceous age Mancos Shale. A mound of milling-related ground water is thought to exist in the terrace aquifer beneath the area where settling ponds were used during the mill operations. Most of the water occurring in the floodplain aquifer is from recharge from the San Juan River.

Recovery data from monitor wells on the terrace suggest that the terrace aquifer has a very low yield. Therefore, the small amount of ground water naturally occurring in the terrace aquifer qualifies the ground water as limited-use based on a sustained well yield of less than 150 gallons (570 liters) per day.

Contamination in the floodplain aquifer comes from the mound of milling-related water in the terrace by way of seeps along the escarpment and possibly by flow through fractures in the Mancos Shale. During the operation of the mill, process waters may have been diverted to settling ponds on the floodplain and may have spilled onto the floodplain by overflowing from the settling ponds on the terrace. Because contaminated ground water in the floodplain aquifer has higher densities than unimpacted ground water, it may be 
immobilized in low areas of erosional structures on the top of the Mancos Shale. The presence of immobilized water may impact the remediation technology selection for the floodplain aquifer. Nineteen potential contaminants of concern are in ground water in the terrace and floodplain aquifers. Active remediation of the floodplain aquifer is needed to mitigate any risks to human health and the environment from these constituents in ground water at the site.

An assessment of site-specific data indicates that additional data must be collected before a remediation technology can be suggested for the site. This SOWP suggests a variety of data collection activities to fulfill these data needs. The data to be collected during these activities will help define the horizontal and vertical extents of contamination in ground water, characterize aquifer properties, and define biological and geochemical processes in the aquifer. These data will then be used to determine the effectiveness of the currently identified compliance strategies and the feasibility of remediation technologies for the floodplain aquifer. 


\subsection{INTRODUCTION}

The Shiprock, New Mexico, site observational work plan (SOWP) will be used to develop an approach for achieving compliance with the U.S. Environmental Protection Agency (EPA) ground water standards (40 CFR Part 192; 60 FR 2854) as part of the U.S. Department of Energy (DOE) Uranium Mill Tailings Remedial Action (UMTRA) Ground Water Project.

\subsection{PURPOSE AND CONTENT}

The purpose of this SOWP is to document the observational approach, to recommend additional data collection efforts, and to assist in selecting the appropriate ground water compliance strategies. The SOWP summarizes site conditions, presents a site conceptual model based on existing characterization data, identifies the most likely site-specific compliance strategies, and defines data collection activities to address uncertainties. The site conceptual model describes the sources of the contaminants of potential concern and defines the current conditions and potential environmental and human health risks. This SOWP identifies data gaps in the site conceptual model and presents defensible data collection objectives (DCO) and appropriate data quality objectives (DOO) for conducting additional field work. The SOWP will be revised to incorporate the results of further data collection activities and stakeholder comments.

Section 2.0 describes the regulatory framework guiding the selection of ground water compliance strategies for UMTRA Project sites. Section 3.0 defines the current conditions at Shiprock and presents the site conceptual model, which includes potential environmental and human health risks, that supports the ground water compliance strategies. Section 4.0 provides the decision-making framework used to arrive at the most likely ground water compliance strategies. Section 5.0 presents additional data collection needs and activities to refine the site conceptual model and the evaluation of remediation technologies.

Three versions of the SOWP will be prepared: Revision 0 (initial submittal), Revision 1, and Revision 2 (final revision). Following this initial SOWP, Revision 1 will include all previously existing ground water data from the site, describe the additional data collected and the DOOs used, address changes in the site conceptual model and the recommended compliance strategies as a result of the new information, and summarize the results relative to the DCOs. Revision 1 will also propose a pilot field program for observing the effectiveness of the recommended remediation technology. The final revision (Revision 2) of the Shiprock SOWP will be prepared after review by affected stakeholders and resolution of comments. 


\subsection{GROUND WATER COMPLIANCE STRATEGIES}

This SOWP identifies two likely ground water compliance strategies for the Shiprock site corresponding to two distinct, ground water systems: the terrace system and the floodplain system. The most likely ground water compliance strategy for the terrace system is no remediation. This strategy is based on the application of supplemental standards because the ground water can be classified as limited-use ground water (aquifer yield is less than 150 gallons [gal] (570 liters [L]) per day, 40 CFR \$192.11(e); 60 FR 2854) and there is no human health or environmental risk of applying supplemental standards. The most likely ground water compliance strategy for the floodplain system may be active ground water remediation. There are 19 contaminants of potential concern within the floodplain aquifer. Active ground water remediation is recommended to attain the EPA's maximum concentration limits (MCL) or background concentration levels as required for the UMTRA Project.

\subsection{RELATIONSHIP TO PROGRAMMATIC UMTRA GROUND WATER DOCUMENTS}

Programmatic documents that provide guidance for the SOWP include the UMTRA Groundwater Project Plan (GWPP) (DOE, 1992), the Draft Programmatic Environmental Impact Statement for the Uranium Mill Tailings Remedial Action Ground Water Project (PEIS) (DOE, 1995), and the Technical Approach to Groundwater Restoration (TAGR) (DOE, 1993a). The GWPP states the mission, need, and objectives for the UMTRA Ground Water Project and provides an overall technical and management approach for conducting the Ground Water Project. The PEIS provides an objective programmatic decision-making framework for conducting the UMTRA Ground Water Project, assesses the potential programmatic impacts of conducting the Project, provides a framework for determining the site-specific ground water compliance strategies, and provides data and information that can be used to prepare site-specific environmental impact analyses more efficiently. The TAGR provides technical guidance for conducting the Ground Water Project.

\subsection{RELATIONSHIP TO SITE-SPECIFIC DOCUMENTS}

The surface remedial action plan (RAP) provides site characterization information (DOE, 1985). This information is updated for the SOWP to formulate the site conceptual model. If a ground water compliance strategy requiring remedial action activities is selected for this site, a ground water RAP or surface RAP modification will be prepared.

In 1994, a baseline risk assessment was prepared for the site (DOE, 1994a). The document identifies the potential public health and environmental risks at the site. Potential risks identified in the risk assessment are considered in this SOWP to ensure that the compliance strategies considered are protective of human health and the environment. 
After identification of a proposed compliance strategy(ies) in the final SOWP, a site-specific National Environmental Policy Act (NEPA) document (e.g., environmental assessment) will be prepared to determine the potential impacts, if any, of implementing the most likely compliance strategy(ies). 


\subsection{REGULATORY FRAMEWORK}

This SOWP begins the process to select two ground water compliance strategies for the Shiprock site to achieve compliance with the EPA ground water standards applicable to Title I UMTRA Project processing sites (40 CFR Part 192; 60 FR 2854). This section identifies the relationship of the Uranium Mill Tailings Radiation Control Act (UMTRCA), the EPA standards, the cooperative agreements, and the NEPA to the UMTRA Ground Water Project.

\subsection{URANIUM MILL TAILINGS RADIATION CONTROL ACT}

The U.S. Congress passed the UMTRCA (42 USC $\$ 7901$ et seq.) in 1978 in response to public concerns about the potential health hazards from exposure to uranium mill tailings over long periods of time. The UMTRCA authorized the DOE to stabilize, dispose of, and control uranium mill tailings and other contaminated materials at uranium mill processing sites.

The UMTRCA has three titles that apply to uranium processing sites. Title 1 of the Act designates 24 inactive processing sites that will undergo remediation; directs the EPA to promulgate standards; mandates remedial action in accordance with standards prescribed by the EPA; directs remedial action to be selected and performed with the concurrence of the U.S. Nuclear Regulatory Commission (NRC) and in consultation with states and Indian tribes; directs the NRC to license the disposal sites for long-term care; and directs the DOE to enter into cooperative agreements with the affected states and Indian tribes. Title II applies to active uranium mills, and Title III applies to certain uranium mills in New Mexico. The UMTRA Project has responsibility for administering only Title $I$ of the UMTRCA.

In 1988, Congress amended the UMTRCA Amendments Act (Amendments Act; 42 USC \$7923), authorizing the DOE to extend without limitation the time needed to complete ground water remediation activities at the processing sites.

\subsubsection{Environmental Protection Agency ground water standards}

The UMTRCA requires that the EPA promulgate standards for protecting human health and the environment from hazardous constituents associated with the processing of uranium and the resulting residual radioactive materials (RRM). On 5 January 1983, the EPA published standards (40 CFR Part 192) for the disposal and cleanup of RRM. The standards were revised and a final rule was published on 11 January 1995 (60 FR 2854).

The standards address two ground water contamination scenarios. The first addresses future ground water contamination that may occur from tailings piles after disposal; the second addresses the cleanup of contamination that occurred at the processing sites before disposal of the tailings piles (60 FR 2854). Future protection of the ground water at the disposal sites is being addressed in the 
UMTRA Surface Project with the design of disposal cells and the long-term surveillance plans. The UMTRA Ground Water Project addresses the residual contamination that occurred at the processing sites before the surface remedial action was completed and is regulated by Subparts $B$ and $C$ of the EPA standards.

Subpart B, "Standards for Cleanup of Land and Buildings Contaminated with Residual Radioactive Materials from Inactive Uranium Processing Sites" (60 FR $2867)$ requires that remedial action at processing sites be conducted to ensure that the amounts of RRM in ground water meet any one of three criteria specified:

- Background level - concentration of a constituent in the uppermost aquifer that was not affected by processing activities.

- MCL - the EPA's maximum limits for concentrations of certain hazardous constituents in ground water for the UMTRA Project. The MCLs for inorganic constituents that apply to UMTRA Project sites are given in Table 2.1.

- Alternate concentration limit $(A C L)$ - alternate limits for hazardous constituents that do not pose a substantial present or potential hazard to human health or the environment, as long as the limit is not exceeded. An ACL may be applied after considering options to achieve background levels or MCLS.

Under certain specific conditions, the DOE may apply supplemental standards to contaminated ground water in lieu of background levels, MCLs, or ACLs 160 FR 2854). Supplemental standards may be applied if any one of the following conditions is met:

- Remedial actions necessary to implement Subpart A or B would pose a significant risk to workers or members of the public.

- Remedial actions to meet the standards would directly produce environmental harm that is clearly excessive compared to the health benefits of remediation to persons living on or near the sites, now or in the future.

- The estimated cost of remedial action is unreasonably high relative to the long-term benefits, and the RRMs do not pose a clear present or future hazard.

- There is no known remedial action.

- The remediation of ground water quality at any processing site is technically impracticable from an engineering standpoint. 
Table 2.1 Maximum concentrations of inorganic constituents for ground water protection at UMTRA Project sites ${ }^{a}$

\begin{tabular}{|c|c|}
\hline Constituent & $\mathrm{MCL}^{\mathrm{b}}$ \\
\hline Arsenic & 0.05 \\
\hline Barium & 1.0 \\
\hline Cadmium & 0.01 \\
\hline Chromium & 0.05 \\
\hline Lead & 0.05 \\
\hline Mercury & 0.002 \\
\hline Molybdenum & 0.1 \\
\hline Nitrate (as N) & $10.0^{c}$ \\
\hline Selenium & 0.01 \\
\hline Silver & 0.05 \\
\hline Combined radium-226 and radium-228 & $5 \mathrm{pCi} / \mathrm{L}$ \\
\hline Combined uranium-234 and uranium-238 & $30 \mathrm{pCi} / \mathrm{L}^{\mathrm{d}}$ \\
\hline $\begin{array}{l}\text { Gross alpha-particle activity } \\
\text { (excluding radon and uranium) }\end{array}$ & $15 \mathrm{pCi} / \mathrm{L}$ \\
\hline \multicolumn{2}{|c|}{$\begin{array}{l}\text { a } 40 \text { CFR } \$ 264.94,60 \mathrm{FR} 2866 \text {. } \\
\text { b Milligrams per liter (mg/L) unless otherwise noted. } \\
\text { CEquivalent to } 44 \mathrm{mg} / \mathrm{L} \text { nitrate as nitrate (NO }{ }^{3-} \text { ). } \\
\text { dEquivalent to } 0.044 \mathrm{mg} / \mathrm{L} \text { assumes secular equilibrium } \\
\text { between } 234 \text { and } 238 .\end{array}$} \\
\hline
\end{tabular}


- The ground water is classified as limited-use ground water. Subpart B of the EPA standards defines limited-use ground water as ground water that is not a current or potential source of drinking water because total dissolved solids (TDS) exceed 10,000 milligrams per liter (mg/L); there is widespread ambient contamination that cannot be cleaned up using treatment methods reasonably employed in public water supply systems; or the quantity of water available is less than $150 \mathrm{gal}(570 \mathrm{~L}$ ) per day (60 FR 2867). When limited-use ground water applies, supplemental standards shall ensure that current and reasonably projected uses of the ground water are preserved (60 FR 2868).

- Radiation from radionuclides other than radium-226 and its decay products (e.g., thorium-230) is present in sufficient quantity and concentration to constitute a significant radiation hazard from RRMs.

Subpart B also provides for selecting natural flushing as a means to meet the EPA standards. Natural flushing means allowing natural ground water processes to reduce the contamination in ground water to the standards (background levels, MCLs, or ACLs). Natural flushing must allow the standards to be met within 100 years. In addition, ground water must not be currently, or projected to become, a source of drinking water during the period of natural flushing. Institutional controls (measures that restrict access to contamination, protect human health, and satisfy beneficial uses of ground water) must be established and maintained during the period of natural flushing.

Subpart C "Implementation," provides guidance for implementing methods and procedures to provide reasonable assurance that the provisions of Subpart B are satisfied. Subpart $C$ requires that the conditions of Subpart $B$ be met on a sitespecific basis, using information gathered from site characterization and monitoring. Subpart $C$ also requires that the plan meet the conditions of Subpart B as stated in the compliance strategy plan or RAP that contains the compliance strategy, a demonstration of effectiveness, and a monitoring program, if required.

\subsubsection{Cooperative agreements}

The UMTRCA requires that remedial action be accomplished with the full participation of the affected states and Indian tribes on whose lands the uranium mill tailings are located. The UMTRCA also directed the DOE to enter into cooperative agreements with the states and Indian tribes.

\subsection{NATIONAL ENVIRONMENTAL POLICY ACT}

Implementation of the UMTRCA represents a major federal action subject to the requirements of the NEPA of 1969 (42 USC $\$ 4321$ et seq.). The Council on Environmental Quality's regulations that implement the NEPA are codified in 40 CFR Part 1500-1508. The regulations require that each federal agency develop its own implementing procedures (40 CFR \$1507.3). The DOE NEPA 
regulations are contained in the "National Environmental Policy Act Implementing Procedures" (10 CFR Part 1021). DOE guidance is provided in Recommendations for the Preparation of Environmental Assessments and Environmental Impact Statements (DOE, 1993b).

Pursuant to the NEPA, the DOE drafted a PEIS in 1994 for the UMTRA Ground Water Project to analyze potential impacts of implementing four programmatic alternatives for conducting ground water compliance at the UMTRA Project processing sites. The preferred alternative will be selected by the DOE and published in a record of decision. All subsequent actions on the UMTRA Ground Water Project must comply with this record of decision.

The environmental impacts from implementing the most likely compliance strategies presented in the final Shiprock SOWP will be addressed in a sitespecific NEPA document that will meet the requirements of the NEPA and tier off applicable issues discussed in the PEIS. 


\subsection{SUMMARY OF SITE CONDITIONS}

\subsection{SITE HISTORY}

\subsubsection{Location}

The Shiprock site is located on the Navajo Indian reservation east of U.S. Highway 666 and south of U.S. Highway 64, and 1 mile (mi) (1.6 kilometers [km]) south of the town of Shiprock, San Juan County, in northwest New Mexico. Farmington, New Mexico, is approximately $30 \mathrm{mi}(50 \mathrm{~km})$ east of the Shiprock site (Figure 3.1).

The former Shiprock mill site and disposal cell are located on top of a river terrace south and west of the San Juan River (Figure 3.2). Southwest of the site, the terrace slopes gently upward for approximately 2500 feet $(\mathrm{ft})(760$ meters [m]) where it meets the upland area. The terrace is relatively level, with elevation ranging from a high of approximately $4980 \mathrm{ft}(1520 \mathrm{~m})$ above mean sea level (MSL) along the southwestern edge of the property to a low of about $4950 \mathrm{ft}(1510 \mathrm{~m})$ at the escarpment. A 50 -ft $(15-\mathrm{m})$-high, northwest-southeast trending escarpment separates the terrace from a floodplain situated along the west bank of the San Juan River. The San Juan River flows in a northwesterly direction through the floodplain.

The floodplain of the San Juan River is located at the base of the escarpment east and north of the completed uranium mill tailings disposal cell. It begins approximately $1000 \mathrm{ft}(300 \mathrm{~m})$ upstream of the former mill site, widens to about $1500 \mathrm{ft}(460 \mathrm{~m})$, then pinches out against the escarpment at the point where the San Juan River passes under the U.S. Highway 666 bridge approximately $2200 \mathrm{ft}(670 \mathrm{~m})$ downstream of the northwestern corner of the former mill site. Because the only practical access to the cliffs is from the floodplain, any environmental considerations associated with the escarpment are included with the floodplain for the purposes of this document.

Two arroyos are located east and west of the tailings site. Bob Lee Wash is an arroyo bordering the western side of the site. Many Devils Wash parallels Bob Lee Wash approximately $2500 \mathrm{ft}(760 \mathrm{~m})$ southeast of the site.

\subsubsection{Land and water use}

Shiprock had a reported population of 7687 in 1990 (DOC, 1990). A mix of residential and commercial development exists near the site. A U.S. Public Health Service building, Navajo Engineering and Construction Authority facilities, Abandoned Mine Land Program office buildings, and fairgrounds are immediately west of the former mill site. West of U.S. Highway 666 is a residential area with a day care center and community development offices. A residential area is located northwest of Bob Lee Wash. In addition, approximately 10 households are located southwest of the disposal site. Some livestock and 

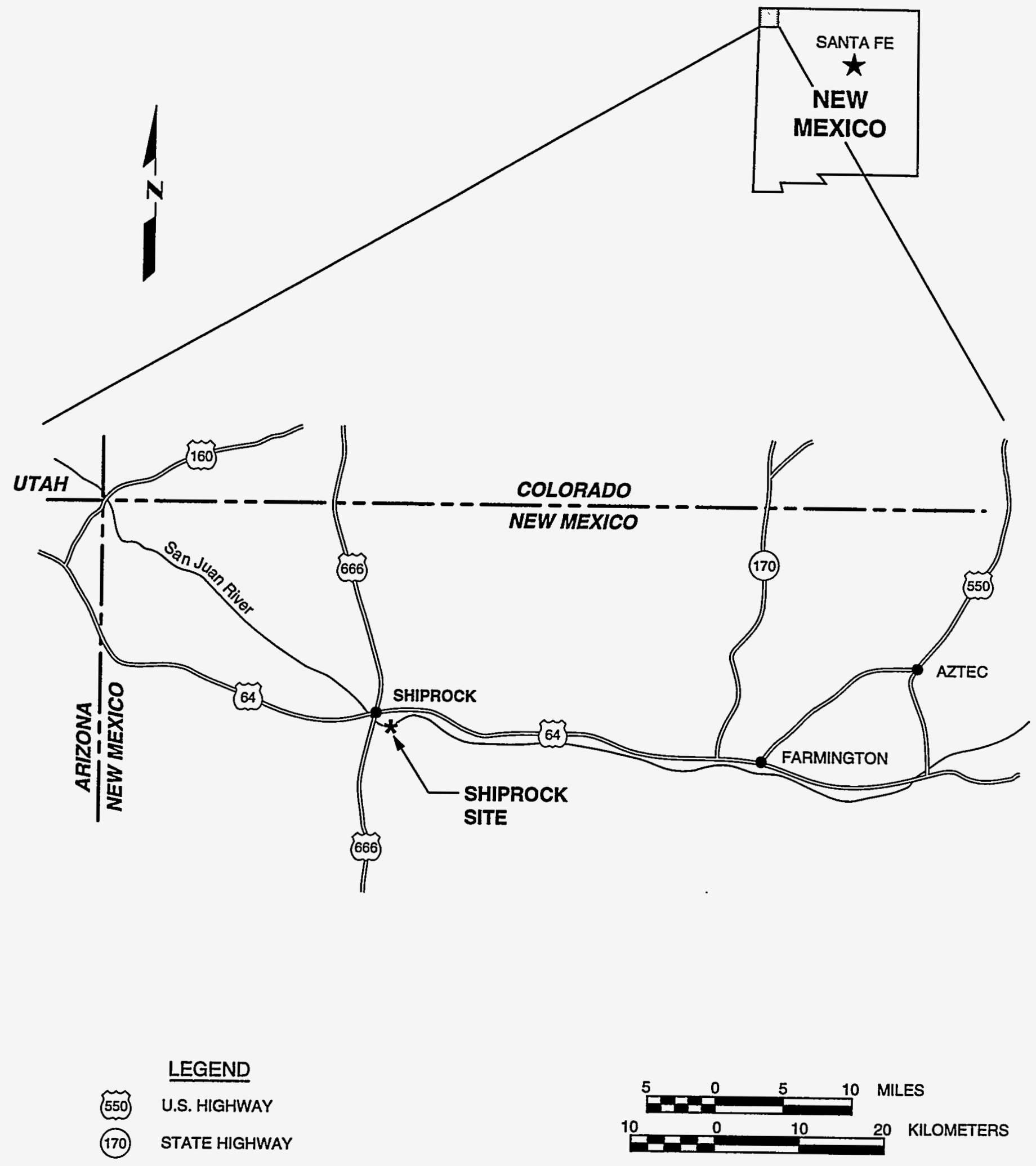

FIGURE 3.1

SHIPROCK SITE LOCATION MAP SHIPROCK, NEW MEXICO 


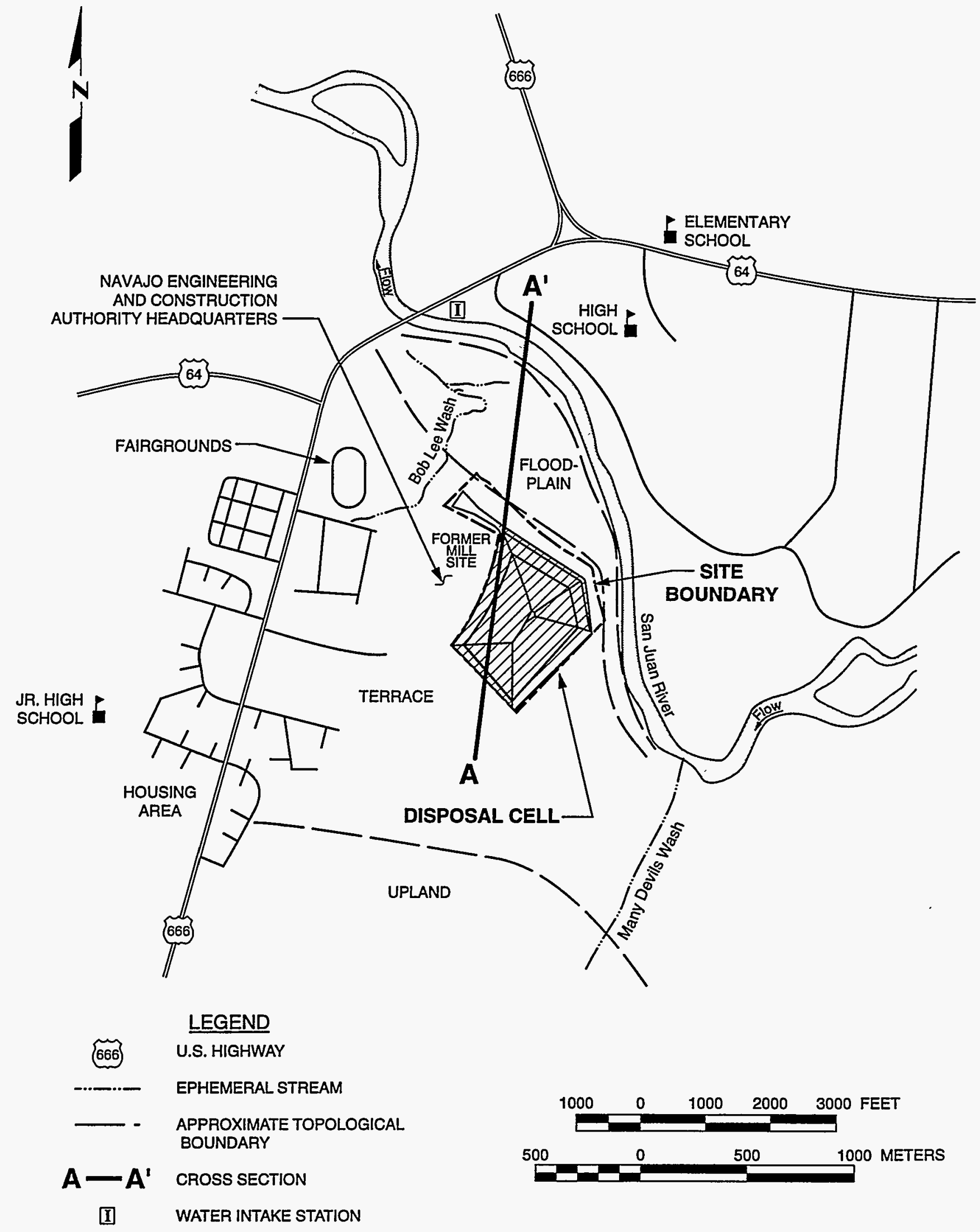

FIGURE 3.2

PHYSIOGRAPHIC SETTING SHIPROCK, NEW MEXICO, SITE 
domestic animals are raised by these individual households near the site. Although a grazing permit has been issued for the floodplain below the site by the Bureau of Indian Affairs, no grazing has occurred since the site was fenced off in July 1986.

No water supply wells completed in the alluvium of the floodplain aquifer on the southwest side of the river near the site were identified in a field search in 1993. Treated San Juan River water is provided by the Navajo Tribal Utility Authority (NTUA) to these residences as well as the facilities and buildings described above. One NTUA water supply intake is located on the northeast side of the river $300 \mathrm{ft}(90 \mathrm{~m})$ upstream of the U.S. Highway 666 bridge over the San Juan River. The intake structure is visible from the floodplain across the river. Pumps for this intake are installed approximately $15 \mathrm{ft}(5 \mathrm{~m})$ below the river surface. An infiltration gallery that measures approximately $300 \mathrm{ft}$ $(90 \mathrm{~m})$ in length and consists of a nominal 6-inch (15-centimeter [cm]) diameter transit pipe may be related to this intake structure. The pipe runs under the river and may extend somewhat into the floodplain (Public Health Service, 1962). It is uncertain if the transit pipe is still in service as part of the intake structure. Approximately 30 percent of the NTUA's water that is treated is drawn from this intake point.

\subsubsection{History of operations}

The former Navajo Mill at the Shiprock site was constructed and operated from 1954 to 1963 by Kerr-McGee Oil Industries, Inc., and from 1963 to 1968 by Vanadium Corporation of America and its successor, Foote Mineral Company. Before and during the milling operations, the site was leased from the Navajo Nation. The lease expired in 1973.

The mill reportedly processed approximately 1.5 million short tons (1.4 million metric tons) of ore along with smaller quantities of bulk precipitates from heap leach operations from the Monument Valley area and from purchased vanadium liquor (DOE, 1985). Ore processing consisted of crushing, leaching with sulfuric acid, washing, and extracting uranium and vanadium with organic solvents (di[2-ethylhexyl] phosphoric acid and tributyl phosphate in kerosene). Both nitrate and ammonium complexes were used as ion exchange strippers to concentrate the uranium, and ammonia was used to adjust the $\mathrm{pH}$ of the slurry during the milling process. Tailings from the washing circuit and yellow cake filtrates were pumped to tailings disposal areas. Raffinate (the fluid remaining after the uranium has been removed from the process water) was allowed to evaporate in separate unlined ponds to the west and southeast of the tailings piles (Figure 3.3).

An average of about 400 to 500 short tons (360 to 450 metric tons) of ore were processed daily using the acid leaching process between 1954 and 1963 when Kerr-McGee operated the mill. From 1963 to 1968, the heap leaching operations were also conducted at the mill (Merritt, 1971). Water for the mill and plant operation was taken from the San Juan River just upstream of the 


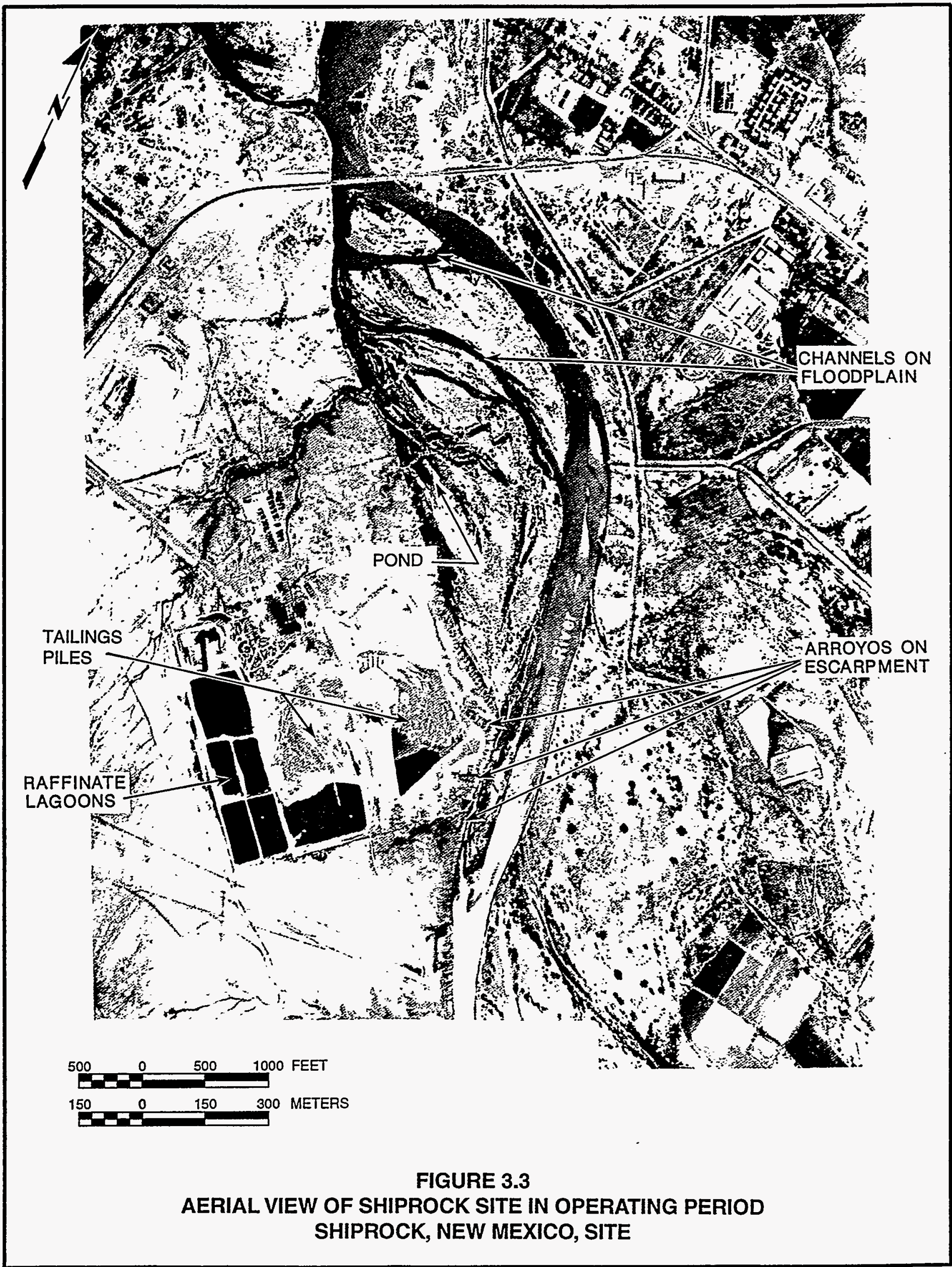


mill. Kerr-McGee had two water withdrawal permits, NM 2807 and NM 2875, for 500 and 700 acre-feet $\left(620,000\right.$ and 860,000 cubic meters $\left.\left[\mathrm{m}^{3}\right]\right)$ per year, respectively.

An order of magnitude estimate has been made of water use and disposal. For the acid leach process, water use was approximately 720 to $1200 \mathrm{gal}$ (2700 to $4500 \mathrm{~L}$ ) of water per ton of ore processed. Assuming about 400 short tons (360 metric tons) of ore were processed per day, water use would have been approximately 38,000 gal ( 1.5 million $L$ ) using an average water use of $960 \mathrm{gal}$ $(3600 \mathrm{~L})$ per ton of processed ore. If it is further assumed that ore was processed 24 hours per day, this results in a water use rate of approximately 270 gallons per minute (gpm) (1000 liters per minute [L/min]) (Merritt, 1971). All process water and slimes were discharged to unlined ponds. These ponds were used for evaporation and allowed the water to percolate into the underlying soil and rock beneath the ponds. In addition, the mill cooling water, approximately $130 \mathrm{gpm}(490 \mathrm{~L} / \mathrm{min})$, was piped to a separate pond that discharged to Bob Lee Wash on the west side of the mill (Public Health Survey, 1962). The cooling water was at times contaminated due to overflow of contaminated process waters. The total estimated water flow was approximately $400 \mathrm{gpm}(1500 \mathrm{~L} / \mathrm{min})$ or 54 percent of the Kerr-McGee surface water flow rights. A pond of unknown purpose was situated on the floodplain during the operation of the mill (Figure 3.3).

The mill had approximately 20 acres (ac) ( 8 hectares [ha]) of ponds for storage, evaporation, and percolation of the process water. Water that did not evaporate was allowed to percolate through the pond bottoms to the ground water below. The yearly average net evaporation rate (pan evaporation less rainfall) for the Shiprock site is approximately 65 inches $(170 \mathrm{~cm})$ (DOE, 1984).

A flow rate of $270 \mathrm{gpm}(1000 \mathrm{~L} / \mathrm{min})$ is equivalent to 435 acre-feet $\left(537,000 \mathrm{~m}^{3}\right)$ per year. With a net evaporation rate of 65 inches $(170 \mathrm{~cm}) \mathrm{per}$ year, and 20 ac $(8 \mathrm{ha})$ of ponds, an average of 108 acre-feet $\left(133,000 \mathrm{~m}^{3}\right)$ of water could have evaporated per year, or approximately $72 \mathrm{gpm}(270 \mathrm{~L} / \mathrm{min})$. A 1960 Atomic Energy Commission (AEC) document (AEC, 1960), estimated that approximately $160 \mathrm{gpm}(610 \mathrm{~L} / \mathrm{min})$, or 60 percent of the estimated $270 \mathrm{gpm}$ (1000 L/min) process water discharged to the ponds, seeped out of the bottom of the ponds. Together, the estimate of evaporation losses of $72 \mathrm{gpm}$ $(270 \mathrm{~L} / \mathrm{min})$ and the estimated $160 \mathrm{gpm}(610 \mathrm{~L} / \mathrm{min})$ seepage losses account for $230 \mathrm{gpm}(880 \mathrm{~L} / \mathrm{min})$, close to the $270 \mathrm{gpm}(1000 \mathrm{~L} / \mathrm{min})$ of process water estimated to have been used at the plant.

In 1960, seepage from various seeps on the escarpment in the area of the mill site ranged from about 0.5 to $20 \mathrm{gpm}(2$ to $80 \mathrm{~L} / \mathrm{min})$ and totaled approximately $50 \mathrm{gpm}(200 \mathrm{~L} / \mathrm{min}$ ) (Public Health Service, 1962). Based on the AEC estimate of $160 \mathrm{gpm}(610 \mathrm{~L} / \mathrm{min})$ pond seepage losses less the Public Health Service estimate of $50 \mathrm{gpm}(200 \mathrm{~L} / \mathrm{min})$ seepage that reached land surface, approximately $110 \mathrm{gpm}(420 \mathrm{~L} / \mathrm{min})$ remained in the underlying rock. Between 1954 and 1968 , this $110 \mathrm{gpm}(420 \mathrm{~L} / \mathrm{min})$ totals approximately 2500 acre-feet 
(3.1 million $\left.\mathrm{m}^{3}\right)$ yielding an average rate of 180 acre-feet $\left(220,000 \mathrm{~m}^{3}\right)$ per year, if the quantities were relatively constant over this time period.

No data have been found on the water quality in the evaporation ponds except that the water pumped to the ponds was at a pH of 2 (Public Health Service, 1962). A limited amount of water quality data was obtained in 1960 from the seeps and from Bob Lee Wash. A 1960 Public Health Service study indicated that cooling water radioactivity levels measured in Bob Lee Wash were comparable to radioactivity levels measured in the evaporation ponds, but the cooling water showed lower values for TDS (Public Health Service, 1962). The water in Bob Lee Wash, when sampled in 1960, may have been high in TDS due to the dissolution of solids deposited in the wash when a pond embankment failed that summer.

The seeps sampled nearest the ponds had the highest chemical concentrations. TDS was not measured, but sulfates of $3900 \mathrm{mg} / \mathrm{L}$ were observed along with total hardness (as calcium carbonate) of $10,800 \mathrm{mg} / \mathrm{L}$; nitrate concentrations of 1400 to $1600 \mathrm{mg} / \mathrm{L}$; and estimates of TDS of 9,000 to $12,000 \mathrm{mg} / \mathrm{L}$. The water quality from the seeps varied in quality, with these being among the highest values found.

\subsubsection{Surface remedial action and ground water protection strategy}

Between 1984 and 1986, the tailings were stabilized permanently on the site by consolidating the tailings and associated contaminated soils into a recontoured pile. The final cover at Shiprock consists of a 7-ft (2-m)-thick compacted clay layer that serves as a barrier to radon emanation and water infiltration. The clay layer is covered with a riprap cap designed to provide erosion protection for the effective life of the cell, up to 1000 years (DOE, 1985). The disposal cell covers about 76 ac ( 31 ha) (Thiers, 1986). A security fence encloses the embankment. No ground water protection strategy was determined for the Shiprock disposal site because the RAP was agreed to prior to the proposed EPA ground water standards (52 FR 36000 (1987)).

\subsection{SOURCES OF EXISTING DATA}

Beginning in 1982 and continuing to the present, surface and ground water characterization studies have been conducted at the processing site by the following contractors: Ford, Bacon, \& Davis, Inc. (FBDU, 1981); Geochemistry and Environmental Chemistry Research, Inc. (GECR, 1982); Dames and Moore (1982); Colorado State University (CSU, 1982); and the current DOE Technical Assistance Contractor (TAC), Jacobs Engineering Group Inc. Approximately 60 monitor wells have been installed and sampled on and around the site throughout the history of characterization. Surface water and sediment samples were taken from the San Juan River upstream, downstream, and adjacent to the site. The above references, site-specific data sets, and all TAC documents are on file in the UMTRA Project Document Control Center in Albuquerque, 
New Mexico. Much of the data referred to in this document will be included in Revision 1 of the SOWP along with the data being recommended for collection.

\subsection{CONCEPTUAL SITE MODEL}

The conceptual site model summarizes the effects of milling activities on the environment, the properties of the aquifer, general geology, ground water solute sources and sinks, and transport processes that take place in the aquifer near the site. This model identifies site-specific information and data gaps so that compliance strategies may be clearly identified, remediation technologies recommended, and additional data collection efforts defined.

\subsubsection{Hydrogeologic setting}

The Shiprock site consists of two distinct, hydrogeologic systems (Figure 3.4). These two systems, the terrace and the floodplain, are characterized by similar lithologies, but contrasting ground water flow systems and contaminant distributions.

\section{Regional hydrogeologic setting}

Because of low precipitation and high evaporation rates in the region, very little recharge to unconfined shallow aquifers occurs from surface precipitation events (DOE, 1991; NMBMMR, 1983). Annual rainfall averages 6.4 inches $(16 \mathrm{~cm})$, and pan evaporation rates have been measured at an average annual rate of 65 inches $(165 \mathrm{~cm})(D O E, 1984)$. Unconfined shallow aquifers within the hydrogeologic region of the site exist primarily due to recharge from rivers. The small amount of natural recharge to the terrace system is entirely from precipitation and the floodplain system is recharged primarily by the San Juan River.

In general, the geologic profile of the region consists of alluvial deposits of Quaternary age. The alluvial deposits overlie Cretaceous age Mancos Shale. Underlying the Mancos Shale is the Cretaceous age Dakota Sandstone and the Jurassic age Morrison Formation.

Ground water occurs under confining conditions in the Dakota Sandstone and Morrison Formation. A free-flowing artesian well constructed in 1955 near the site is reportedly completed in the Morrison Formation from approximately 1500 to $1900 \mathrm{ft}(460$ to $580 \mathrm{~m}$ ) below land surface (McLean and Johnson, 1987). The free-flowing condition, approximately $60 \mathrm{gpm}(200 \mathrm{~L} / \mathrm{min})$, demonstrates that the piezometric surface in the Morrison Formation is higher than the water table in the terrace or floodplain aquifers. This higher pressure head, combined with confinement of the aquifer by the Mancos Shale, will preclude movement of impacted water beneath the disposal cell into the deeper aquifers. This flowing well is discharging into Bob Lee Wash. 


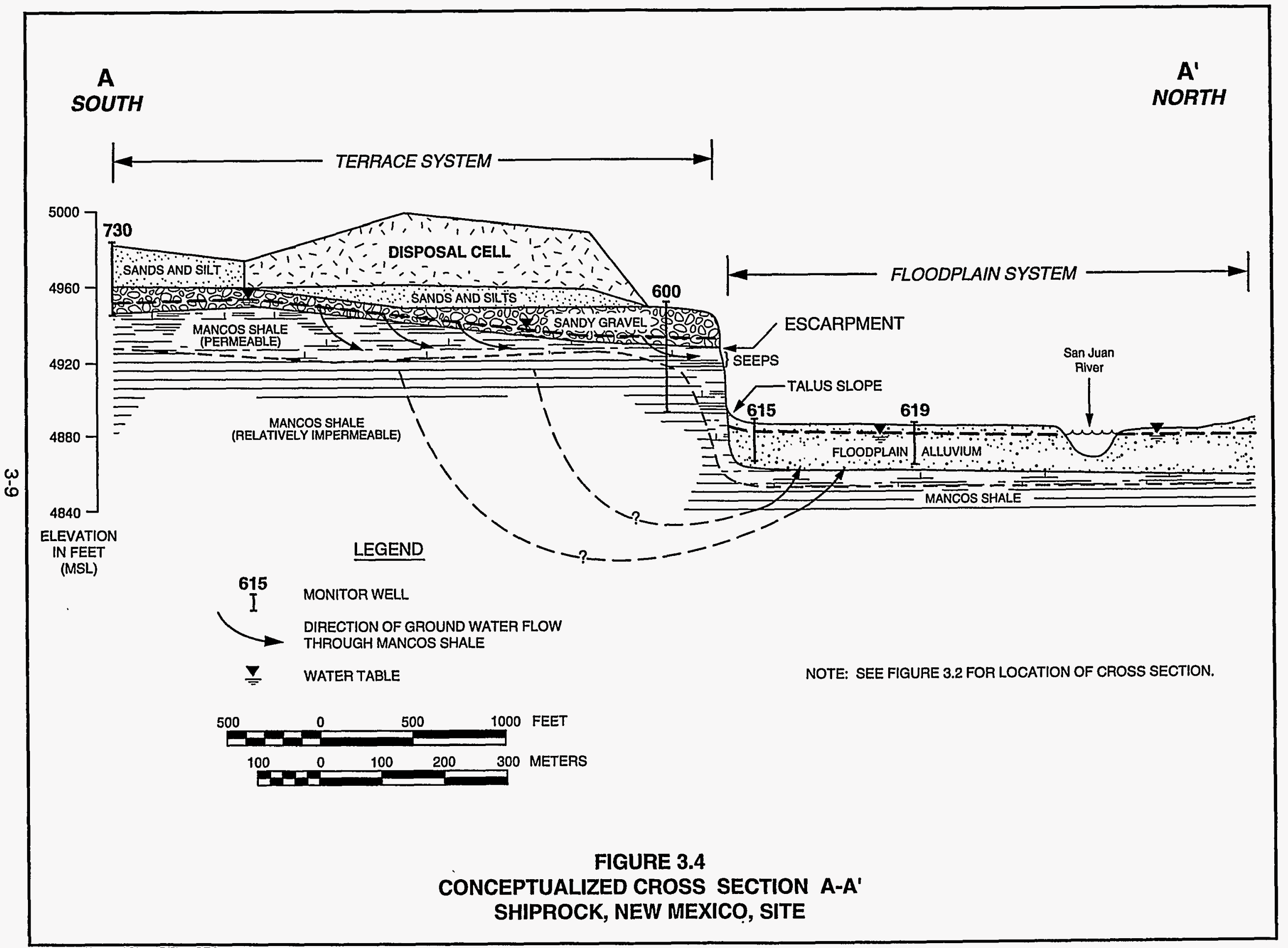




\section{Terrace hydrogeologic system}

The terrace hydrogeologic system comprises the following components:

- Prior to milling operations, an insignificant perched ground water system most likely existed along an alluvium-Mancos Shale interface within the elevated terrace. Based on the climatic data mentioned above, this system receives a negligible amount of recharge from direct precipitation.

- As a result of milling operations, an estimated 840 million gal ( 3200 million $L$ ) of water was discharged into the terrace system, producing a significant ground water mound above the alluvium-Mancos Shale interface underlying the former mill site (TAC, 1995).

- Water in the ground water mound could have flowed away from the mound in a radial pattern when the mound was high during active use of the ponds on the terrace. As the mound diminished with the mill closing, ground water flow from the mound would have been primarily limited to the west and northwest along the direction of dip of the top of the Mancos Shale, and toward the floodplain through fractures in the Mancos Shale.

- Currently, it appears that water in the terrace aquifer discharges primarily to the floodplain system through seeps on the escarpment and possibly through fractures in the Mancos Shale, and that this flow is less now than it was at the peak of the mill operations. This flow is expected to diminish further because the only recharge to the terrace aquifer is from precipitation, which is negligible.

The terrace hydrogeologic system components are supported by the detailed discussion below.

The elevated terrace at the Shiprock site is capped by alluvial deposits of Quaternary age ranging in thickness from 10 to $45 \mathrm{ft}(3$ to $14 \mathrm{~m})$. These deposits consist of interbedded sands and silts with numerous lenses of gravel and cobbles. The alluvial terrace deposits overlie the Cretaceous age Mancos Shale (Figure 3.4).

The Mancos Shale in the vicinity of the Shiprock site typically consists of horizontally bedded shales and sandy shales and is approximately $1000 \mathrm{ft}$ $(300 \mathrm{~m})$ thick. The upper 10 to $30 \mathrm{ft}(3$ to $9 \mathrm{~m})$ of the Mancos Shale is highly weathered and fractured with low strength. Below this weathered zone, the shale is more competent and relatively impermeable.

The upper surface of the Mancos Shale exhibits erosional effects from the ancestral San Juan River. A structure map of the top of the Mancos Shale (Figure 3.5) shows erosional swales and ridges characteristic of meandering fluvial systems. These swales (paleochannels) and ridges are oriented approximately east-west along the ancestral San Juan River drainage underlying 


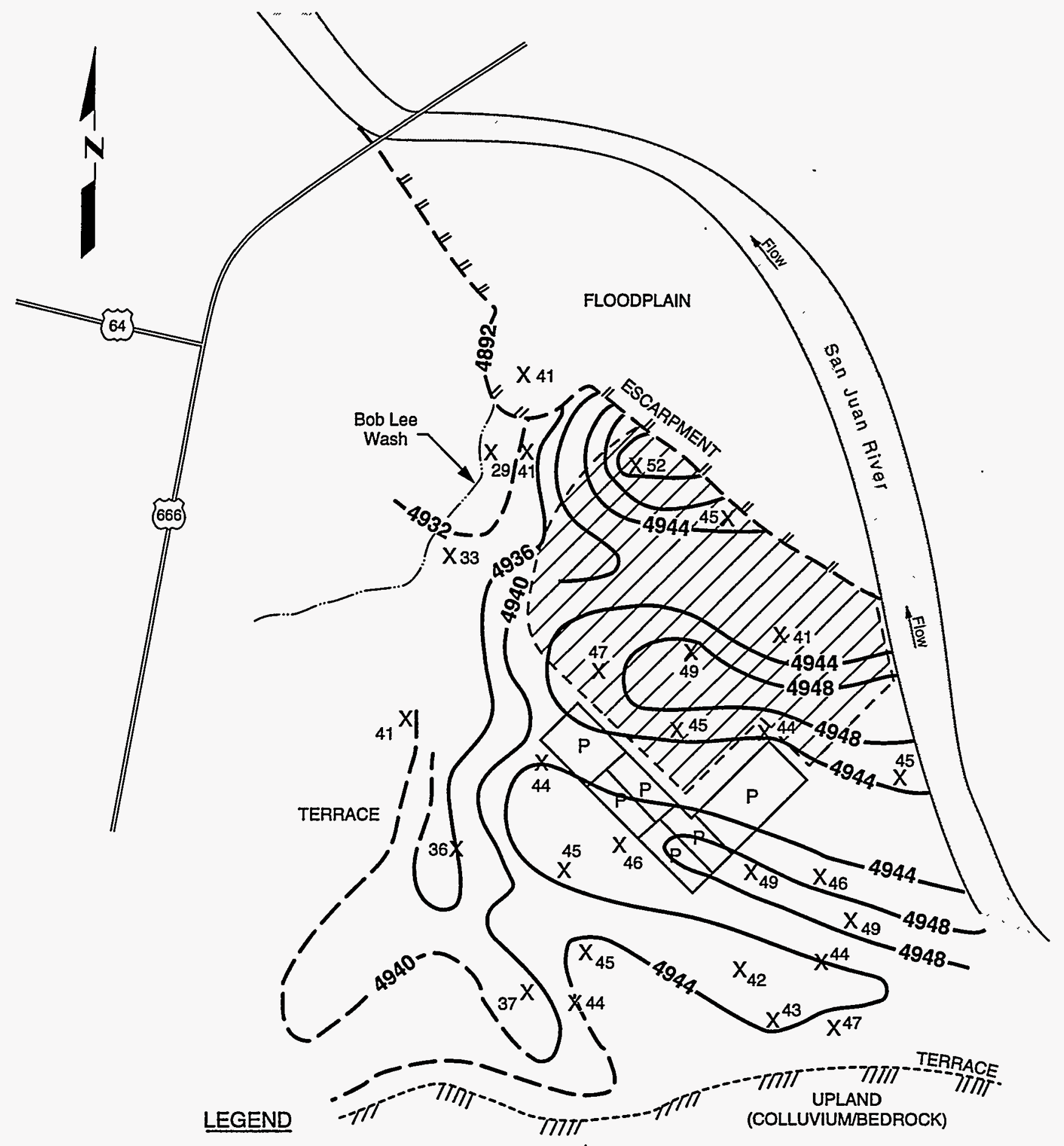

-4892 BEDROCK SURFACE CONTOUR (FT ABOVE MSL,

DASHED WHERE INFERRED,

ESTIMATED FROM LIMITED DATA)

${ }^{41} \mathrm{X}$ BEDROCK ELEVATION IN

BORING (+4900 FT ABOVE MSL)

"DID FORMER TAILINGS PILES AND MILLSITE

$\mathrm{P}$ FORMER RAFFINATE POND

\begin{tabular}{|c|c|c|c|c|}
\hline 500 & 0 & 500 & 1000 & FEET \\
\hline & & 15 & 30 & ERS \\
\hline
\end{tabular}

- EPHEMERAL STREAM

666 U.S. HIGHWYY FIGURE 3.5

BEDROCK SURFACE CONTOURS ON TERRACE SHIPROCK, NEW MEXICO, SITE 
the disposal cell and former mill site.

The ground water in the terrace alluvium and the upper part of the Mancos Shale is unconfined. Based on the low yield of ground water from monitor wells on the terrace, there appears to be a very small amount of ground water within the terrace alluvium and in the upper, weathered part of the Mancos Shale.

Most of the water in the terrace alluvium in the site vicinity is believed to have been derived from the former milling operations and tailings piles. The ponds active during the milling operations (Figure 3.3) reportedly lost approximately 7 million gal (26 million L) per month (Gilkey and Stotelmeyer, 1965). Of this amount, 5 million gal (19 million $L$ ) per month of process water is estimated to have remained in the terrace formation (Public Health Service, 1962). This amount of water is likely to have formed a considerable ground water mound perched on the Mancos Shale. During construction, San Juan River water was used for dust control at and around the construction area (including on the tailings), for compaction of tailings relocated on the site, and for construction of the compacted clay cover placed over the compacted tailings. No dust control water was assumed to have entered the stabilized pile because this water was placed only on the surface of the tailings to keep it damp, thus preventing the wind from blowing dust off the pile. Most of this water was assumed to have evaporated after placement. Construction water used during the placement of the clay cover also was assumed to have not entered the stabilized pile because the clay material used for the cover will not release this water. Because the pile was essentially stabilized in place, most of the tailings did not have construction water added for compaction during construction. Based on the above assumptions, little of the construction water used at the Shiprock site is believed to have entered the pile and is available for percolation through the pile and infiltration into the underlying pile foundation. Seepage infiltrating the alluvium would move across the shale surface in all directions and infiltrate the upper, weathered zone of the Mancos. As the size of the mound diminished after the milling operations ceased, the movement of the perched ground water would be controlled for the most part by the erosional topography of the top of the Mancos Shale and by fractures in the Mancos Shale.

The erosional topography (Figure 3.5) would likely cause perched ground water, derived from the ground water mound, to flow west-northwest in addition to flowing north and northeast toward the San Juan River. The documentation of seeps on the escarpment during milling operations in the region where swales were truncated by the escarpment supports the theory of paleochannel control on contaminant migration.

Some of the ground water in the terrace alluvium may also percolate down into the upper, fractured part of the Mancos Shale. This water moves horizontally along bedding planes and can be seen seeping from bedding planes in the shale along the escarpment face immediately north of the disposal cell. It is possible that a small component of flow enters the deeper Mancos Shale and flows through fractures toward the San Juan River. This water then moves from the Mancos Shale into the overlying floodplain alluvium (Figure 3.41. Evidence of 
this discharge from the Mancos Shale into the alluvium has been observed in floodplain monitor wells completed in the Mancos Shale. Monitor wells in the Mancos Shale appear to show a higher pressure head relative to those completed in the overlying floodplain alluvium.

\section{Floodplain hydrogeologic system}

The floodplain hydrogeologic system comprises the following components:

- The recent alluvial materials of the floodplain system were deposited on an eroded Mancos Shale surface. The deposits are typical of floodplains in such environments. They vary from coarse gravel and cobbles found in high-energy channels, to fine uniform sands indicative of point bars, to silty sediments typical of quiet backwater areas.

- The surface of the Mancos Shale underlying the floodplain deposits is characterized by parallel meander scars (scour channels) typical of a lateral migrating meander process. These scour channels are at a lower elevation than the base of the San Juan River channel.

- The floodplain alluvium is characterized by sand and silt deposits with some gravel overlain by coarser-grained gravel and cobble deposits that contain some sand. The finer-grained deposits range in thickness from about 1 to $13 \mathrm{ft}(0.3$ to $4 \mathrm{~m})$. The coarser-grained deposits range in thickness from about 5 to $19 \mathrm{ft}(1.5$ to $5.8 \mathrm{~m})$. These deposits are cut by a series of recent meander scars.

- The primary source of ground water recharge to the floodplain system is from the San Juan River. Secondary sources include 1) the artesian well discharging to Bob Lee Wash, 2) escarpment seeps discharging from the upper weathered Mancos section of the terrace system (along bedding planes and fractures), 3) precipitation, and 4) possible fracture flow from the Mancos Shale beneath the floodplain alluvium.

- The lithologic and structural heterogeneity of the floodplain system suggests there are vertical and horizontal variations in the hydraulic conductivity of the system. Ground water flow paths and velocities would be affected by these variations.

- Structural depressions on the top of the Mancos Shale (the scour channels) produced by the lateral meander process may result in ground water that is stagnant relative to the ground water flow in the upper alluvium, which is unimpeded by the structural surface of the Mancos Shale. Higher density water (water with high TDS) would tend to settle in these depressions where flow velocities may be slower than that of the shallower ground water. Associated constituents in the high TDS water would also be trapped in these depressions. 
The floodplain hydrogeologic conceptual model components are supported by the detailed discussion below.

North and east of the disposal cell is the floodplain system of the San Juan River (Figure 3.2). The floodplain consists of unconsolidated alluvial material ranging in size from cobbles to clay size particles. The Mancos Shale underlies the floodplain alluvium at an average depth of approximately $15 \mathrm{ft}(4.6 \mathrm{~m})$ (Figure 3.4). The floodplain deposits are limited in their areal extent. The deposits are bounded to the west and south by the 50-ft (15-m)-high Mancos Shale escarpment. The floodplain is bounded to the east and north by the San Juan River.

A structure map for the top of the Mancos Shale where it underlies the floodplain alluvial deposits is shown in Figure 3.6. Available data are restricted to the southern portion of the floodplain. The map depicts a series of ridges and swales, parallel to subparallel to the San Juan River. This morphology (parallel meander scars) is the typical result of the lateral meander migration process of the San Juan River.

Lithologic data from boreholes and monitor wells were used to define two distinct units within the recent alluvial deposits. They consist of an upper unit containing interbedded gravel to silty clays, and a lower, relatively coarsergrained, poorly sorted unit containing gravel to cobble size material. This reflects the characteristic sequence of grain size (fining upward) and sedimentary structures typically associated with a point bar sequence. Figure 3.7 is a fence diagram depicting in part the stratigraphic relationships within the floodplain deposits.

The floodplain contains a shallow unconfined ground water system. It is recharged primarily by water from the San Juan River that enters the floodplain at its upstream end, approximately $1000 \mathrm{ft}(300 \mathrm{~m})$ east of the tailings pile. Additional recharge comes from the flowing well at Bob Lee Wash, from the seeps along the escarpment, and from precipitation. The floodplain system is possibly a local discharge source for the underlying Mancos Shale. The ground water in the floodplain then discharges back to the river along the downstream half (northern end) of the floodplain. A water table map of the floodplain is shown in Figure 3.8.

Some ground water in the floodplain enters a drainage ditch that separates the northwestern third of the floodplain. This ditch follows a preexisting natural meander channel in the floodplain (Figure 3.3) but appears to have been artificially deepened. During periods of high river flow and/or heavy precipitation, the water table intersects this ditch. Some ground water flow is diverted into the ditch, which discharges to the river at the extreme northwestern end of the floodplain. During low river flow periods, however, the ditch is dry and the water table is beneath the bottom of the ditch. 


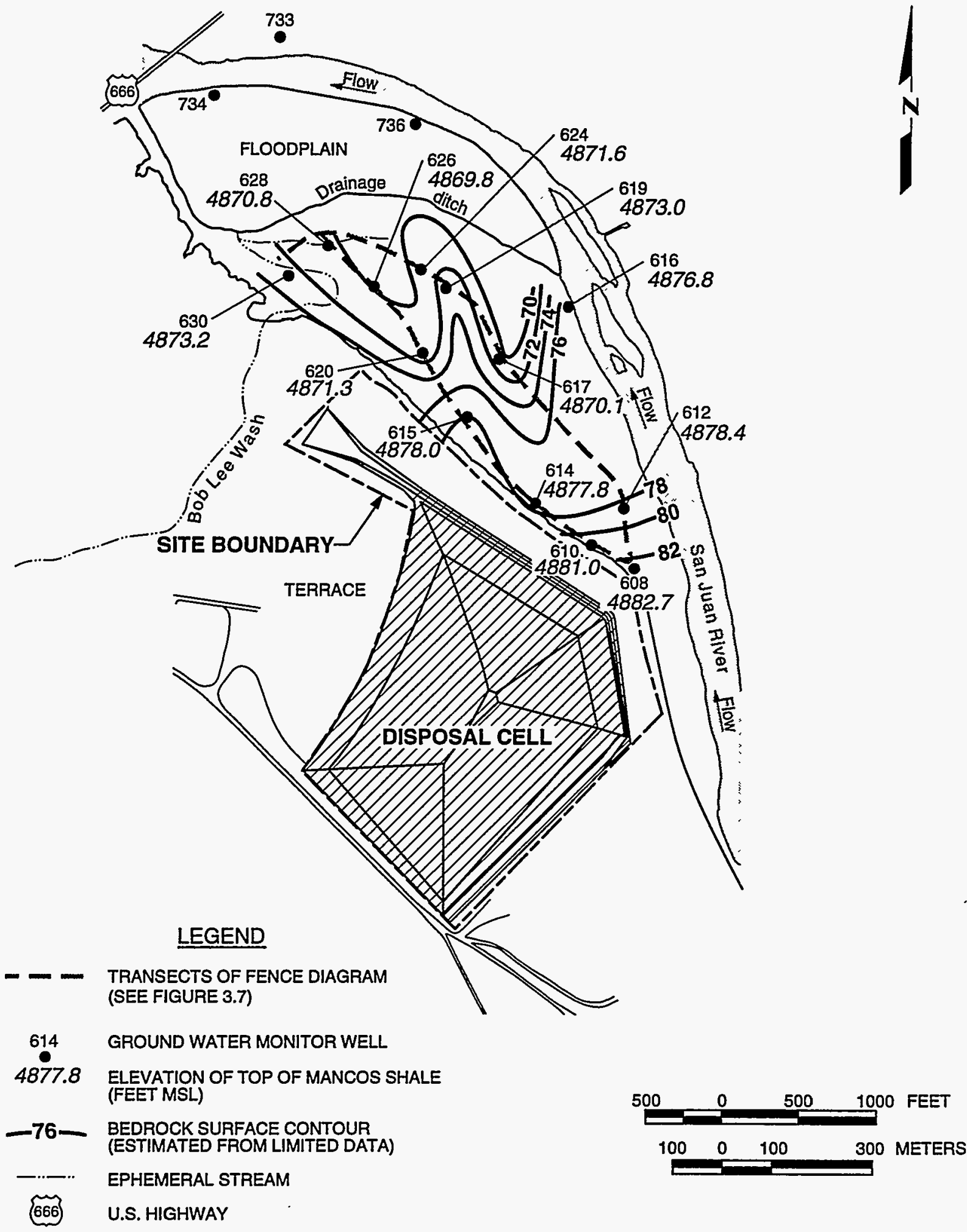

FIGURE 3.6

BEDROCK SURFACE CONTOURS ON FLOODPLAIN SHIPROCK, NEW MEXICO, SITE 


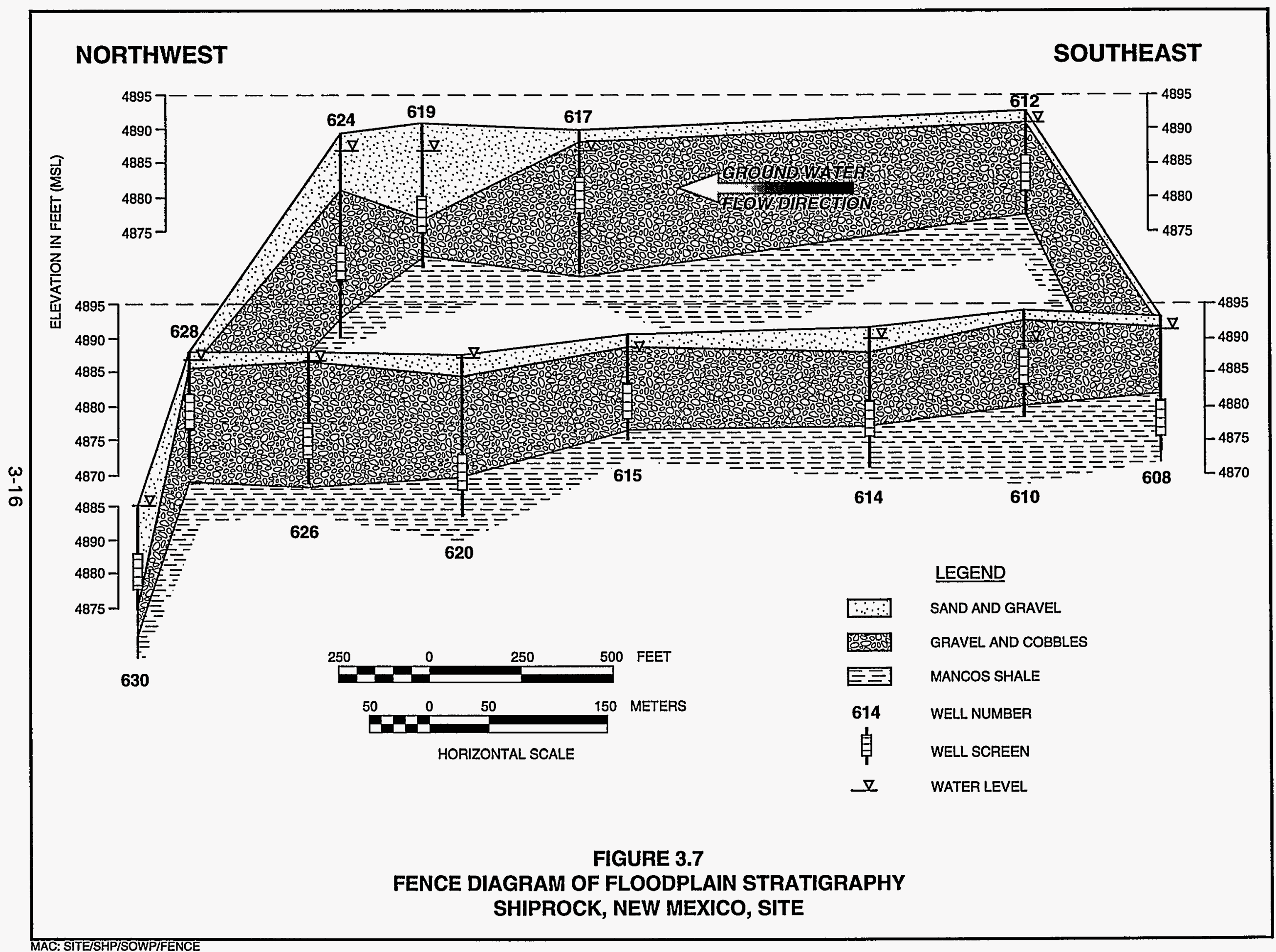




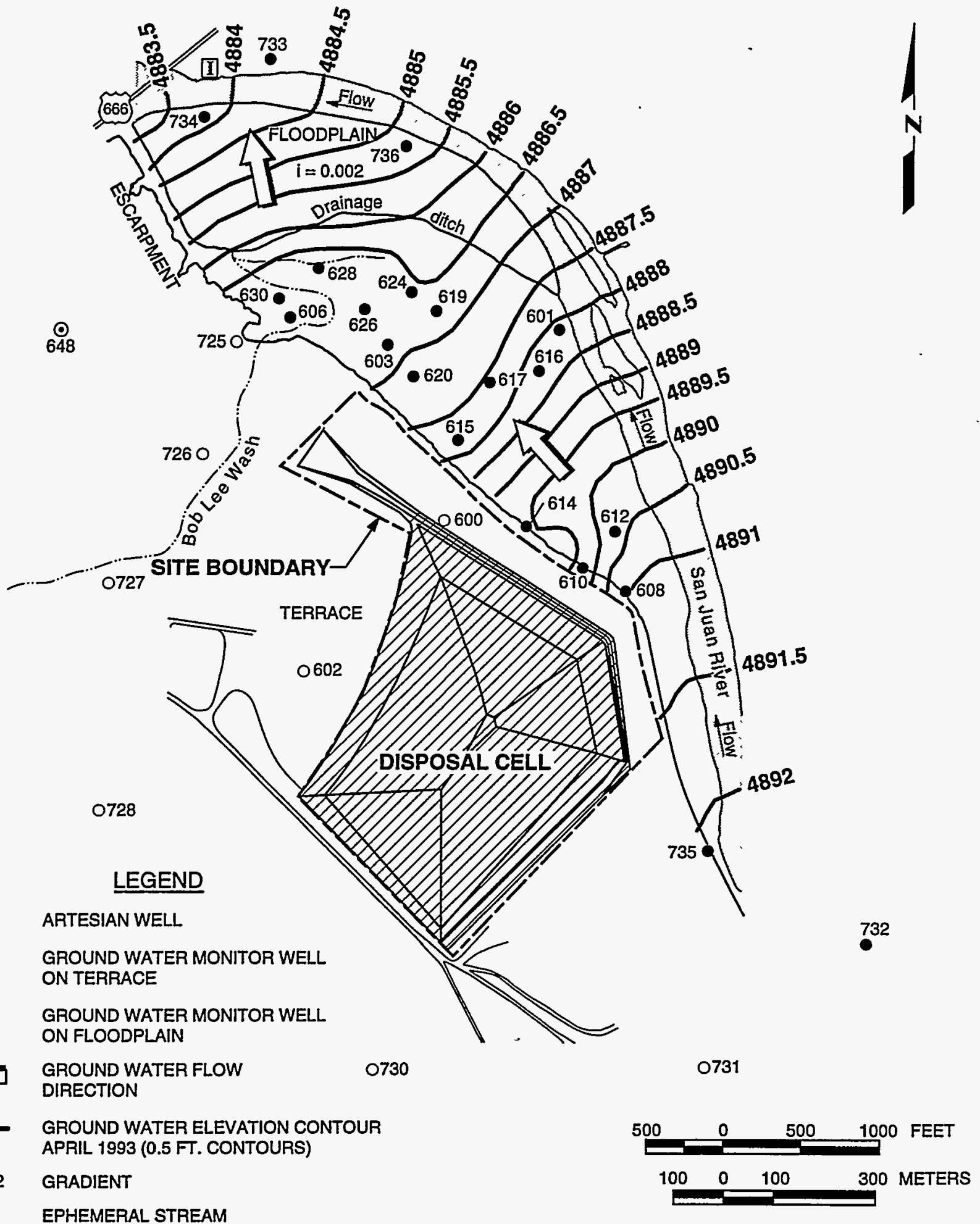
$\odot 648$ ARTESIAN WELL
O 730 GROUND WATER MONITOR WELL ON TERRACE
- 612 GROUND WATER MONITOR WELL ON FLOODPLAIN

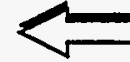
GROUND WATER FLOW
4887- GROUND WATER ELEVATION CONTOUR
APRIL 1993 (0.5 FT. CONTOURS)
$i=0.002$ GRADIENT
E...". EPHEMERAL STREAM
[ WATER INTAKE STATION

FIGURE 3.8

NOTE: WATER LEVELS FOR SAN JUAN RIVER ARE ASSUMED FROM GROUND WATER - MONITOR WELL DATA.

\section{GROUND WATER TABLE CONTOURS AND GRADIENT ON FLOODPLAIN SHIPROCK, NEW MEXICO, SITE}


Water level data from the river and from monitor wells on the floodplain near the river show that water levels between the river and the floodplain aquifer are very close. This indicates that there is a direct connection between water in the river and ground water in the floodplain aquifer, which suggests that it is unlikely that ground water flows from the aquifer on the southwest side of the river to the aquifer on the northeast side of the river.

Visual inspection of the alluvial deposits and comparisons with typical ranges of hydraulic conductivity described in the literature (Hunt, 1984) suggest that the hydraulic conductivity could vary by 2 orders of magnitude, from less than 5 feet per day ( $\mathrm{ft} /$ day) $(0.001$ centimeters per second $[\mathrm{cm} / \mathrm{s}])$ to more than $300 \mathrm{ft} / \mathrm{day}(0.1 \mathrm{~cm} / \mathrm{s})$. The sediments encountered during installation of monitor wells 734 and 736 (Figure 3.8), where ground water discharges from the floodplain into the San Juan River, were relatively uniform, medium-grained sands. Because the hydraulic conductivity of these sediments will control the discharge rate of impacted water to the San Juan River, an intermediate hydraulic conductivity typical of such sediments (approximately $30 \mathrm{ft} / \mathrm{day}$ $[0.01 \mathrm{~cm} / \mathrm{s}]$ ) (Freeze and Cherry, 1979) will be used in this study until further data-gathering efforts show otherwise. The hydraulic gradient across the floodplain is approximately 0.002 .

An average ground water discharge of about $6 \mathrm{gpm}(20 \mathrm{~L} / \mathrm{min})$ is calculated based on a hydraulic conductivity of $30 \mathrm{ft} / \mathrm{day}(0.01 \mathrm{~cm} / \mathrm{s})$, a hydraulic gradient of 0.002 , and an estimated cross-sectional area of discharge of about 20,000 square feet (2000 square meters) along the southern bank of the San Juan River. This cross-sectional area is based on a depth of the river of about 8 $\mathrm{ft}(2.4 \mathrm{~m})$ and a length of $2500 \mathrm{ft}(760 \mathrm{~m})$ where the water level elevations show discharge from the floodplain aquifer to the river.

\section{Surface water}

The San Juan River forms the eastern and northern boundaries of the floodplain. Surface runoff from northwest and west of the disposal cell flows into Bob Lee Wash, which discharges onto the floodplain. Bob Lee Wash also receives a constant discharge of approximately $60 \mathrm{gpm}(200 \mathrm{~L} / \mathrm{min})$ from an artesian well (648) located west of the wash (Figure 3.9). Discharge from this well flows down Bob Lee Wash and discharges into a swampy area on the floodplain. This water eventually flows into a drainage channel that cuts across the floodplain and joins the San Juan River approximately $0.5 \mathrm{mi}(0.8 \mathrm{~km})$ northwest of the disposal cell. Surface runoff east of the tailings pile either flows into a borrow area east of the site and then down the escarpment onto the floodplain or it reaches Many Devils Wash, which discharges into the San Juan River approximately $0.5 \mathrm{mi}(0.8 \mathrm{~km})$ east of the cell.

Three unnamed arroyos that cut the escarpment above the floodplain can be seen in the aerial photograph (Figure 3.3 ) taken before site cleanup. These 


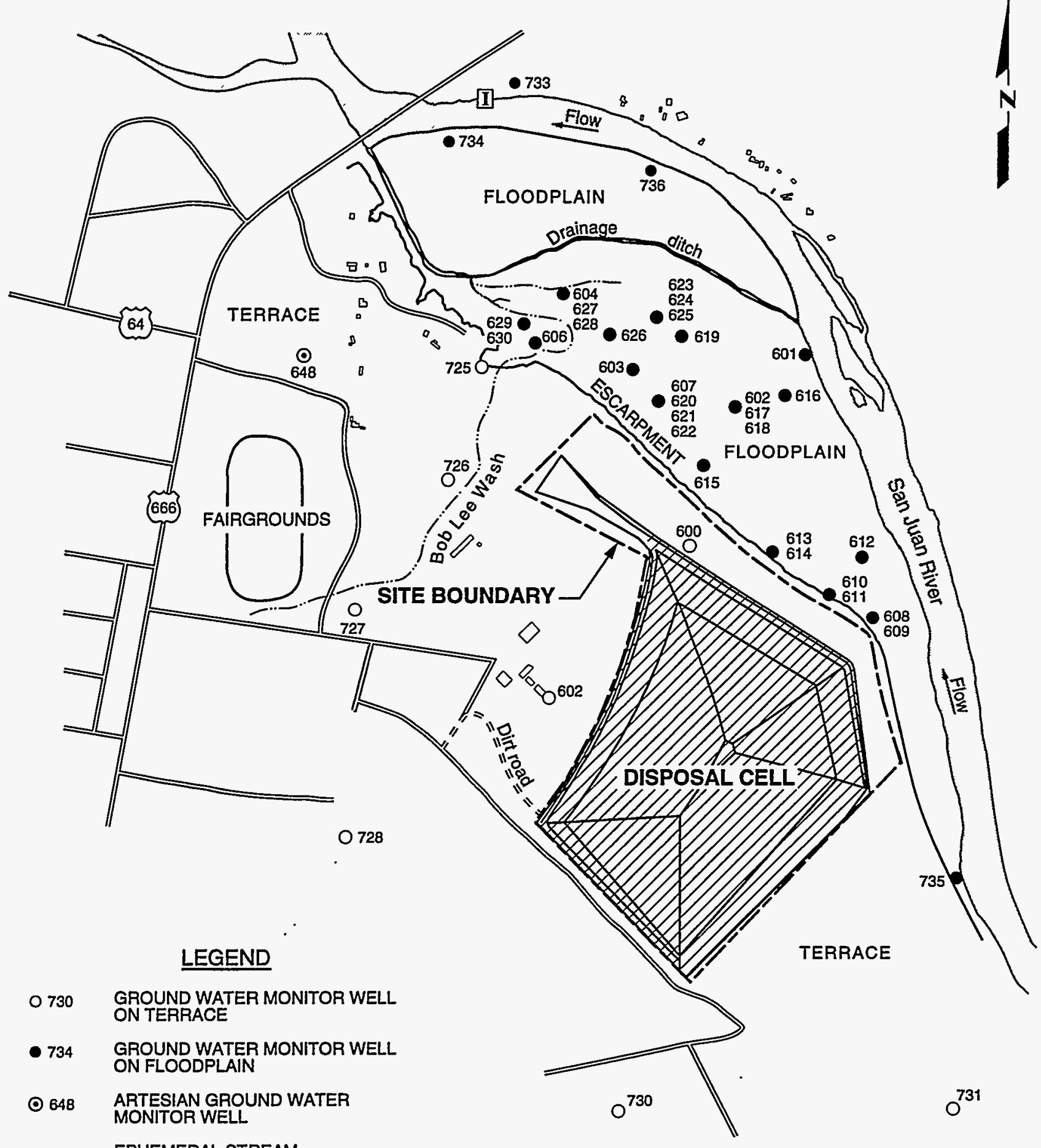

$\begin{array}{cl}\text {-.w } & \text { EPHEMERAL STREAM } \\ 666 & \text { U.S. HIGHWAY } \\ \therefore \square & \text { RESIDENTIAL } \\ \square & \text { MILL BUILDING } \\ \square & \text { WATER INTAKE STATION }\end{array}$

\section{FIGURE 3.9 \\ GROUND WATER MONITOR WELL LOCATIONS SHIPROCK, NEW MEXICO, SITE}


arroyos were filled during the surface restoration activities at the site. According to a 1977 letter (Hans, 1977), seeps were identified and sampled in these arroyos.

In 1990, two seeps were identified originating from the escarpment of Mancos Shale (Figure 3.10). One seep (425) is located on the escarpment about $15 \mathrm{ft}$ $(4.6 \mathrm{~m})$ above the floodplain near the northern corner of the disposal cell. This seep is about $30 \mathrm{ft}(9 \mathrm{~m})$ long and consists of a series of drips under an overhanging, indurated sand lens within the Mancos Shale. The flow rate from the seepage face was approximately $0.5 \mathrm{gpm}(2 \mathrm{~L} / \mathrm{min})$ in January 1991 (DOE, 1991). The second seep ( 426 ) is located southeast of where Bob Lee Wash enters the San Juan River floodplain. This seep is approximately $5 \mathrm{ft}(2 \mathrm{~m})$ above the floodplain and flowed at a rate of about $1 \mathrm{gpm}(4 \mathrm{~L} / \mathrm{min})$ in January 1991.

\subsubsection{Ground and surface water quality}

Water quality data were collected from 1984 to 1993 from monitor wells and surface locations at the Shiprock site. At present, 8 monitor wells are located on the terrace, 23 monitor wells and 9 well points are located on the floodplain, and $\mathbf{2}$ monitor wells are located on the opposite bank of the San Juan River (see Table 3.11. The current surface water monitoring network at the Shiprock site consists of nine locations along the San Juan River, three locations along the drainage ditch, five locations on the alluvial floodplain, three locations along Bob Lee Wash, and two seeps at the base of the escarpment. Water quality samples have also been collected from the artesian well (648) west of Bob Lee Wash, which is completed in the underlying regional aquifer in the Morrison Formation. Monitor wells and surface sampling locations are shown in Figures 3.9 and 3.10, respectively. The existing UMTRA Project water quality data base for the Shiprock site consists of both filtered and unfiltered samples.

\section{Background water quality summary}

Background water quality is defined as the quality of water if uranium milling activities had not taken place and is discussed for both the terrace and floodplain aquifers.

Terrace system - Water quality data and well recovery data from wells in the vicinity of the processing site suggest that ground water in the terrace alluvium is derived mostly from the milling process and related activities. None of the ground water sampled from the monitor wells installed on the terrace can be considered representative of background conditions. Therefore, background ground water quality cannot be defined in the region immediately adjacent to the disposal cell.

Floodplain system - Analysis of geochemical data indicates that ground water in the floodplain aquifer below the terrace has been degraded by milling activities. Therefore, data from ground water in this area cannot be used to 


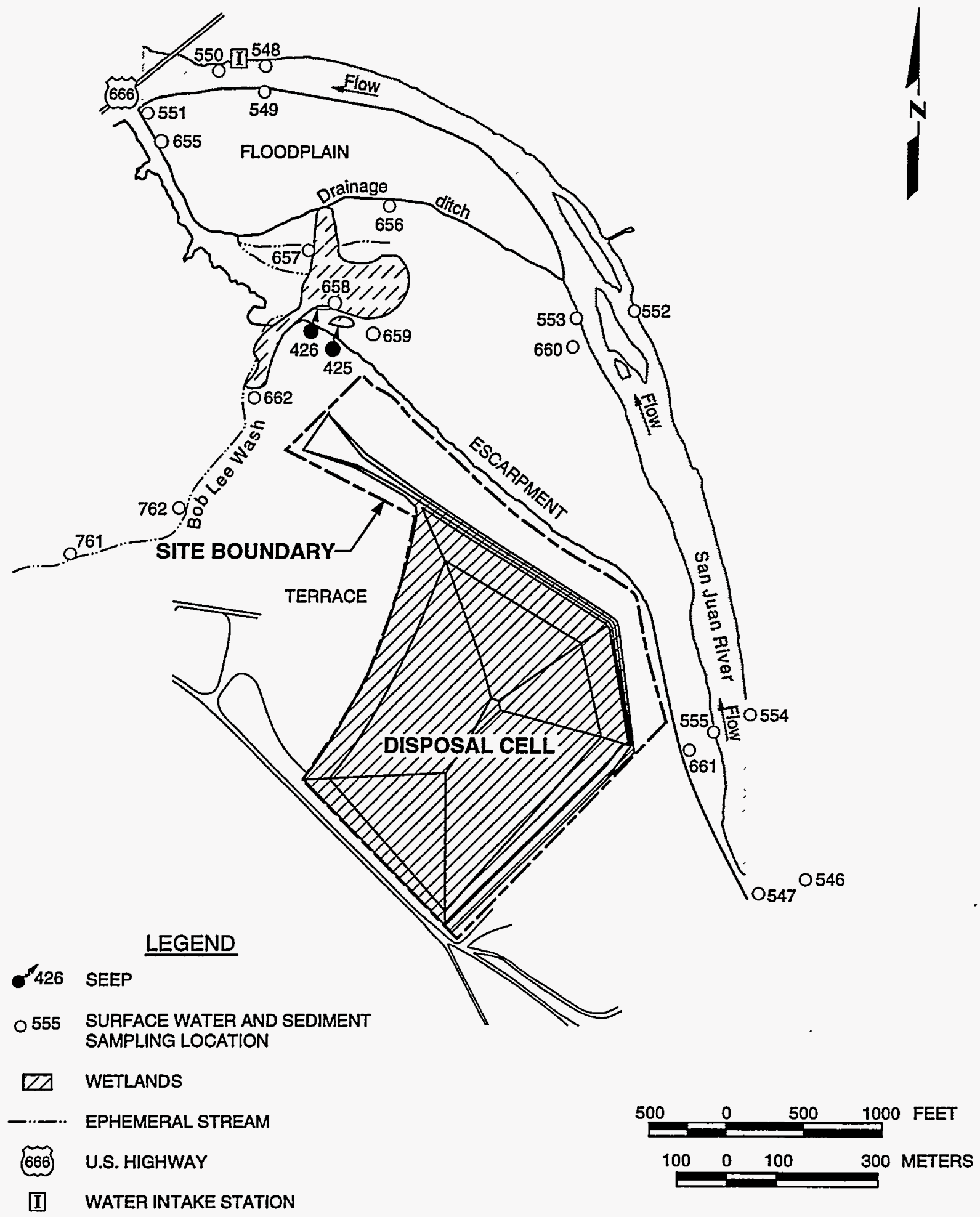

FIGURE 3.10

LOCATIONS OF FLOODPLAIN SURFACE WATER AND SEDIMENT SAMPLING STATIONS ADJACENT TO SHIPROCK TAILINGS SITE SHIPROCK, NEW MEXICO, SITE 


\begin{tabular}{|c|c|c|c|c|c|c|c|c|c|c|c|c|c|c|}
\hline \multirow{9}{*}{ 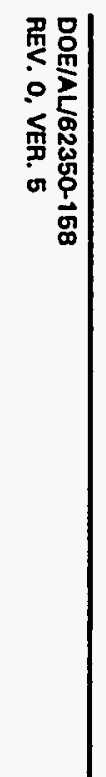 } & \multicolumn{14}{|c|}{ Table 3.1 Monitor well information, Shiprock, New Mexico, site } \\
\hline & $\begin{array}{c}\text { Woll } \\
\text { number }\end{array}$ & Location & $\begin{array}{l}\text { Date of } \\
\text { inatallation }\end{array}$ & $\begin{array}{c}\begin{array}{c}\text { North } \\
\text { coordinate } \\
\text { (ft) }\end{array} \\
\end{array}$ & $\begin{array}{c}\text { East } \\
\text { coordinato } \\
\text { (ft) }\end{array}$ & $\begin{array}{c}\text { Ground } \\
\text { elevation } \\
\text { (ft MSLI) }\end{array}$ & $\begin{array}{l}\text { Casing } \\
\text { elevation } \\
\text { (ft MSL) } \\
\end{array}$ & $\begin{array}{c}\text { Boreholo } \\
\text { depth } \\
\text { (ft) }\end{array}$ & $\begin{array}{l}\text { Borehole } \\
\text { diameter } \\
\text { (inches) }\end{array}$ & $\begin{array}{c}\text { Casing } \\
\text { longth } \\
\text { (ft) }\end{array}$ & $\begin{array}{c}\text { Caoing } \\
\text { diamoter } \\
\text { (inchee) }\end{array}$ & $\begin{array}{c}\text { Screen } \\
\text { beginning } \\
\text { depth } \\
\text { (t) }\end{array}$ & $\begin{array}{c}\text { Screon } \\
\text { longth } \\
\text { (ft) }\end{array}$ & $\begin{array}{c}\text { Depth to } \\
\text { top of } \\
\text { filter } \\
\text { pack } \\
\text { (fit) } \\
\end{array}$ \\
\hline & $600^{\circ}$ & $T$ & $1981-82$ & 9198.70 & 10761.00 & 4957.45 & NA & 62.7 & 6.75 & 48.8 & 4.00 & 29.00 & 19.8 & NA \\
\hline & $602^{b}$ & $T$ & $1981-82$ & 8090.30 & 9851.80 & 4956.87 & NA & 96.7 & 6.75 & 47.0 & 4.00 & 27.00 & 20.0 & 23.0 \\
\hline & 602 & FP & $9 / 29 / 84$ & 10140.00 & 10850.00 & 4890.00 & 4890.00 & 7.0 & 1.25 & 3.58 & 1.25 & 0.35 & 2.9 & NA \\
\hline & 603 & FP & $9 / 29 / 84$ & 10300.00 & 10200.00 & 4888.00 & 4888.00 & 5.0 & 1.25 & 3.58 & 1.25 & 1.35 & 1.9 & NA \\
\hline & 604 & FP & $9 / 29 / 84$ & 10720.00 & 9750.00 & 4888.00 & 4888.00 & 6.0 & 1.25 & 3.58 & 1.25 & 0.35 & 2.9 & NA \\
\hline & 606 & FP & $10 / 17 / 84$ & 10446.10 & 9550.50 & 4887.67 & 4888.57 & 5.3 & 1.25 & 5.30 & 1.25 & 2.65 & 2.3 & NA \\
\hline & 607 & FP & $10 / 17 / 84$ & 10160.00 & 10350.00 & 4888.00 & 4890.00 & 6.6 & 1.25 & 6.60 & 1.25 & 3.95 & 2.3 & NA \\
\hline & 611 & FP & $9 / 3 / 85$ & 8899.20 & 11429.70 & 4894.05 & 4896.29 & 16.5 & 8.75 & 18.50 & 4.00 & 11.50 & 5.0 & 7.0 \\
\hline & 612 & FP & $9 / 4 / 85$ & 9192.10 & 11665.70 & 4892.90 & 4894.85 & 12.0 & 8.75 & 14.00 & 4.00 & 7.00 & 5.0 & 3.5 \\
\hline & 613 & FP & $9 / 4 / 85$ & 9196.30 & 11047.90 & 4891.88 & 4894.63 & 12.0 & 8.75 & 14.00 & 4.00 & 7.00 & 5.0 & 3.5 \\
\hline & 614 & FP & $9 / 4 / 85$ & 9189.40 & 11058.00 & 4891.83 & 4895.03 & 17.0 & 8.75 & 19.00 & 4.00 & 12.00 & 5.0 & 8.0 \\
\hline & 615 & FP & $9 / 6 / 85$ & 9744.70 & 10667.30 & 4890.96 & 4893.17 & 11.5 & 8.75 & 13.50 & 4.00 & 6.50 & 5.0 & 3.5 \\
\hline & 616 & FP & $9 / 5 / 85$ & 10213.50 & 11140.80 & 4890.78 & 4893.17 & 12.0 & 8.75 & 14.00 & 4.00 & 7.00 & 5.0 & 3.5 \\
\hline & 617 & FP & $9 / 5 / 85$ & 10140.60 & 10862.40 & 4890.35 & 4892.67 & 12.0 & 8.75 & 14.00 & 4.00 & 7.00 & 5.0 & 3.5 \\
\hline & 618 & FP & $9 / 5 / 85$ & 10138.10 & 10849.30 & 4890.13 & 4892.55 & 18.0 & 8.75 & 20.00 & 4.00 & 13.00 & 5.0 & 9.0 \\
\hline & 619 & FP & $9 / 6 / 85$ & 10524.10 & 10501.50 & 4891.02 & 4892.99 & 15.0 & 8.75 & 17.00 & 4.00 & 10.00 & 5.0 & 6.0 \\
\hline$\frac{1}{8} \overrightarrow{0}$ & 620 & FP & $8 / 27 / 85$ & 10162.20 & 10344.00 & 4888.36 & 4890.40 & 20.0 & 8.75 & 21.80 & 4.00 & 14.80 & 5.0 & 11.0 \\
\hline
\end{tabular}




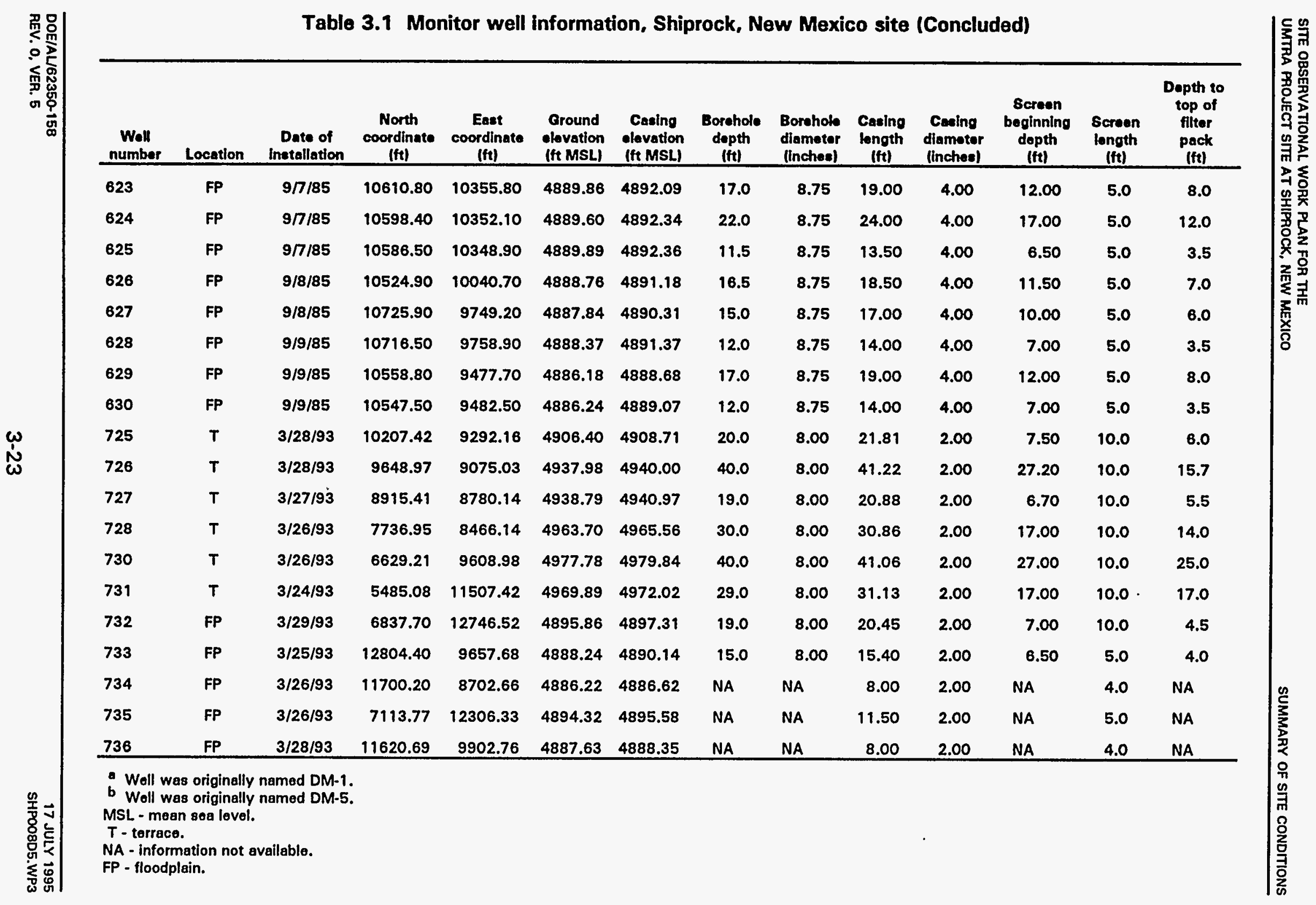


determine background conditions. Instead, background water quality is defined by monitor wells 732 and 733 completed in the alluvial system north and east of the San Juan River, respectively (Figure 3.9). Water quality data from two U.S. Geological Survey wells (SJ3, approximately 9 mi [14 km] upstream and G10, approximately $8 \mathrm{mi}[13 \mathrm{~km}$ ] downstream from the site) (Figure 3.11$]$ were used to compare ground water quality in the shallow alluvial system above and below the Shiprock site.

Background ground water can be described as a sulfate-bicarbonate, calciumsodium type with slightly basic $\mathrm{pH}$ and TDS ranging from 800 to $5000 \mathrm{mg} / \mathrm{L}$. Although variable, background ground water from monitor wells $732,733,634$, and 635 has a similar chemical composition and falls into the same general chemical field. Variability in water chemistry can be explained by 1) distance of the well from the river (TDS decrease away from the river), 2) depth of the well (TDS appear to decrease with depth due to the diminishing effect of evaporation with depth) and 3) fluctuating chemistry of the San Juan River (discussed below).

The San Juan River influences ground water quality adjacent to the river channel. The solute load of the river varies depending on the volume of flow in the river, the amount of water each tributary contributes to flow (since the water quality is affected by the differing geologic formations each tributary flows through), and the evaporation rate. Because of these effects, ground water chemistry is not homogeneous in the floodplain adjacent to the river. Sulfate/chloride ratios in background wells in the alluvial aquifer range from 16 to 37 , illustrating the variability in solute concentrations in this system. A statistical summary of select water quality data for the four alluvial wells used to determine background is shown in Table 3.2.

Magnitude and extent of site-related contamination

Uranium milling has impacted ground water in both the terrace and floodplain aquifers. Antimony, arsenic, cadmium, magnesium, manganese, nitrate, selenium, sodium, strontium, sulfate, and uranium were identified as contaminants of potential concern in the floodplain aquifer during the 1993 baseline risk assessment (DOE, 1994a). Because of their relative high concentrations, as compared to concentrations in the background ground water, uranium, nitrate, and sulfate were chosen as indicator parameters and used to describe the magnitude and extent of the plume.

Ground water at the Shiprock site has not been screened for organic contaminants. Because an organic-based solvent extraction process was used to recover uranium from the pregnant solution (Section 3.1), some kerosenederived organic compounds may be found in soils and ground water as indicated by high concentrations of DOC in ground water on the terrace and floodplain. Additional sampling and analyses will be required to evaluate the possibility of organic contamination. 


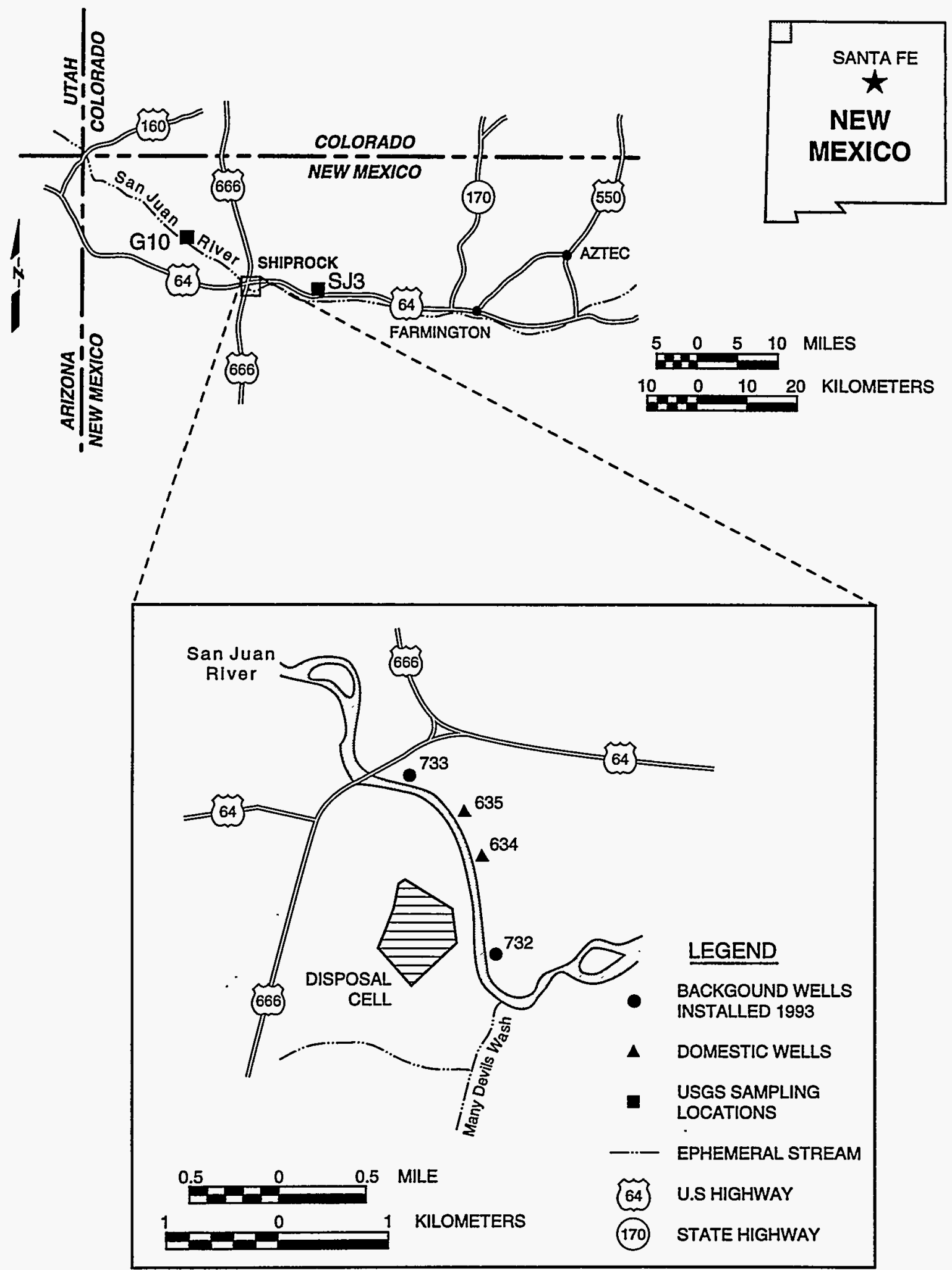

FIGURE 3.11

BACKGROUND WELLS USED FOR QUALITATIVE (SJ3, G10) AND QUANTITATIVE $(732,733,634,635)$ ANALYSIS OF GROUND WATER IN THE FLOODPLAIN AQUIFER SHIPROCK, NEW MEXICO, SITE 


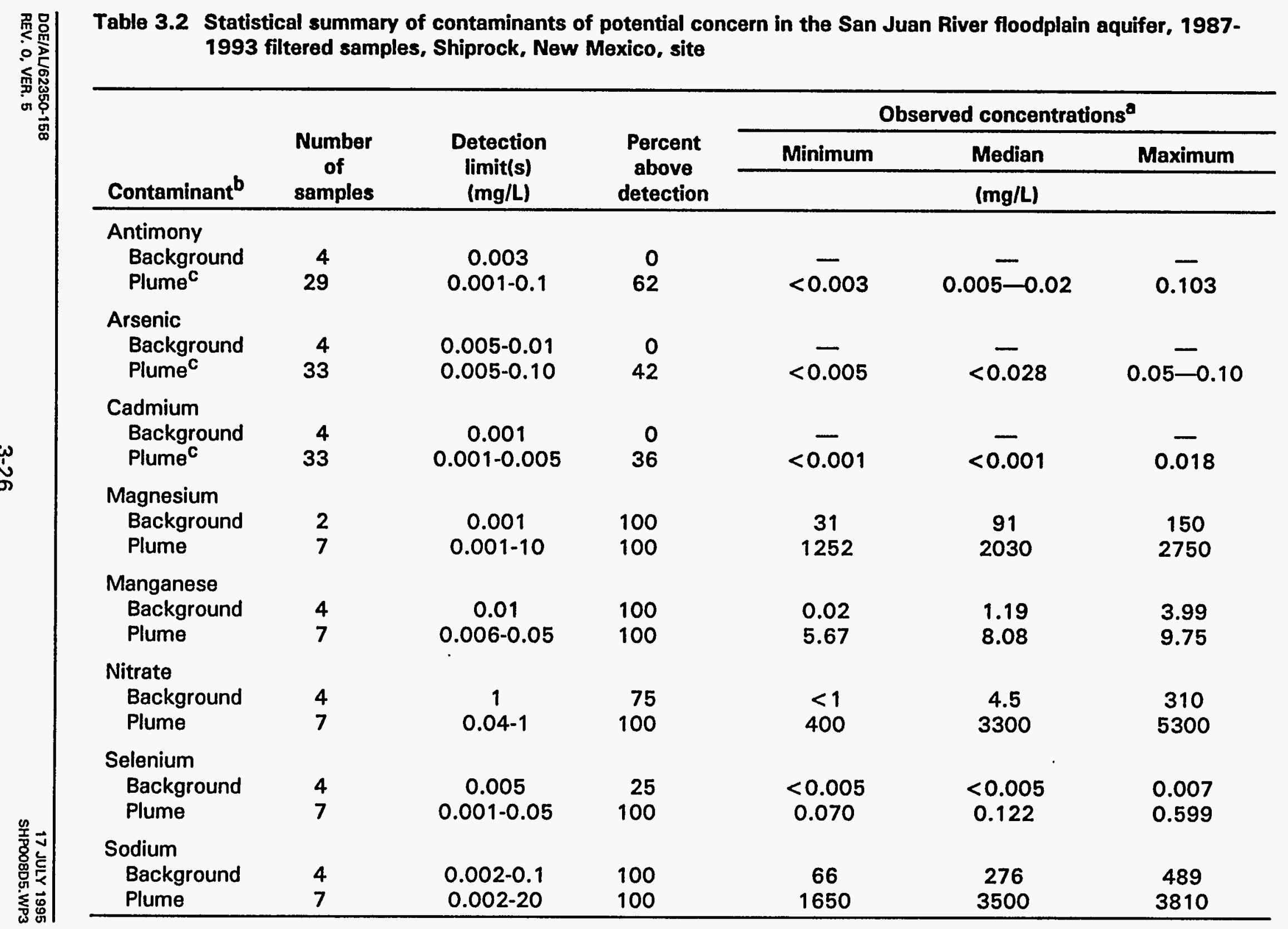


Table 3.2 Statistical summary of contaminants of potential concern in the San Juan River floodplain aquifer, 1987-1993 filtered samples, Shiprock, New Mexico, site (Concluded)

\begin{tabular}{|c|c|c|c|c|c|c|}
\hline \multirow[b]{3}{*}{ Contaminant $^{\mathbf{b}}$} & \multirow{3}{*}{$\begin{array}{c}\text { Number } \\
\text { of } \\
\text { samples }\end{array}$} & \multirow{3}{*}{$\begin{array}{c}\text { Detection } \\
\operatorname{limit}(\mathrm{s}) \\
(\mathrm{mg} / \mathrm{L})\end{array}$} & \multirow{3}{*}{$\begin{array}{c}\text { Percent } \\
\text { above } \\
\text { detection }\end{array}$} & \multicolumn{3}{|c|}{ Observed concentrations $^{\circledR}$} \\
\hline & & & & Minimum & Median & Maximum \\
\hline & & & & & (mg/L) & \\
\hline $\begin{array}{l}\text { Strontium } \\
\text { Background } \\
\text { Plume }\end{array}$ & $\begin{array}{l}4 \\
7\end{array}$ & $\begin{array}{l}0.01-0.10 \\
0.01-0.10\end{array}$ & $\begin{array}{l}100 \\
100\end{array}$ & $\begin{array}{l}1.60 \\
8.94\end{array}$ & $\begin{array}{c}3.28 \\
10.10\end{array}$ & $\begin{array}{c}4.61 \\
14.00\end{array}$ \\
\hline $\begin{array}{l}\text { Sulfate } \\
\text { Background } \\
\text { Plume }\end{array}$ & $\begin{array}{l}4 \\
7\end{array}$ & $\begin{array}{c}0.1-1 \\
0.1-10\end{array}$ & $\begin{array}{l}100 \\
100\end{array}$ & $\begin{array}{c}256 \\
6230\end{array}$ & $\begin{array}{c}1465 \\
13000\end{array}$ & $\begin{array}{c}2860 \\
15600\end{array}$ \\
\hline $\begin{array}{l}\text { Uranium } \\
\text { Background } \\
\text { Plume }\end{array}$ & $\begin{array}{l}4 \\
7\end{array}$ & $\begin{array}{l}0.001-0.003 \\
0.001-0.003\end{array}$ & $\begin{array}{l}100 \\
100\end{array}$ & $\begin{array}{c}0.010 \\
1.64\end{array}$ & $\begin{array}{c}0.016 \\
2.80\end{array}$ & $\begin{array}{c}0.023 \\
4.07\end{array}$ \\
\hline
\end{tabular}

aDue to nondetectable measurements, these statistics may not be available. If a range is reported, the statistic is known to lie somewhere within that range.

bPlume data are from well 615 except as noted. Background data are from wells 634, 635, 732, and 733.

${ }^{c}$ Because of low detectability, data from the following plume wells were combined: $608,609,610,611,613,614$, and 615 . 


\section{Terrace system}

The hydrogeologic conceptual model for the terrace supports the observation that water quality data from existing wells on the terrace are indicative of water from the milling activities. A statistical summary of contaminant of potential concern water quality data for the terrace alluvium is presented in Table 3.3. Ground water monitor well locations are shown in Figure 3.9. Ground water from monitor wells 600 and 602, analyzed between 1988 and 1993, show high concentrations of uranium, nitrate, and sulfate. Ground water samples from monitor wells $725,726,727,728$, and 731 , constructed in the spring of 1993, were also high in nitrate, uranium, and sulfate. These monitor wells better define the extent of contamination to the east, south, and west of the disposal cell. However, the lateral extent of contamination has not been fully defined by the existing monitoring system.

Ground water flowing from the terrace aquifer to the floodplain aquifer contaminates ground water in the alluvial floodplain system, but the extent is unknown. This is apparent because water quality data from seep locations 425 and 426 (Figure 3.10), originating in the terrace alluvium, show elevated nitrate, uranium, and sulfate (uranium milling indicator constituents).

\section{Floodplain system}

The floodplain alluvium is characterized by elevated TDS and other constituents associated with uranium milling (e.g., sulfate, nitrate, and uranium). The horizontal distributions of sulfate, nitrate, and uranium are delineated in Figures $3.12,3.13$, and 3.14 , respectively. To characterize water quality in the floodplain and to determine constituents that are elevated above background levels, water quality data from wells showing the highest levels of contamination (monitor wells 608 through 613 and 615) between 1987 and 1993 were evaluated. Concentrations of contaminants of potential concern in the floodplain plume are summarized in Table 3.2. Ground water sampled from the floodplain wells has TDS values ranging from 700 to $64,200 \mathrm{mg} / \mathrm{L}$ and a $\mathrm{pH}$ ranging from 6.5 to 8.0. Due to the measurement of high TDS concentrations ' $(64,000 \mathrm{mg} / \mathrm{L})$, plume density may be affecting movement of the plume or may explain widely differing TDS concentrations in the floodplain alluvial area. Uranium has been measured as high as $4.07 \mathrm{mg} / \mathrm{L}$ in monitor well 615 . The wide variability of contaminant distribution is attributed to differing flow paths of contaminated water from the terrace into the floodplain. These flow paths included surface transport of leachate and raffinate spills from the terrace onto the floodplain and flow paths from ponds constructed on the floodplain during milling operations. Contaminated ground water from the terrace is also thought to be transported through the various flow paths into the floodplain as identified in the conceptual model (see Section 3.3.1, Hydrogeologic Setting).

Monitor wells 608, 610,614, and 615 (Figures 3.12, 3.13, and 3.14) are in the high contaminant of potential concern concentration portions of the plume along the base of the escarpment. Filtered water quality data collected between 1987 


\begin{tabular}{|c|c|c|c|c|c|c|c|}
\hline \multirow{4}{*}{ 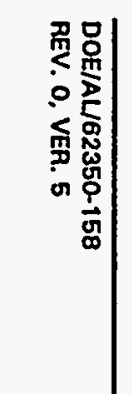 } & \multicolumn{7}{|c|}{$\begin{array}{l}\text { Summary of contaminants of potential concern }{ }^{\mathrm{a}} \text { in ground water in the terrace aquifer, Shiprock, New } \\
\text { Mexico, site, 1988-1993 }\end{array}$} \\
\hline & \multirow[b]{3}{*}{ Contaminant } & \multirow{3}{*}{$\begin{array}{c}\begin{array}{c}\text { Number } \\
\text { of } \\
\text { samples }\end{array} \\
\end{array}$} & \multirow{3}{*}{$\begin{array}{c}\text { Detection } \\
\text { limits } \\
\text { (mg/L) } \\
\end{array}$} & \multirow{3}{*}{$\begin{array}{c}\text { Percent } \\
\text { above } \\
\text { detection }\end{array}$} & \multicolumn{3}{|c|}{ Observed concentrations $^{b}$} \\
\hline & & & & & Minimum & Median & Maximum \\
\hline & & & & & & (mg/L) & \\
\hline & Antimony & & & & & & \\
\hline & $600 / 602$ & 12 & $0.001-0.02$ & 58 & $<0.007$ & $0.018-0.024$ & 0.106 \\
\hline & Arsenic & & & & & & \\
\hline & $600 / 602$ & 14 & $0.005-0.1$ & 36 & $<0.005$ & $<0.04$ & 0.31 \\
\hline & $725-731$ & 5 & 0.005 & 0 & - & - & - \\
\hline \multirow{12}{*}{$\begin{array}{l}\omega \\
\dot{\omega}\end{array}$} & Cadmium ${ }^{d}$ & & & & & & \\
\hline & $600 / 602$ filtered & 14 & $0.0001-$ & 50 & $\leq 0.0007$ & $<0.002$ & 0.013 \\
\hline & $600 / 602$ unfiltered & 2 & 0.005 & 50 & $<0.001$ & $<0.003$ & 0.005 \\
\hline & 725-731 filtered & 5 & 0.001 & 20 & $<0.001$ & $<0.001$ & 0.001 \\
\hline & 725-731 unfiltered & 5 & $\begin{array}{l}0.001 \\
0.001\end{array}$ & 100 & 0.001 & 0.002 & 0.006 \\
\hline & Magnesium & & & & & & \\
\hline & $600 / 602$ & 14 & $0.001-10$ & 100 & 543 & 1339 & 2940 \\
\hline & $725-731$ & 0 & - & - & - & - & - \\
\hline & Manganese & & & & & & \\
\hline & $600 / 602$ & 12 & $0.006-0.05$ & 100 & 0.6 & 1.3 & 2.4 \\
\hline & $725-731$ & 5 & 0.01 & 80 & $<0.01$ & 0.4 & 1.5 \\
\hline & Nitrate & & & & & & \\
\hline \multirow{2}{*}{$\frac{9}{3} \vec{y}$} & $600 / 602$ & 14 & $0.044-1.0$ & 100 & 36 & 236 & 945 \\
\hline & $725-731$ & 5 & 1.0 & 100 & 26 & 738 & 2310 \\
\hline
\end{tabular}


Table 3.3 Summary of contaminants of potential concern ${ }^{\circ}$ in ground water in the terrace aquifer, Shiprock, New Mexico, site, 1988-1993 (Concluded)

\begin{tabular}{|c|c|c|c|c|c|c|}
\hline \multirow[b]{3}{*}{ Contaminant } & \multirow{3}{*}{$\begin{array}{c}\text { Number } \\
\text { of } \\
\text { samples }\end{array}$} & \multirow{3}{*}{$\begin{array}{c}\text { Detection } \\
\text { limits } \\
\text { (mg/L) }\end{array}$} & \multirow{3}{*}{$\begin{array}{l}\text { Percent } \\
\text { above } \\
\text { detection }\end{array}$} & \multicolumn{3}{|c|}{ Observed concentrations $^{b}$} \\
\hline & & & & Minimum & Median & Maximum \\
\hline & & & & & (mg/L) & \\
\hline $\begin{array}{l}\text { Selenium } \\
600 / 602 \\
725-731\end{array}$ & $\begin{array}{r}14 \\
5\end{array}$ & $\begin{array}{c}0.001-0.05 \\
0.005\end{array}$ & $\begin{array}{l}57 \\
60\end{array}$ & $\begin{array}{l}<0.005 \\
<0.01\end{array}$ & $\begin{array}{c}0.04-0.06 \\
0.072\end{array}$ & $\begin{array}{l}0.80 \\
0.25\end{array}$ \\
\hline $\begin{array}{l}\text { Sodium } \\
600 / 602 \\
725-731\end{array}$ & $\begin{array}{r}14 \\
5\end{array}$ & $\begin{array}{c}0.002-20 \\
0.1\end{array}$ & $\begin{array}{l}100 \\
100\end{array}$ & $\begin{array}{c}2120 \\
534\end{array}$ & $\begin{array}{l}3215 \\
1130\end{array}$ & $\begin{array}{l}4090 \\
3030\end{array}$ \\
\hline $\begin{array}{r}\text { Strontium } \\
600 / 602 \\
725-731\end{array}$ & $\begin{array}{r}14 \\
5\end{array}$ & $\begin{array}{c}0.01-0.1 \\
0.01\end{array}$ & $\begin{array}{l}100 \\
100\end{array}$ & $\begin{array}{l}6.2 \\
4.9\end{array}$ & $\begin{array}{l}9.2 \\
7.4\end{array}$ & $\begin{array}{l}15.6 \\
14.7\end{array}$ \\
\hline $\begin{array}{l}\text { Sulfate } \\
600 / 602 \\
725-731\end{array}$ & $\begin{array}{r}16 \\
5\end{array}$ & $\begin{array}{c}0.1-10 \\
1.0\end{array}$ & $\begin{array}{l}100 \\
100\end{array}$ & $\begin{array}{l}9200 \\
3870\end{array}$ & $\begin{array}{c}13,900 \\
4,780\end{array}$ & $\begin{array}{l}18,100 \\
18,100\end{array}$ \\
\hline $\begin{array}{l}\text { Uranium } \\
600 / 602 \\
\quad 725-731\end{array}$ & $\begin{array}{r}14 \\
5\end{array}$ & $\begin{array}{c}0.001-0.01 \\
0.001\end{array}$ & $\begin{array}{l}100 \\
100\end{array}$ & $\begin{array}{c}0.81 \\
0.022\end{array}$ & $\begin{array}{l}1.18 \\
0.48\end{array}$ & $\begin{array}{l}1.57 \\
0.50\end{array}$ \\
\hline
\end{tabular}

Data are from filtered samples unless otherwise noted.

${ }^{b}$ Due to nondetected measurements, these statistics may not be observable. If a range is given, the statistic is known to lie somewhere within the range.

c725-731 refers to wells 725, 726, 727, 728, and 731. These wells were sampled only once, in 1993.

dConcentrations from both filtered and unfiltered samples are presented for those constituents where filtering may be expected to remove a significant amount of the constituent from the water. However, when concentrations are low, natural variation and measurement error may be greater than the effects of filtering. 

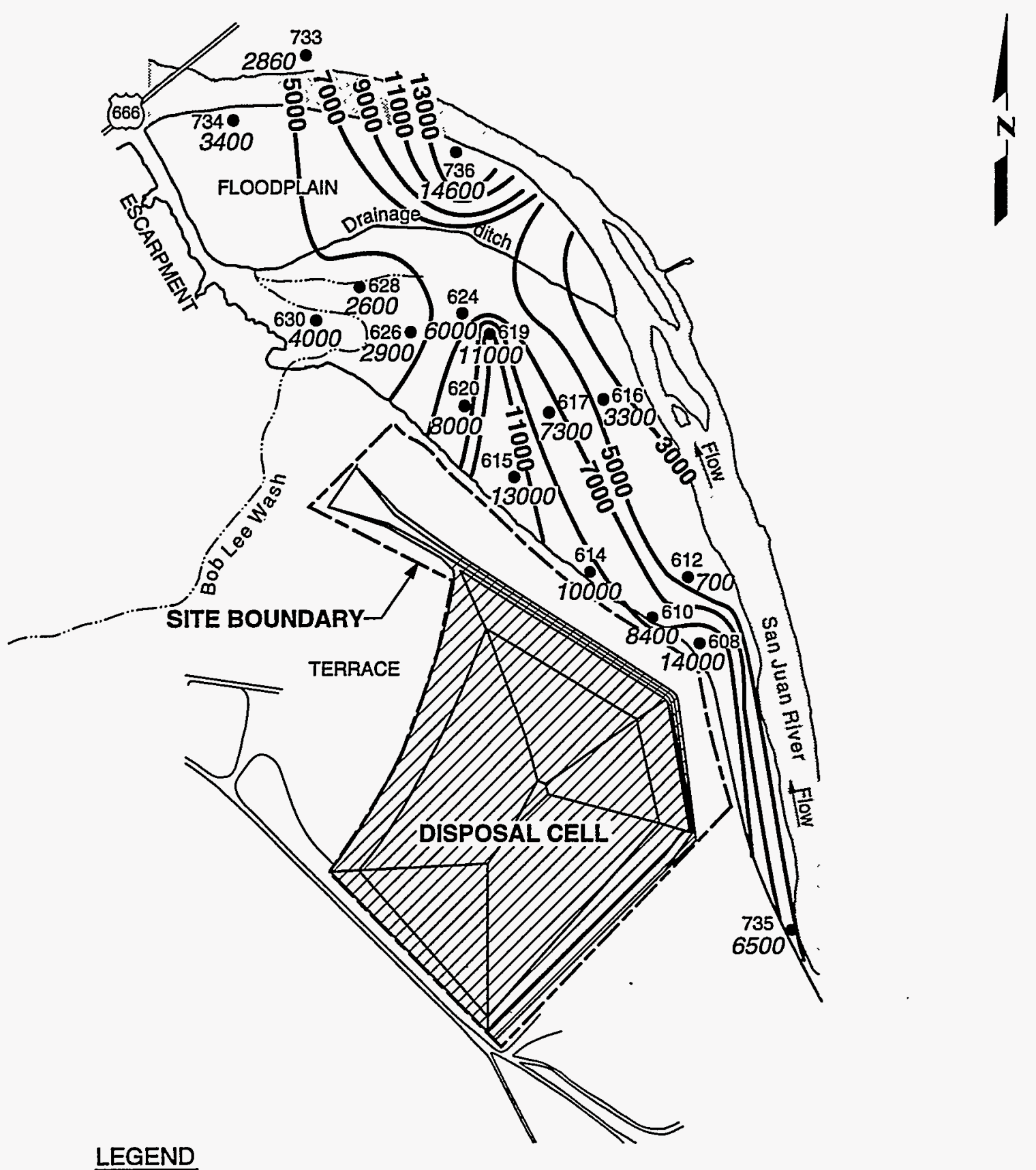

LEGEND

- 734 GROUND WATER MONITOR WELL

3400 SULFATE CONCENTRATION (mg/L)

5000 - SULFATE ISOPLETH

-..- EPHEMERAL STREAM

666 U.S. HIGHWAY

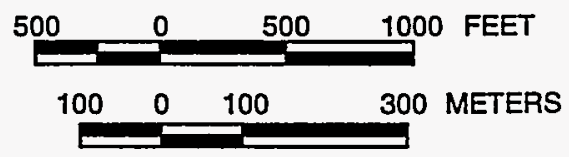

NOTE: WATER QUALITY DATA FROM SEPTEMBER 1992 EXCEPT MONITOR WELLS 734, 735, 736 (APRIL 1993); 612 (APRIL 1989).

FIGURE 3.12

SULFATE CONCENTRATIONS IN FLOODPLAIN ALLUVIUM SHIPROCK, NEW MEXICO, SITE 

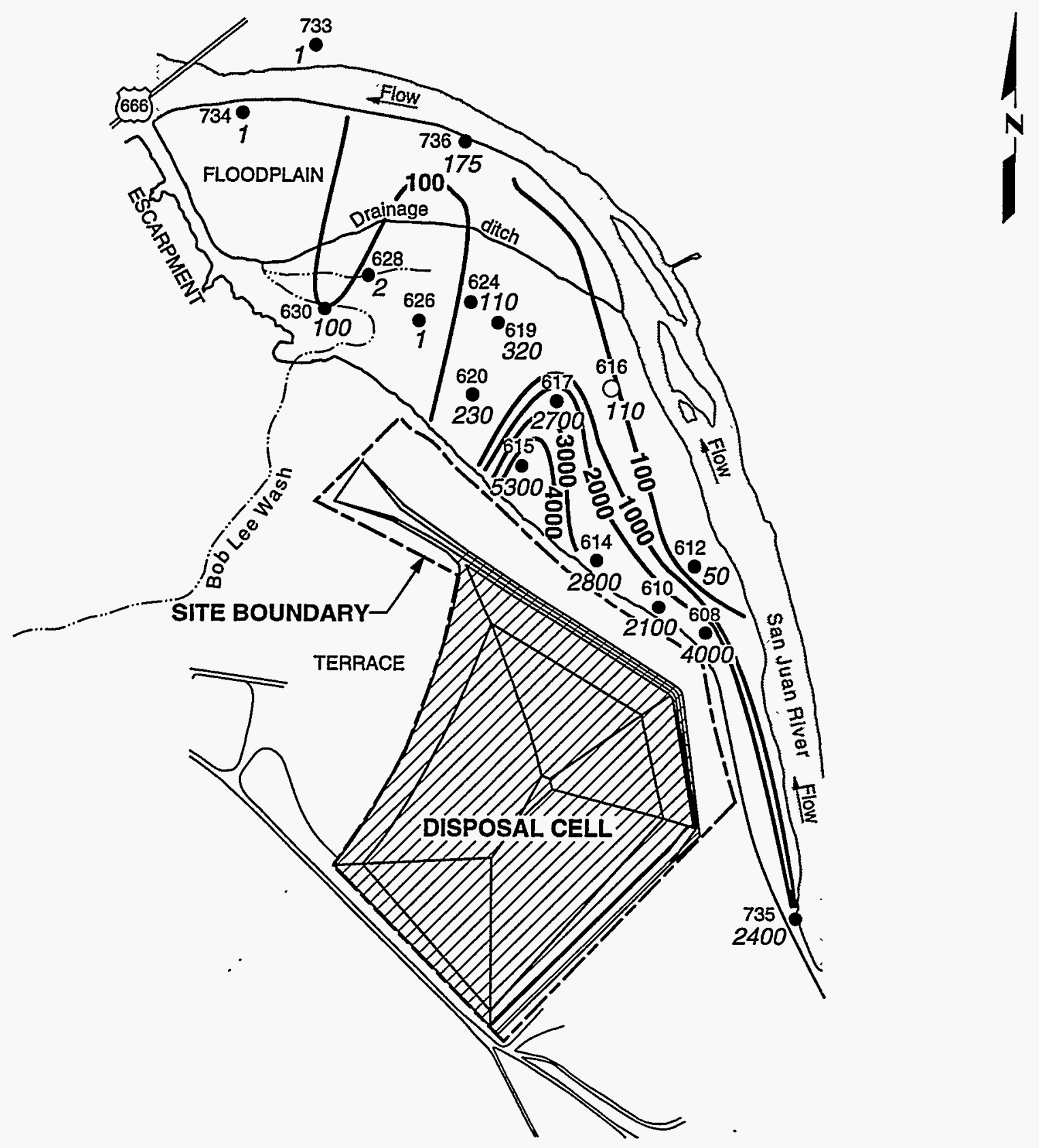

\section{LEGEND}

$\begin{array}{ll}620 & \text { GROUND WATER MONITOR WELL } \\ 230 & \text { NITRATE CONCENTRATION (mg/L) }\end{array}$

1000 - NITRATE ISOPLETH

-..-.. EPHEMERAL STREAM

666 U.S. HIGHWAY

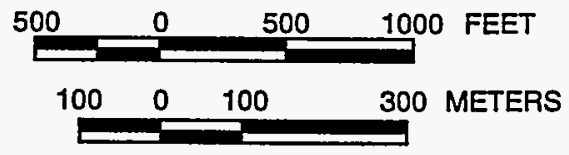

NOTE: WATER QUALITY DATA FROM SEPTEMBER 1992 EXCEPT MONITOR WELLS 734, 735, 736 (APRIL 1993), 612 (APRIL 1989), 603 (JUNE 1990).

FIGURE 3.13

\section{NITRATE CONCENTRATIONS IN FLOODPLAIN ALLUVIUM SHIPROCK, NEW MEXICO, SITE}



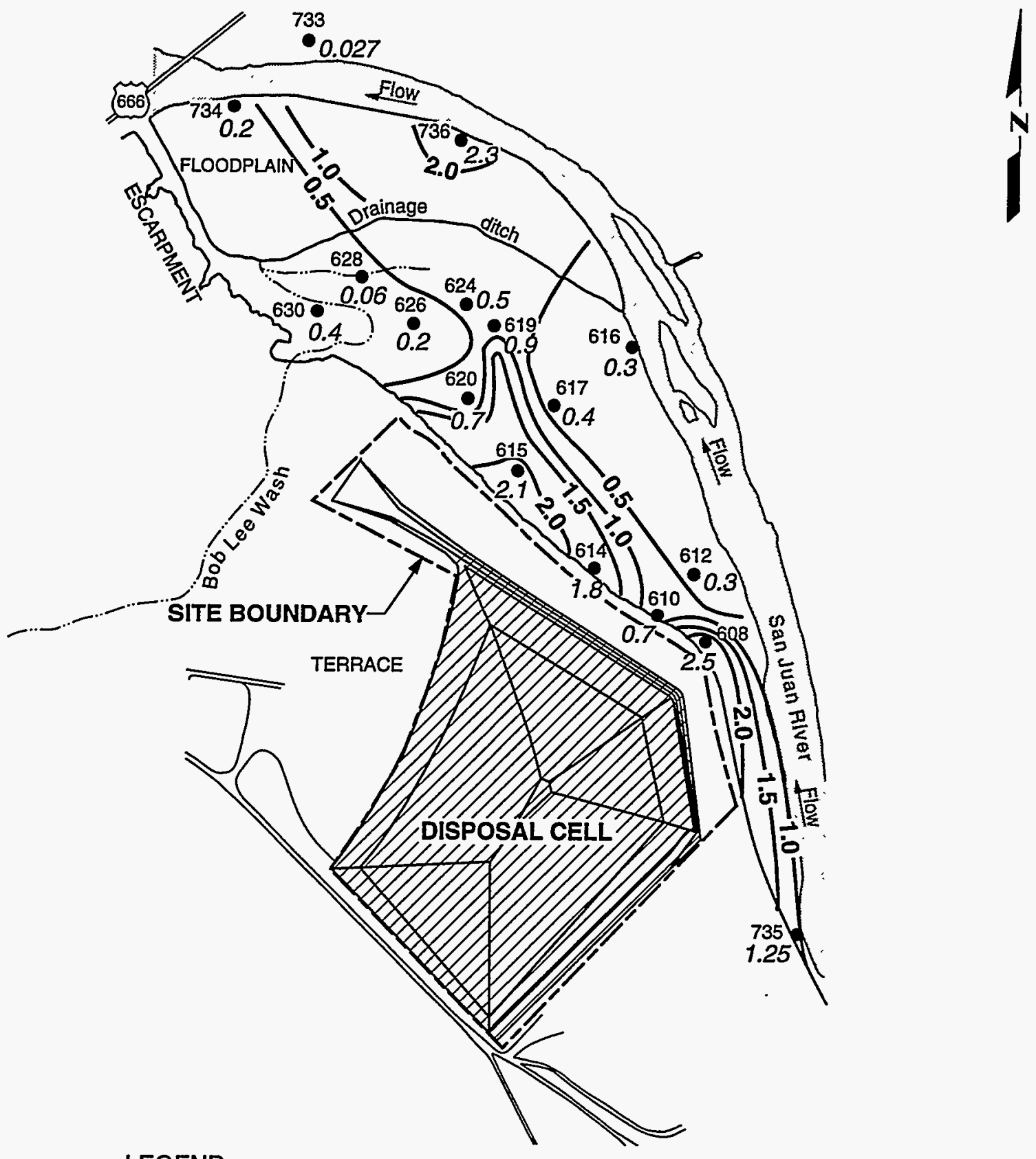

LEGEND

734 GROUND WATER MONITOR WELL

0.2 URANIUM CONCENTRATION (mg/)

2.0 - URANIUM ISOPLETH

- - EPHEMERAL STREAM

666 U.S. HIGHWAY

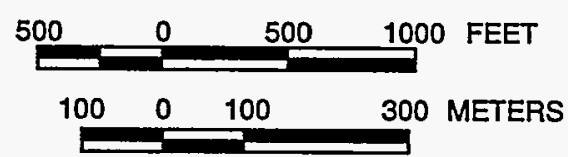

NOTE: WATER QUALITY DATA FROM SEPTEMBER 1992 EXCEPT MONITOR WELLS 734, 735, 736

FIGURE 3.14 (APRIL 1993), 612 (APRIL 1989).

\section{URANIUM CONCENTRATIONS IN FLOODPLAIN ALLUVIUM SHIPROCK, NEW MEXICO, SITE}


and 1993 indicate that monitor wells 608 and 615 have the highest concentrations of milling-related contaminants. Conversely, monitor well 612 appears to be somewhat diluted and is influenced by flow from the San Juan River, especially during periods of high water flow. The remaining wells in the floodplain are located downgradient from the wells located in the plume; ground water in most of these wells is not as contaminated. Generally, ground water contamination in the floodplain shows a complex, heterogeneous distribution probably reflecting the initial distribution of contaminants.

Time series analysis of chemical constituents shows slight trends, either increasing or decreasing, of solute concentrations in ground water. In the most highly impacted area of the floodplain (the eastern portion), species such as nitrate and chloride appear to be increasing, sulfate and TDS are constant, and uranium shows a slight decrease. Observable concentrations of selenium and arsenic in ground water are sporadic and may in part be caused by analytical inconsistencies. An uneven distribution of contaminants of potential concern indicates that various plumes are present throughout the alluvial system. Furthermore, the distribution of contamination may be affected by preferential flow paths in the aquifer and by the location of ponds and episodic discharges onto different portions of the floodplain during the milling operations.

\section{Surface Water}

Sampling locations for San Juan River surface water quality are shown in Figure 3.9. Analyses of one round of unfiltered water samples from seven San Juan River sampling locations (546, 552, 554, 548, 549, 550, and 551), collected in February 1993, are summarized in Table 3.4. Downstream concentrations of arsenic, nitrate, sodium, and sulfate are statistically above background levels determined at the upstream locations. The remaining sampled contaminants of potential concern are at or below background values.

The impact of milling activities on the water quality of the San Juan River is difficult to determine because of the variable water chemistry and river flow (Goetz and Abeyta, 1987). However, mixing calculations presented in the Shiprock baseline risk assessment (DOE, 1994a) using water quality data and water flux from the San Juan River (at low flow) and contaminated ground water at the downstream edge of the floodplain (monitor well 736) show that concentrations of the contaminants of potential concern are within the range of ambient San Juan River water quality (i.e., uranium at $0.006 \mathrm{mg} / \mathrm{L}$, nitrate at $0.5 \mathrm{mg} / \mathrm{L}$, and sulfate at $222 \mathrm{mg} / \mathrm{L}$ ). The results suggest that the impact of contaminated ground water from the floodplain on San Juan River water quality is negligible.

\subsubsection{Contaminant fate and transport}

The fate and mobility of contaminants in ground water beneath and downgradient from the former processing site are discussed in this section. Aside from hydrodynamic dispersion, geochemical sinks in the aquifer are 
Table 3.4 Statistical summary of the San Juan River water quality at the Shiprock, New Mexico, site, February 25, 1993

\begin{tabular}{|c|c|c|c|c|c|}
\hline \multirow[b]{3}{*}{ Constituent } & \multirow{3}{*}{$\begin{array}{c}\text { Number of } \\
\text { samples }\end{array}$} & \multirow{3}{*}{$\begin{array}{c}\text { Detection } \\
\text { limit }\end{array}$} & \multicolumn{3}{|c|}{ Observed concentrations } \\
\hline & & & Minimum & Median & Maximum \\
\hline & & & & $(\mathrm{mg} / \mathrm{L})^{\mathrm{a}}$ & \\
\hline $\begin{array}{l}\text { Arsenic }^{b} \\
\text { Upstream }^{c} \\
\text { Downstream }^{d}\end{array}$ & $\begin{array}{l}3 \\
4\end{array}$ & $\begin{array}{l}0.005 \\
0.005\end{array}$ & $\begin{array}{l}0.007 \\
0.008\end{array}$ & $\begin{array}{l}0.007 \\
0.010\end{array}$ & $\begin{array}{l}0.008 \\
0.012\end{array}$ \\
\hline $\begin{array}{l}\text { Cadmium }^{e} \\
\text { Upstream } \\
\text { Downstream }\end{array}$ & $\begin{array}{l}3 \\
4\end{array}$ & $\begin{array}{l}0.001 \\
0.001\end{array}$ & - & - & - \\
\hline $\begin{array}{l}\text { Calcium } \\
\text { Upstream } \\
\text { Downstream }\end{array}$ & $\begin{array}{l}3 \\
4\end{array}$ & $\begin{array}{l}0.5 \\
0.5\end{array}$ & $\begin{array}{l}73 \\
69\end{array}$ & $\begin{array}{l}73 \\
90\end{array}$ & $\begin{array}{l}77 \\
95\end{array}$ \\
\hline $\begin{array}{l}\text { Chromium } \\
\text { Upstream } \\
\text { Downstream }\end{array}$ & $\begin{array}{l}3 \\
4\end{array}$ & $\begin{array}{l}0.01 \\
0.01\end{array}$ & $\begin{array}{l}0.03 \\
0.03\end{array}$ & $\begin{array}{l}0.03 \\
0.05\end{array}$ & $\begin{array}{l}0.03 \\
0.07\end{array}$ \\
\hline $\begin{array}{l}\text { Iron } \\
\text { Upstream } \\
\text { Downstream }\end{array}$ & $\begin{array}{l}3 \\
4\end{array}$ & $\begin{array}{l}0.03 \\
0.03\end{array}$ & $\begin{array}{l}42 \\
40\end{array}$ & $\begin{array}{l}44 \\
54\end{array}$ & $\begin{array}{l}47 \\
69\end{array}$ \\
\hline $\begin{array}{l}\text { Lead } \\
\text { Upstream } \\
\text { Downstream }\end{array}$ & $\begin{array}{l}3 \\
4\end{array}$ & $\begin{array}{l}0.003 \\
0.003\end{array}$ & $\begin{array}{l}0.024 \\
0.024\end{array}$ & $\begin{array}{l}0.025 \\
0.030\end{array}$ & $\begin{array}{l}0.026 \\
0.032\end{array}$ \\
\hline $\begin{array}{l}\text { Manganese } \\
\text { Upstream } \\
\text { Downstream }\end{array}$ & $\begin{array}{l}3 \\
4\end{array}$ & $\begin{array}{l}0.01 \\
0.01\end{array}$ & $\begin{array}{l}1.03 \\
0.88\end{array}$ & $\begin{array}{l}1.12 \\
1.10\end{array}$ & $\begin{array}{l}1.23 \\
1.17\end{array}$ \\
\hline $\begin{array}{l}\text { Molybdenum } \\
\text { Upstream } \\
\text { Downstream }\end{array}$ & $\begin{array}{l}3 \\
4\end{array}$ & $\begin{array}{l}0.01 \\
0.01\end{array}$ & - & - & - \\
\hline $\begin{array}{l}\text { Nitrate }^{b} \\
\text { Upstream } \\
\text { Downstream }\end{array}$ & $\begin{array}{l}3 \\
4\end{array}$ & $\begin{array}{l}1.0 \\
1.0\end{array}$ & $\begin{array}{r}<1.0 \\
1.1\end{array}$ & $\begin{array}{r}<1.0 \\
1.5\end{array}$ & $\begin{array}{r}<1.0 \\
1.7\end{array}$ \\
\hline $\begin{array}{l}\text { Selenium } \\
\text { Upstream } \\
\text { Downstream }\end{array}$ & $\begin{array}{l}3 \\
4\end{array}$ & $\begin{array}{l}0.05 \\
0.05\end{array}$ & - & - & - \\
\hline $\begin{array}{l}\text { Sodium }^{b} \\
\text { Upstream } \\
\text { Downstream }\end{array}$ & $\begin{array}{l}3 \\
4\end{array}$ & $\begin{array}{l}1.0 \\
1.0\end{array}$ & $\begin{array}{l}35 \\
36\end{array}$ & $\begin{array}{l}35 \\
56\end{array}$ & $\begin{array}{l}36 \\
58\end{array}$ \\
\hline
\end{tabular}


Table 3.4 Statistical summary of the San Juan River water quality at the Shiprock, New Mexico, site, February 25, 1993 (Concluded)

\begin{tabular}{|c|c|c|c|c|c|}
\hline \multirow[b]{3}{*}{ Constituent } & \multirow{3}{*}{$\begin{array}{c}\text { Number of } \\
\text { samples }\end{array}$} & \multirow{3}{*}{$\begin{array}{c}\text { Detection } \\
\text { limit }\end{array}$} & \multicolumn{3}{|c|}{ Observed concentrations } \\
\hline & & & Minimum & Median & Maximum \\
\hline & & & \multicolumn{3}{|c|}{$(\mathrm{mg} / \mathrm{L})^{\mathrm{a}}$} \\
\hline $\begin{array}{l}\text { Sulfate } \\
\text { Upstream } \\
\text { Downstream }\end{array}$ & $\begin{array}{l}3 \\
4\end{array}$ & $\begin{array}{l}1.0 \\
1.0\end{array}$ & $\begin{array}{l}116 \\
121\end{array}$ & $\begin{array}{l}118 \\
190\end{array}$ & $\begin{array}{l}121 \\
205\end{array}$ \\
\hline $\begin{array}{l}\text { Strontium } \\
\text { Upstream } \\
\text { Downstream }\end{array}$ & $\begin{array}{l}3 \\
4\end{array}$ & $\begin{array}{l}0.01 \\
0.01\end{array}$ & $\begin{array}{l}0.82 \\
0.80\end{array}$ & $\begin{array}{l}0.83 \\
1.12\end{array}$ & $\begin{array}{l}0.85 \\
1.18\end{array}$ \\
\hline $\begin{array}{l}\text { Uranium } \\
\text { Upstream } \\
\text { Downstream }\end{array}$ & $\begin{array}{l}3 \\
4\end{array}$ & $\begin{array}{l}0.001 \\
0.001\end{array}$ & $\begin{array}{r}<0.001 \\
0.001\end{array}$ & $\begin{array}{l}0.001 \\
0.001\end{array}$ & $\begin{array}{l}0.002 \\
0.001\end{array}$ \\
\hline $\begin{array}{l}\text { Vanadium } \\
\text { Upstream } \\
\text { Downstream }\end{array}$ & $\begin{array}{l}3 \\
4\end{array}$ & $\begin{array}{l}0.01 \\
0.01\end{array}$ & $\begin{array}{l}0.09 \\
0.08\end{array}$ & $\begin{array}{l}0.09 \\
0.11\end{array}$ & $\begin{array}{l}0.09 \\
0.14\end{array}$ \\
\hline Radionuclides & & & & pCi/L & \\
\hline $\begin{array}{l}\text { Lead-210 } \\
\text { Upstream } \\
\text { Downstream }\end{array}$ & $\begin{array}{l}3 \\
4\end{array}$ & & $\begin{array}{l}2.1 \\
1.0\end{array}$ & $\begin{array}{l}2.6 \\
1.8\end{array}$ & $\begin{array}{l}3.3 \\
2.6\end{array}$ \\
\hline $\begin{array}{l}\text { Polonium-210 } \\
\text { Upstream } \\
\text { Downstream }\end{array}$ & $\begin{array}{l}3 \\
4\end{array}$ & & $\begin{array}{l}0.0 \\
0.0\end{array}$ & $\begin{array}{l}0.0 \\
0.3\end{array}$ & $\begin{array}{l}0.3 \\
1.1\end{array}$ \\
\hline $\begin{array}{l}\text { Radium-226 } \\
\text { Upstream } \\
\text { Downstream }\end{array}$ & $\begin{array}{l}3 \\
4\end{array}$ & & $\begin{array}{l}1.3 \\
1.5\end{array}$ & $\begin{array}{l}2.5 \\
1.8\end{array}$ & $\begin{array}{l}2.9 \\
1.9\end{array}$ \\
\hline $\begin{array}{l}\text { Thorium-230 } \\
\text { Upstream } \\
\text { Downstream }\end{array}$ & $\begin{array}{l}3 \\
4\end{array}$ & & $\begin{array}{l}0.1 \\
0.1\end{array}$ & $\begin{array}{l}0.2 \\
0.2\end{array}$ & $\begin{array}{l}0.3 \\
0.6\end{array}$ \\
\hline
\end{tabular}

Unfiltered water samples.

bstatistically elevated above background at the 0.05 level of significance.

CUpstream locations: 546, 552, 554 (each location sampled one time).

dDownstream locations: 548, 549, 550, 551 (each location sampled one time).

${ }^{\circ}$ Analyzed for, but not detected.

Note: Data presented in table correspond to a flow rate of about 2,740 cubic feet 177.5 $\mathrm{m}^{3}$ ) per second in the San Juan River at Shiprock. 
responsible for the reduction of contaminant concentrations in ground water. Chemical reactions (oxidation/reduction, sorption onto the aquifer matrix, precipitation, coprecipitation with other mineral phases), microbial reactions, transport due to the advective flow of ground water, and radioactive decay will reduce the concentration of contaminants along the flowpath. Sorption onto the aquifer matrix and precipitation are the primary processes that reduce contaminant concentrations.

The type and concentrations of species and complexes in natural waters depend on the concentration, availability of various anions and cations, and $\mathrm{pH}$ and $\mathrm{Eh}$ conditions. Species and saturation indices of the contaminants of concern have been calculated using the geochemical code MINTEOA2 (Allison et al., 1991) and 1993 water quality data from the most contaminated monitor wells on the alluvial floodplain (monitor wells 608 through 613 and 615). The fates of specific contaminants of potential concern in and down the contaminant flow paths are addressed in the following subsections and are applicable for both the terrace and floodplain aquifers.

\section{Antimony}

Low concentrations of antimony are present in ground water, probably in the $\mathrm{Sb}(\mathrm{III})$ and $\mathrm{Sb}(\mathrm{V})$ oxidation states and complexed as an oxyion or hydroxyl. Oxide and hydroxide solid phases are thermodynamically oversaturated in ground water where measurable quantities of antimony exist. Although not much is known about the kinetics of precipitation or sorption, antimony is not measurable in wells downgradient from monitor well 615. This suggests that either sorption onto aquifer materials, such as metal oxides or clays (Rai and Zachara, 1984), or precipitation is controlling the concentration of antimony in the ground water flow path.

\section{Arsenic}

Arsenic is present in ground water as an As(V) oxyanion. Arsenic is moderately mobile in an oxidizing aqueous environment as an arsenate species but generally, the mobility increases as the oxidation state of arsenic decreases (Rai and Zachara, 1984). Arsenite (As(III)) has a greater solubility with respect to solid mineral phases, and aqueous species generally sorb to the aquifer matrix less readily than $A s(V)$ species. Hydrodynamic dispersion and sorption onto aquifer materials (i.e., metal oxides and clay minerals [Rai and Zachara, 1984]) are responsible for low concentrations of arsenic in ground water downgradient from the contaminant plume.

\section{Cadmium}

Cadmium is present in the plume in low concentrations as a divalent cadmium ion and complexed with carbonate, sulfate, and nitrate. According to geochemical modeling, cadmium is undersaturated with respect to ground water, suggesting that hydrodynamic dispersion (dilution), sorption onto organic 
and inorganic aquifer materials (Rai and Zachara, 1984), and ion exchange are responsible for decreased concentrations in the flow path.

\section{Magnesium}

Magnesium is present in ground water as a magnesium ion and complexed with sulfate and carbonate. The mineral phase magnesite is saturated with respect to ground water in the region of the plume. Magnesium will also be diluted through hydrodynamic dispersion and cation exchange with other cations in clay minerals. These processes reduce the concentrations in ground water along the ground water flow path.

\section{Manganese}

The mobility of manganese is primarily controlled by the redox state of the aquifer. Manganese is present in ground water in the Mn(II) valence state predominant as $\mathrm{Mn}^{2}+$ and complexed with sulfate and bicarbonate. Removal of manganese through sorption onto organic and inorganic aquifer materials (Rai and Zachara, 1984) and coprecipitation with iron phases may be occurring down the ground water flow path. Concentrations of manganese decrease downgradient from the plume, indicating attenuation is taking place.

\section{Nitrate}

Nitrogen contamination is present predominantly as nitrate (N(V)) and ammonium (N(III-)) in contaminated ground water. The nitrate plume in the alluvial floodplain (Figure 3.13 ) is currently moving north towards the San Juan River. The predominant mechanism responsible for the attenuation of nitrate in ground water is most likely denitrifying reactions that occur under suboxic conditions ( $<1 \mathrm{mg} / \mathrm{L}$ dissolved oxygen [DO]), which exist in ground water on the terrace and alluvial floodplain. Furthermore, the absence of oxygen and elevated level of nitrate in ground water suggest that nitrate is controlling the redox condition of ground water in the plume. Nitrate concentrations in ground water decrease from approximately $5300 \mathrm{mg} / \mathrm{L}$ in monitor well 615 to $100 \mathrm{mg} / \mathrm{L}$ in monitor well 624 (northwest of the plume) and $110 \mathrm{mg} / \mathrm{L}$ in monitor well 616 (southeast of the plume) (1992 and 1993 water quality data). The decrease in concentration suggests that nitrate is probably biologically transformed into molecular nitrogen in the aquifer along the ground water flow path. This is probably the case because 1) very little nitrate sorbs onto the aquifer matrix due to the conservative nature of nitrate, and 2) no nitrate solid mineral phases are thermodynamically saturated with respect to ground water in the region of the plume.

\section{Selenium}

Selenium is associated with uranium ore and is mobilized along with uranium during the acid leach portion of the milling process. Selenium as selenite, (Se(IV)), is the predominant species in the plume. Selenium concentrations 
decrease downgradient from the center of the plume, indicating that selenium is attenuated from ground water down the flow path. No selenium mineral phases are saturated with respect to ground water. This suggests that selenium is primarily removed from ground water through sorption onto the aquifer matrix due to the presence of ferric oxyhydroxides (Rai and Zachara, 1984) and diluted due to hydrodynamic dispersion.

\section{Sodium}

The addition of sodium chlorate as an oxidizing agent, dissolution of sodium minerals during the acid leach circuit, and cation exchange with calcium and magnesium in clays are responsible for the elevated concentration of sodium in contaminated ground water. Sodium is present in ground water predominantly as a cation, $\mathrm{Na}(\mathrm{l})$. The primary mechanism of sodium attenuation is most likely cation exchange with clay minerals, but sodium acts as a somewhat conservative cation if calcium or other divalent alkali earth elements are present in elevated concentrations within the system. Therefore, if divalent cations saturate clay exchange sites, sodium is expected to persist in ground water downgradient from the former mill site.

\section{Strontium}

Strontium is present in ground water primarily as the divalent strontium ion. Although no strontium mineral phases are saturated with respect to ground water, coprecipitation with gypsum and carbonate phases may remove some strontium from ground water. Along with hydrodynamic dispersion processes, cation exchange with clay minerals in the aquifer matrix will also reduce strontium concentrations.

\section{Sulfate}

Elevated concentrations of sulfate in ground water in the plume are due to the addition of $\mathrm{H}_{2} \mathrm{SO}_{4}$ during the milling process and the oxidation of sulfide minerals. Sulfate is present in ground water predominantly as a $\mathrm{SO}_{4}{ }^{2-}$ ion or is complexed with calcium, magnesium, or sodium. The mineral phase gypsum is saturated with respect to ground water in the alluvial and terrace systems and thus will most likely serve as a mechanism for the removal of sulfate from ground water. Ground water accessed by monitor wells directly downgradient from the most contaminated wells on the floodplain, monitor wells 615 and 608 (Figure 3.12), shows a decrease in sulfate concentrations. However, maximum concentrations of sulfate measured in ground water on the downstream edge of the floodplain at monitor well 736 approach $14,600 \mathrm{mg} / \mathrm{L}$, greater than what was measured in the center of the plume. This may be a hot spot of contamination and illustrates the heterogeneous distribution of contamination on the floodplain. As the plume migrates, hydrodynamic dispersion effects and precipitation of gypsum will be responsible for the decrease of sulfate concentrations along the ground water flow path. However, sulfate is expected to persist in the ground water for some time. 


\section{Uranium}

Uranium is present in ground water in the floodplain as a residual product of the milling process. Uranium is present in the plume predominantly as U(VI), uranyl tricarbonate, and dicarbonate complexes. These species are mobile under moderately oxidizing ground water at neutral $\mathrm{pH}$, conditions characteristic of the plume. Geochemical modeling indicates that no uranium mineral phases are saturated in the ground water. Therefore, sorption onto aquifer materials, i.e., iron oxyhydroxides (Kent et al., 1988; Hsi and Langmuir, 1985; Leckie et al., 1980) and organic materials (Nakashima, 1992), is most likely responsible for the removal of uranium from contaminated ground water down the flow path.

\subsubsection{Risk evaluation}

This risk evaluation reflects findings presented in the draft Baseline Risk Assessment of Ground Water Contamination at the Uranium Mill Tailings Site near Shiprock, New Mexico (DOE, 1994a).

\section{Terrace system}

The hydrogeologic conceptual model of the terrace system has characterized the aquifer as a limited resource due to low yield properties of the aquifer.

Therefore, no exposure pathways are expected for humans, livestock, or wildlife for the terrace system. The terrace aquifer cannot be fully evaluated until background ground water quality has been determined for this unit. However, background water quality might not be determined for the terrace system if the terrace ground water has originated from the former milling operations.

Nevertheless, the risk assessment has qualitatively evaluated the conditions in the terrace alluvium aquifer and has concluded that nitrate, sulfate, and uranium (Table 3.3) occur at concentration levels high enough to cause serious adverse health effects, even following short-term exposures should exposures occur. Because of the high concentrations of nitrate, sulfate, and uranium, the ground water is not suitable for use as drinking water or for livestock.

\section{Seeps along escarpment}

The seeps along the escarpment originate from contaminated ground water in the terrace aquifer. Because these seeps contribute contamination to water bodies identified on the floodplain, the seeps are addressed under the risk assessment to the floodplain system.

\section{Floodplain system}

At present, the San Juan River floodplain below the former uranium milling site is fenced, which restricts access to seeps and pools in the area. It is not expected that humans and livestock would be directly exposed to the seeps when alternate sources of good water are readily available in the immediate vicinity (such as Bob Lee Wash, artesian well water, or the San Juan River). 
Seep-contaminated surface water bodies existing on the floodplain could potentially form an incidental exposure pathway to humans, domestic animals, and wildlife. Levels of toxic constituents in seep water and sediments may result in adverse effects to aquatic and terrestrial organisms that reside in the area of the seeps should exposures occur.

The risk assessment has evaluated the contaminants of potential concern in the floodplain alluvium ground water. Several of these constituents (calcium, chloride, phosphate, potassium, and zinc) are essential nutrients, and the levels at which they are observed are within nutritional ranges even when added to expected dietary intake. Other contaminants (ammonium, boron, and nickel) exhibit low toxicity and are not expected to have toxic properties at measured concentrations. Arsenic, magnesium, manganese, nitrate, sodium, sulfate, and uranium remain as the contaminants of potential concern for the floodplain alluvium ground water.

The human exposure pathways that may occur on the floodplain include incidental ingestion of surface water and sediment, dermal contact with surface water, and consumption of contaminated meat or milk from livestock grazed and watered on the floodplain. Based on limited data, the risk assessment has determined that these exposures are not expected to immediately threaten human health. Additionally, adverse health effects would not be expected following ingestion of meat and milk from animals grazed and watered on the San Juan River floodplain. Additional data are required to completely evaluate the significance of these exposure pathways.

Potential exposure to livestock using the floodplain for forage and drinking water has also been evaluated. As a result of this evaluation, livestock could safely use the surface water bodies identified on the floodplain as their sole drinking water source, with the exception of the wet area below seep 425 . The health risks associated with incidental exposure of livestock or wildlife to the surface water in the pool below seep 425 are currently unknown. The nitrate levels observed in this water would be associated with methemoglobinemia in animals as a result of long-term exposure.

An analysis of surface water in the floodplain (excluding the seeps) and the San Juan River indicates that none of the constituents in these waters exceed Federal Water Quality Criteria for aquatic life. Based on this analysis, these bodies of water do not pose an ecological risk. However, additional sampling is required to verify this and determine if the constituents in the surface water have the potential to harm the terrestrial ecosystem. At the seeps, levels of nitrate and selenium could be toxic to aquatic organisms.

Terrestrial and aquatic organisms could be exposed to contaminants of potential concern in the floodplain alluvial aquifer via root uptake of contaminated water or construction of a pond using this water. Salt cedar and salt grass are the most common plant species in the San Juan River floodplain near the site. The UMTRA Ground Water Project currently is studying plant uptake of 
contaminants at other UMTRA sites. Depending on the results of these studies, decisions will be made regarding further investigations of plant uptake at the Shiprock site. Although biota samples have not been collected at the site, an analysis of the alluvial ground water quality indicated that none of the constituents were present at levels high enough to result in phytotoxicity. However, concentrations of selenium and boron were close enough to phytotoxic levels to warrant additional study of these two contaminants. At the seeps, water quality criteria and sediment quality criteria were insufficient to evaluate thoroughly the impacts of surface water and sediments to ecological receptors. Therefore, future site investigations are needed to assess the possible impact of contaminated media to aquatic and terrestrial flora and fauna as well as the potential for food chain transfer.

If a pond were filled with contaminated ground water from the floodplain aquifer, concentrations of antimony, chloride, manganese, nitrate, and selenium would exceed the Federal Water Quality Criteria, and such a pond would present a hazard to aquatic and possibly terrestrial organisms. In 1985, three waterfowl ponds were constructed in the floodplain. Concentrations of nitrate, sulfate, and uranium rose and in 1986 the ponds were filled in because they constituted a potential hazard to human health and the environment (Themelis, 1986).

In general, limitations for the Shiprock ecological risk assessment include the following:

- Only a small amount of ecological data was collected during this screening.

- Little is known about site-specific intake rates for wildlife or amounts of contaminants taken up by plants. General literature values were used in many cases.

- Only limited ecotoxicological reference data are available.

- Considerable uncertainty is associated with the toxicity of mixtures of contaminants.

\section{$3.4 \quad$ EVALUATION OF INTERIM ACTION OPPORTUNITIES}

Because access to the San Juan River floodplain is limited by fencing, no interim actions have been identified for the Shiprock site. Periodic maintenance of the fence should be conducted to continue restricting access of humans and livestock to the floodplain. 


\subsection{GROUND WATER COMPLIANCE STRATEGY SELECTION}

This section defines the ground water compliance strategy options, identifies the most likely ground water compliance strategies for the Shiprock site, explains the application of site-specific data to the ground water compliance selection framework, and analyzes possible deviations from the conceptual model, contingencies (alternatives to the compliance strategies), and decision rules (criteria) for application of contingencies.

\subsection{GROUND WATER COMPLIANCE STRATEGY}

Recommended ground water compliance decisions at the Shiprock site were made by using the compliance selection framework shown in Figures 4.1 and 4.2. This compliance selection framework was developed in the PEIS for the UMTRA Ground Water Project. The most likely ground water compliance strategies are selected by applying currently known site-specific data to the framework. The three possible compliance strategies specified in the compliance selection framework are:

- No remediation - Application of the no remediation strategy would mean that compliance with the EPA standards would be met without altering the ground water or cleaning it up in any way. This could be applied at sites that have no contamination above MCLs or background levels, or at sites that have contamination above MCLs or background levels but qualify for supplemental standards or ACLs.

- Natural flushing - Natural flushing allows for the natural ground water movement and geochemical processes to decrease the contaminant concentrations to levels within regulatory limits within a given time period. This could be applied at sites where ground water compliance would be achieved with the application of natural flushing within 100 years, where effective monitoring and institutional controls could be maintained, and if the ground water is not currently and is not projected to be a drinking water source.

- Active ground water remediation - Active ground water remediation would require the application of engineered ground water remediation technologies such as gradient manipulation, ground water extraction and treatment, and in situ ground water treatment to achieve compliance with the EPA standards.

\subsection{SITE-SPECIFIC GROUND WATER COMPLIANCE STRATEGIES}

Two separate ground water compliance strategies corresponding to each system for the Shiprock site (the terrace system and the floodplain system) are evaluated by applying the site-specific information from Section 3.0 to the compliance selection framework. 
CHARACTEAIZE PLUME AND HYDROLOGICAL CONDITIONS USING EXISTING DATA AND NEW DATA AS REQUIRED.

\section{IS GROUND WATER CONTAMINATION PRESENT IN EXCESS OF MAXIMUM CONCENTRATION LIMITS OP BACKGROUND?}

YES

\section{$80 \times 4$}

DOES CONTAMINATED GROUND WATER QUALIFY FOR SUPPLEMENTAL STANDARDS DUE TO LIMITED-USE GROUND WATER?

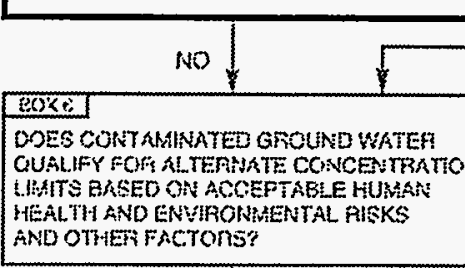

NO

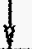

\section{$30 \times 5$}

AAE HUMAN HEALTH AND

ENVIRONMENTAL RISKS OF APPLYING

SUPPLEMENTAL STANDARDS ACCEPTABLE?
NO SITE-SPECIFIC GROUND WATER FENBECIXTION.

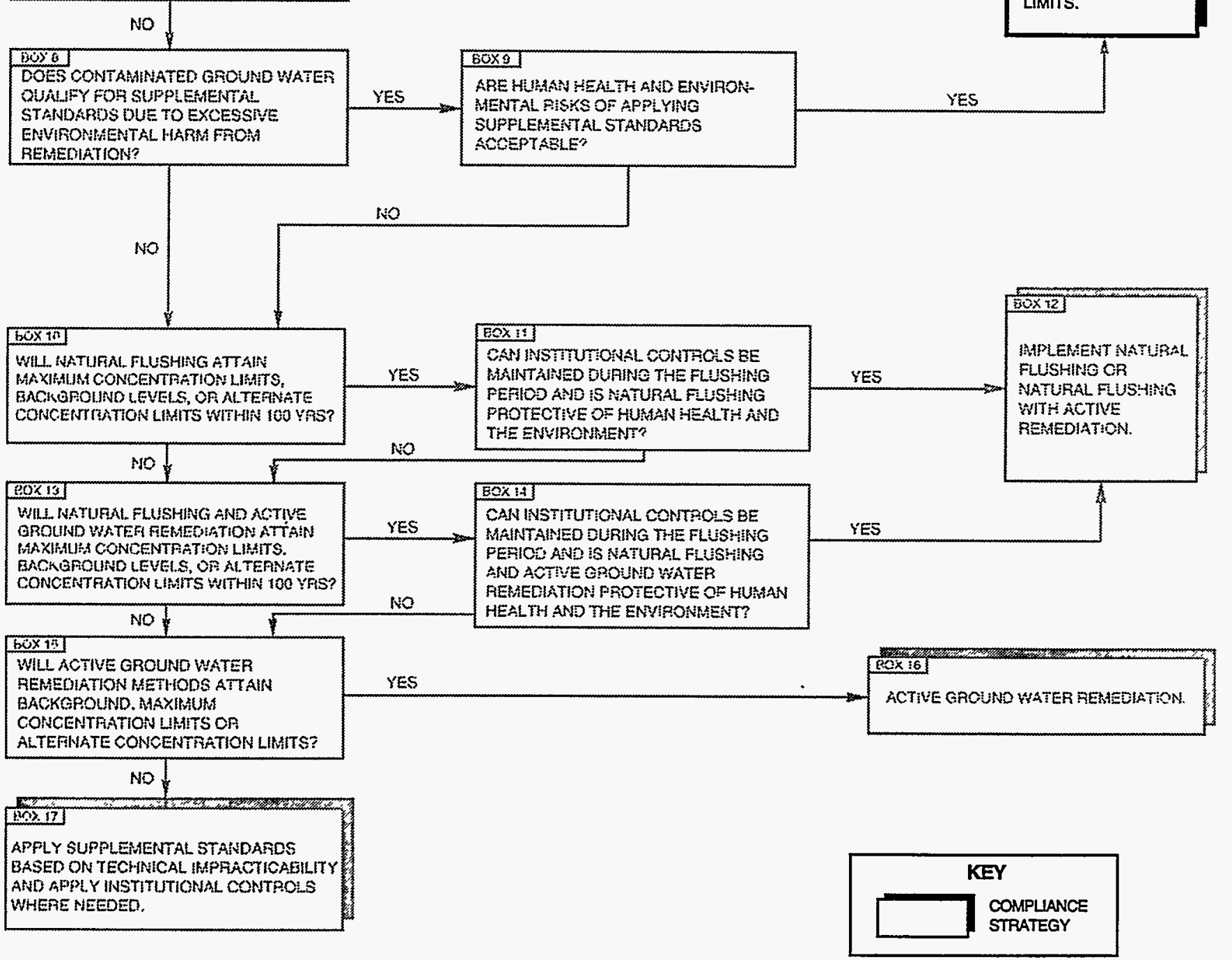

FIGURE 4.1

SHIPROCK TERRACE COMPLIANCE SELECTION FRAMEWORK SHIPROCK, NEW MEXICO, SITE 


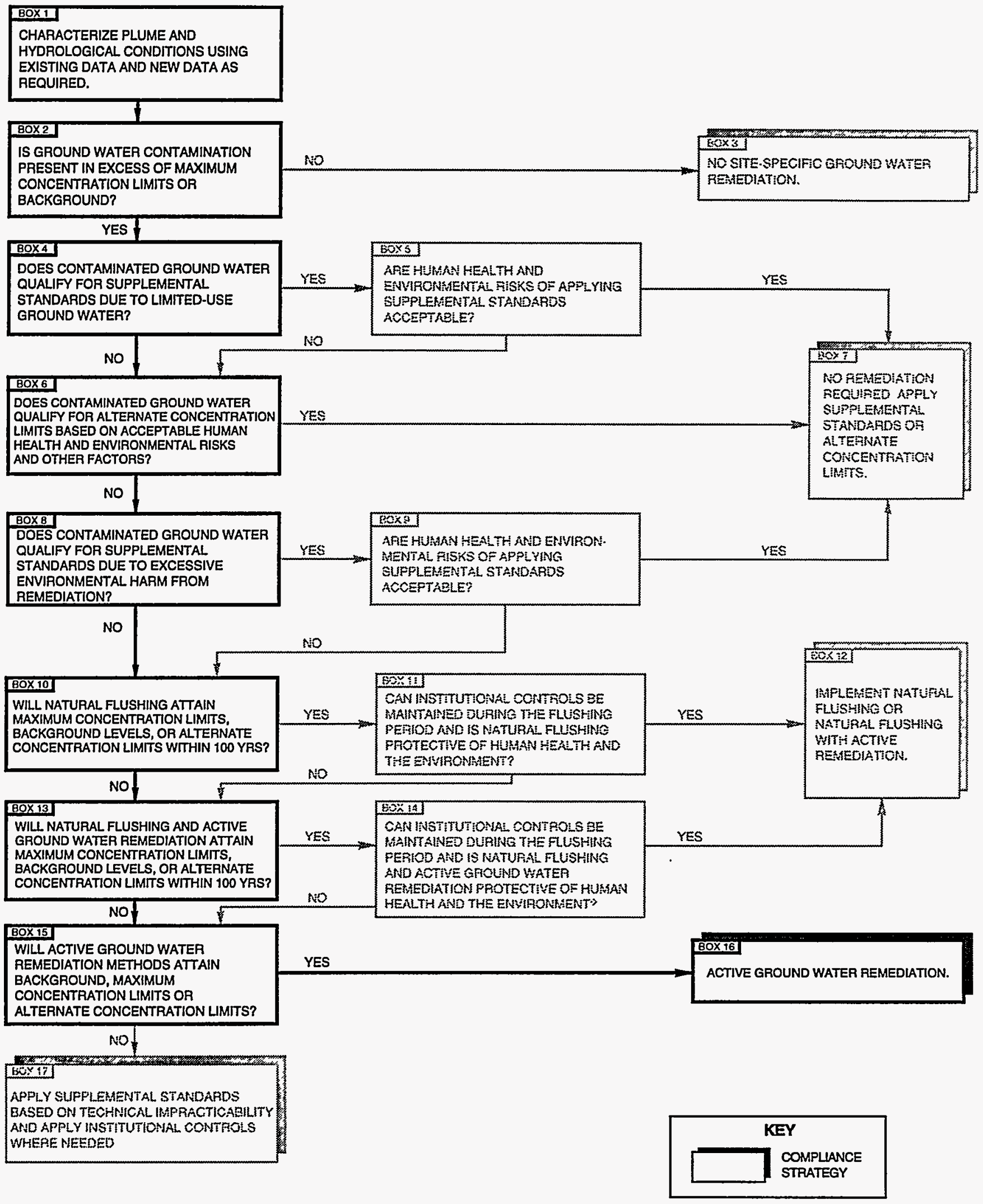

FIGURE 4.2

SHIPROCK FLOODPLAIN COMPLIANCE SELECTION FRAMEWORK SHIPROCK, NEW MEXICO, SITE 
The most likely compliance strategy for the ground water in the terrace aquifer would be no remediation with application of supplemental standards based on limited-use ground water. The most likely compliance strategy for the contaminated water in the floodplain aquifer is active remediation for the identified contaminants of potential concern.

Analysis of ground water quality of the two contaminated ground water systems has revealed 19 constituents present in the ground water at the site that either exceed MCLs or background levels (box 2 in Figure 4.1). These constituents are ammonium, antimony, arsenic, boron, cadmium, calcium, chloride, magnesium, manganese, nickel, nitrate, phosphate, potassium, selenium, sodium, strontium, sulfate, uranium, and zinc. The application of each of these constituents to the compliance selection framework is shown in Figure 4.3. The presence of elevated levels of these constituents appears to be a direct result of past uranium milling operations.

The compliance selection framework was applied to the site-specific conditions present at the terrace and at the floodplain to determine the most likely compliance strategies. The following sections describe the justification for selecting these recommended strategies.

\subsubsection{Terrace compliance strategy}

After analysis of site-specific conditions at the terrace, it was determined that compliance with the proposed standards could be achieved for the ground water by applying supplemental standards, since the ground water beneath the terrace should qualify as limited-use ground water based on low yield (box 4 in Figure 4.1). The terrace aquifer is not expected to be capable of sustaining a well yield of $150 \mathrm{gal}(570 \mathrm{~L})$ or more per day. It was determined that applying supplemental standards in this situation would protect human health and the environment, as there is no risk from exposure (box 5 in Figure 4.1 ) because the ground water is not a viable resource. Thus, the most likely compliance strategy for the terrace system is to conduct no site-specific remediation (box 7 in Figure 4.1) and apply for supplemental standards. The seeps at the escarpment are addressed in the floodplain compliance strategy (Section 4.2.2).

\subsubsection{Floodplain compliance strategy}

Analysis of the site-specific conditions at the floodplain indicates that the aquifer beneath the floodplain does not qualify as limited-use ground water (box 4 in Figure 4.2). Application of the conceptual model has shown that remediation of the floodplain aquifer for the 19 contaminants of potential concern detected at concentrations above background concentrations or MCLs will be more environmentally beneficial rather than harmful (box 8 in Figure 4.2).

Natural flushing is the next compliance strategy considered in the compliance framework. The time required for natural flushing depends on the location of the ground water recharge and discharge points and aquifer parameters such as 


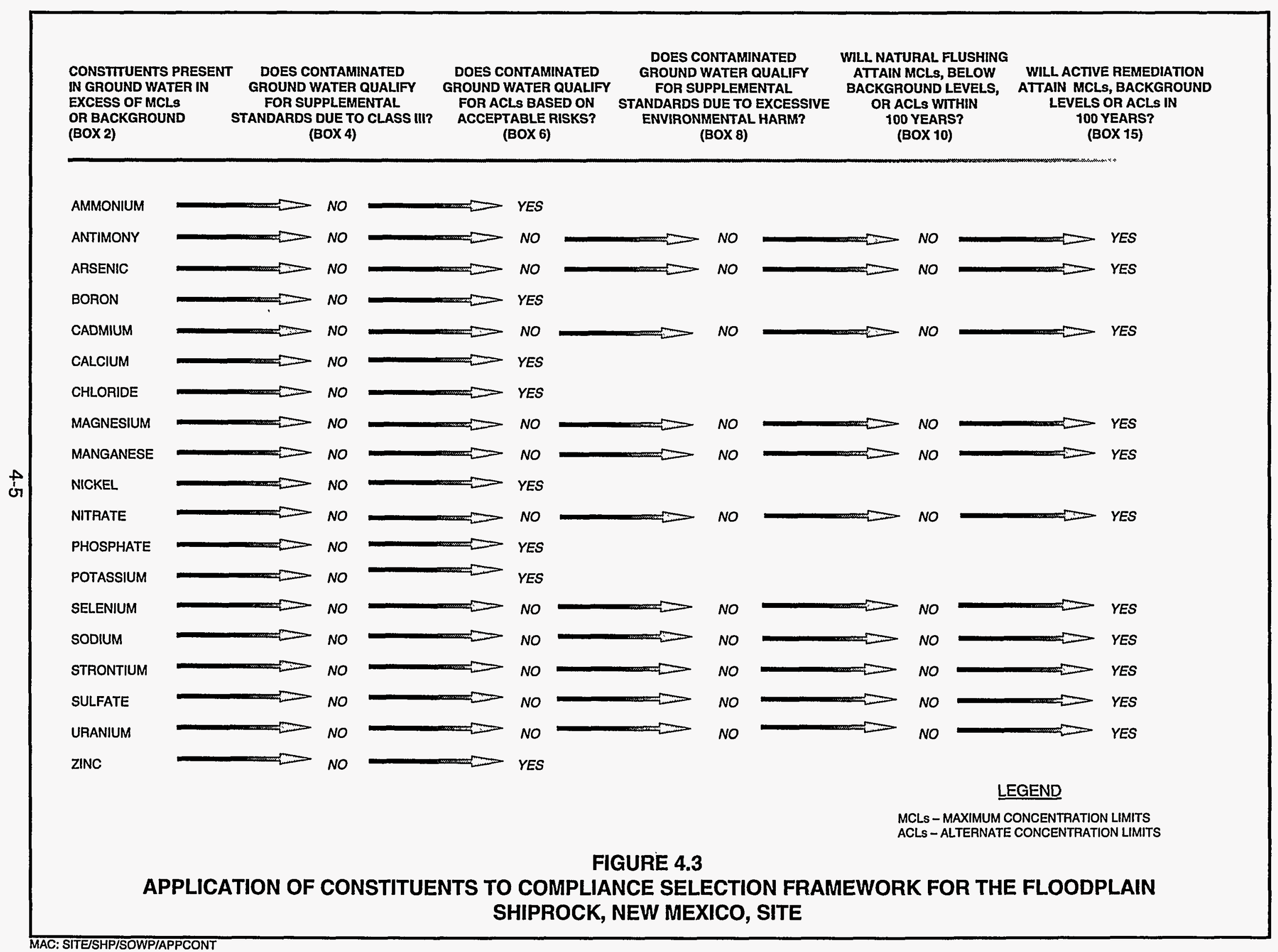


hydraulic gradient and effective porosity. Ground water in the alluvial aquifer is recharged from the San Juan River along the southeastern edge of the alluvial floodplain and discharges to the San Juan River along the northwestern edge of the floodplain. However, water quality data indicate the presence of contamination throughout the floodplain including locations in the vicinity of the recharge and discharge zones, a distance of about $3000 \mathrm{ft}(900 \mathrm{~m})$.

Considering that hydraulic conductivity for the floodplain aquifer can range from 5 to $300 \mathrm{ft} / \mathrm{day}(0.001$ to $0.1 \mathrm{~cm} / \mathrm{s})$ and the hydraulic gradient is approximately 0.002 ; one pore volume of water is estimated to require 14 to 800 years to flow the length of the aquifer. However, considering an intermediate hydraulic conductivity of $30 \mathrm{ft} /$ day $(0.01 \mathrm{~cm} / \mathrm{s})$, the residence time of ground water is approximately 140 years for one pore volume of ground water to flow along the entire length of the floodplain aquifer. Because of adsorption/desorption, differing residence times of contaminated ground water in micropores (dead pores), and variable rates of ground water flow, one pore volume is not sufficient to completely remove contamination from the aquifer (Domenico and Schwartz, 1990; Fetter, 1993). Therefore, if this intermediate value represents actual conditions in the alluvial floodplain, natural flushing will not be a viable compliance strategy.

Since the no remediation compliance strategy is not applicable and natural flushing is not likely to be a viable compliance strategy, the most likely compliance strategy is active remediation. The active remediation technologies being considered for remediation of the ground water in the floodplain alluvium include: pump and treat with discharge of the treated water back to the alluvial aquifer or to the San Juan River; use of permeable barriers; gradient manipulation; and nutrient uptake with vegetation.

Pump and treat technologies to be investigated include conventional water treatment technologies such as precipitation of metals through addition of chemicals; biological treatment systems for removal of ammonia and nitrates; and reverse osmosis-type processes for removal of salts (such as sulfates, nitrates, and chlorides), metals (such as uranium, calcium, sodium, and magnesium), and other dissolved substances. Selection of any treatment system will require engineering design studies including bench testing and pilot testing at the site. Water treatment processes such as these will produce waste streams requiring removal and appropriate disposal of these wastes off of the site.

Permeable barriers are materials placed in the ground to allow ground water to flow through the material. Often these materials are placed in a trench in the ground in such a manner to intercept the ground water flow. As the water flows through the permeable barrier material, biological and/or chemical reactions occur to remove the contaminants from the water. Contaminants such as metals will remain in the barrier material, while biologically degradable substances such as nitrates and sulfates will be chemically changed to less objectionable substances by the biological activity in the barrier. Bacteria in the permeable barrier that convert nitrates to nitrogen gas and sulfates to hydrogen 
sulfide are the same bacteria found in all soils and municipal wastewater treatment plants. Upon remediation of the ground water, the barrier material containing the bacteria and metal contaminants will be removed from the trench and disposed off of the site at an approved disposal site.

Gradient manipulation consists of increasing ground water flow through the aquifer by adding additional clean water to the ground water upgradient of the contamination to flush the contaminated water out of the floodplain aquifer. This could be done by diverting water from the San Juan River to the upgradient edge of the floodplain. Contaminants in the ground water in the Shiprock alluvial floodplain would be flushed into the San Juan River in the same manner that ground water is now being naturally flushed out of the alluvium, except at an accelerated rate.

Nutrient uptake with vegetation utilizes the ability of vegetation to remove nutrients such as nitrates from ground water to maintain plant growth. Along with nutrient removal, vegetation may also remove other ground water constituents such as iron, uranium, and sulfates. Vegetation now vigorously growing in the floodplain alluvium already may be remediating portions of the ground water for nitrates. Studies of existing vegetation and proposed vegetation should be completed before implementation of this technology for ground water remediation.

The ground water surfacing from the seeps does not qualify for supplemental standards because there are risks to human health and the environment, especially livestock that might graze on the floodplain. As described in Section 3.3.1, seeps from the terrace are feeding ponds on the floodplain. Therefore, the seeps and ponds will be considered part of the floodplain system and will be governed by the most likely ground water compliance strategy of active remediation for the floodplain. The remediation strategy would most likely be to isolate the seeps to eliminate the point of exposure and address the seep waters with the active remediation of the floodplain.

\subsection{DEVIATIONS, CONTINGENCIES, AND DECISION RULES}

Possible deviations from the conceptual model and the most likely compliance strategies have been identified for the terrace and floodplain aquifers. Contingencies and decision rules have been identified for each possible deviation.

\subsubsection{Terrace aquifer}

\section{Deviations}

Deviations from the conceptual model may occur if testing shows that there is a natural aquifer on the terrace capable of sustaining a yield of more than $150 \mathrm{gal}$ $(570 \mathrm{~L})$ per day. 


\section{Contingencies}

The contingency for this deviation is to revise the ground water compliance strategy to apply supplemental standards based on the technical impracticability of active remediation on the terrace. The technical impracticability is based on the conceptual model of the terrace, which identifies the upper Mancos Shale as being highly weathered and fractured. There is no known technology capable of extracting sufficient pore volumes of ground water from such a formation in order to remove the contaminants of potential concern to below background levels or MCLs. Nor is there is any known technology capable of in situ remediation in such a formation. Additional characterization would be necessary to demonstrate the appropriateness of this compliance strategy.

\section{Decision rules}

The decision rule for this contingency is based on aquifer tests conducted in background monitor wells that will be installed on the terrace away from the mound of contaminated process water. If tests show that the aquifer can sustain a yield of more than $150 \mathrm{gal}(570 \mathrm{~L})$ per day, additional characterization will be necessary to determine the appropriate compliance strategy.

\subsubsection{Floodplain aquifer}

\section{Deviations}

Deviations that may alter the recommendation of a remediation technology for the floodplain aquifer are those alluvial characteristics that do not correspond to the site conceptual model. Some of the deviations are:

- Variations in hydraulic transport.

- Density stratification in the ground water preventing the displacement of contaminated ground water in the deeper part of the alluvial aquifer.

- Presence of highly varying aquifer matrix properties both horizontally and vertically.

- Identification of the location, magnitude, and duration of seeps from the alluvial aquifer.

- Uptake of metals in vegetation grown over contaminated alluvial aquifer.

\section{Contingencies}

The contingencies for these possible deviations will be to modify the conceptual model and determine the impact of these deviations on the various recommended remediation technologies under consideration. 


\section{Decision rules}

The decision rules for selecting among the contingencies in the event that the conceptual model needs to be changed will be developed in concurrence with the specific contingencies. 


\subsection{DATA COLLECTION AND ASSESSMENT}

A variety of data collection activities are addressed to evaluate the effectiveness of the most likely compliance strategies to protect human health and the environment at the Shiprock site. The objectives of these data collection activities are presented in Section 5.1. The data needs that must be satisfied by the data collection activities and how they relate to the DCOs are presented in Section 5.2. Details of these activities and the DQOS are presented in Section 5.3.

\subsection{DATA COLLECTION OBJECTIVES}

The objectives of the data collection activities for the Shiprock site are to:

- Define the horizontal and vertical extent of contamination in ground water at the site.

- Characterize aquifer properties for the terrace and floodplain systems.

- Define biological and geochemical processes in the terrace and floodplain aquifers.

The horizontal and vertical extent of contamination in ground water needs to be defined to determine if levels of contaminants in ground water represent a risk to human health and the environment and to verify that the remediation technology for the floodplain will perform as designed.

Aquifer properties need to be thoroughly characterized to determine if the terrace aquifer can be considered as a limited-use aquifer (sustained yields less than $150 \mathrm{gpm}$ [570 L/min]), to help in the design of a remediation method for the floodplain, and to determine the degree of hydraulic interconnection among the terrace aquifer, the floodplain aquifer, and the San Juan River.

The biological and geochemical processes in the aquifer need to be defined to determine the amount of aquifer remediation taking place by natural processes, and to help in the design of an active remediation method for the floodplain, or the alternatives identified as contingencies.

\subsection{STATEMENT OF DATA NEEDS}

The existing site information indicated data needs that must be evaluated to define more accurately and support the most likely ground water compliance strategies and evaluate the feasibility of potential ground water remediation technologies. 
The data needs for defining the horizontal and vertical extent of contamination in ground water are:

- Determining the concentration of contaminants of potential concern in ground water at the site.

- Measuring the specific conductance of ground water in the floodplain aquifer.

- Determining the structure of the top of the Mancos Shale for the terrace and the floodplain.

- Determining directions of ground water flow in the terrace and floodplain aquifers.

The data needs for characterizing aquifer properties are:

- Measuring the hydraulic properties of the lithologic units and the nature of fractures in the Mancos Shale.

- Determining the ground water flow relationships of the terrace, floodplain, and San Juan River.

- Determining the sustainable yield of ground water from the terrace aquifer.

- Measuring the amount of water flowing from the seeps on the escarpment.

- Estimating the amount of water recharging the floodplain aquifer from the artesian well.

- Determining ground water flow velocities at the site.

The data needs for defining biological and geochemical processes in the aquifer are:

- Determining the rate of biological and geochemical properties affecting breakdown or attenuation of contaminants of potential concern in ground water.

- Calculating site-specific retardation factors and distribution coefficients for the contaminants of potential concern.

\subsection{DATA COLLECTION ACTIVITIES AND QUALITY OBJECTIVES}

Data collection activities have been identified that will ensure that the data collected will be sufficient to satisfy the objectives outlined above. DQOs are quantitative and qualitative statements made to ensure that data of known and appropriate quality are obtained during an investigation. To ensure that the data 
gathered during investigation activities are adequate to support stakeholder decisions, a clear definition of the objectives and the method by which decisions will be made will be established. These determinations are facilitated by the development of DQOs.

The data to be gathered from each data collection activity and the quality objectives are discussed in the following sections.

\subsubsection{Surface geophysical surveys}

An electromagnetic (EM) survey will be conducted to establish bounds on the contaminant plume on the floodplain and on the terrace. Data from this survey will be used to assist in determining locations for new monitor wells and to establish the target area to be remediated.

Depths to the top of the Mancos Shale may be determined for the terrace with transient electromagnetic (TEM) methods; however, the expected depths to the Mancos Shale are at the low end of the optimal range for TEM methods. Modeling of the terrace geology will be conducted prior to the start of any geophysical field work. If the modeling shows that TEM methods are not appropriate for the site, other methods, such as seismic refraction or resistivity soundings, will be used.

Depths to the top of the Mancos Shale will be determined for the floodplain with either seismic refraction or resistivity soundings.

\section{Surface electromagnetic ground conductivity survey}

Surface EM ground conductivity surveys will be performed on the terrace and floodplain using EM34 instrumentation. Because of the more complex geology of the terrace, the EM34 method may not be appropriate; however, test soundings will be conducted on the terrace to determine the effectiveness of the instrument in this area. The grid for the EM34 survey will be determined in the field to take into consideration influences of natural conditions and to coordinate with monitor well locations to take advantage of correlation of data collected during the borehole fluid specific conductance survey.

The EM34 survey lines will be run parallel to the topography for optimum results. The location and configuration of the water table will also need to be considered in conducting the survey. Results of the EM34 survey will be used to determine the lateral extent of ground water contamination based on conductivity differences in the ground water.

\section{Surface transient electromagnetic soundings survey}

Based on information from initial geophysical surveys and modeling, areas of interest will be selected for geophysical investigation using surface TEM 
methods. EM47 instrumentation will be used to delineate the vertical extent of contamination in ground water and the top of the Mancos Shale.

Locations for the EM47 surveys will be selected within and near the edges of the area of contaminated ground water to determine the vertical extent of siterelated contamination. These locations will be determined in the field, based on results of the other geophysical surveys. Measurements will be made at selected locations, and the depth of investigation will be determined by the size of the surface transmitter loop.

Interpretation of TEM sounding data will provide the depth, thickness, and conductivity of subsurface layers with different electrical conductivities. Soundings made along a straight-line traverse will provide a cross-sectional view of the area of ground water contamination.

\section{Data quality objectives for surface electromagnetic surveys}

The proposed areal coverage of the geophysical surveys is shown in Figure 5.1. The geophysical surveys will be limited to a depth of approximately $50 \mathrm{ft}$ $(15 \mathrm{~m})$. Geophysical data will be generated, verified, and documented in compliance with the UMTRA Project Quality Assurance Implementation Plan (DOE, 1994b). Geophysical data will be collected in accordance with the instrument manufacturer's specifications and standard field operating procedures. Results of the geophysical investigations will be evaluated using industry-approved methods and standard operating procedures (SOP). Adherence to these practices will ensure that the data collected will be of sufficient quality to support the DCOs outlined above. These procedures will locate the lateral edge of the contaminant zone in ground water to within approximately $100 \mathrm{ft}(30 \mathrm{~m})$ and the vertical extent to within approximately $5 \mathrm{ft}$ $(2 \mathrm{~m})$.

The surface EM survey will be done with a Geonics EM34 tool (or equivalent). The EM34, can be set to focus on various depths depending on orientation and spacing of the coils. For the floodplain survey, the instrument would be set up to investigate no more than $20 \mathrm{ft}(6 \mathrm{~m})$ in depth to minimize the influence of variations in the elevation of the Mancos Shale. Horizontal resolution of measurements with this instrument should be within approximately $100 \mathrm{ft}$ $(30 \mathrm{~m})$, depending on physical conditions beneath the site. This method is sensitive to clay layers, which normally have an elevated electrical conductivity. Data from the EM34 survey will be used to provide information on the conductivity of clay layers relative to the conductivity of zones of contaminated ground water. If EM34 instrumentation is used on the terrace, it will measure the differences between the conductivity of the Mancos Shale and the overlying alluvium. Variables in the hydrogeologic system must be considered during data interpretation to verify the assumption that the contrast in conductivity in ground water is the dominant influence on the data. 


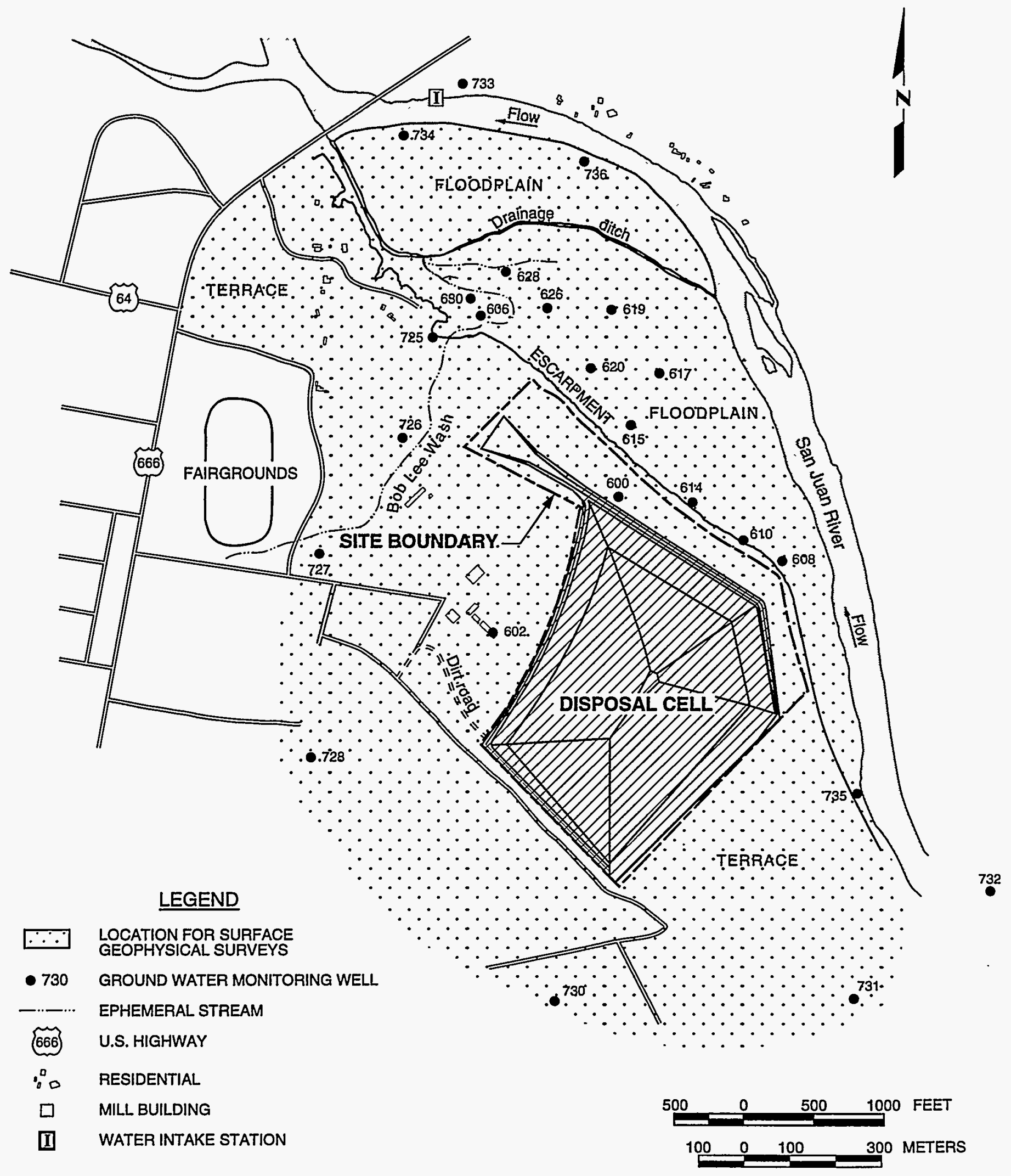

FIGURE 5.1

LOCATION FOR SURFACE GEOPHYSICAL SURVEYS SHIPROCK, NEW MEXICO, SITE 
The surface TEM soundings method (Geonics EM47 or equivalent) provides a means of determining the vertical changes in electrical conductivity correlating with differences in soil and rock layers and variations in the conductivity of fluids filling the pore spaces. Vertical resolution of measurements using EM47 equipment should be within 5 to $10 \mathrm{ft}(1.5 \mathrm{to} 3 \mathrm{~m})$ of a contact between contrasting conductivities. Such soundings are optimal in the depth range from about 30 to $300 \mathrm{ft}(10$ to $100 \mathrm{~m})$.

\subsubsection{Borehole fluid conductivity surveys}

This activity will consist of taking in situ conductivity measurements of water in all accessible monitor wells to investigate the possibility of mill process fluids of greater densities than natural ground water remaining in low spots within the floodplain aquifer.

\section{Data quality objectives for borehole fluid conductivity survey}

The borehole fluid conductivity survey will be conducted using a YSI Model $6000 i$ multiparameter water quality monitor (or equivalent). Readings will be taken in each well every $0.5 \mathrm{ft}(15 \mathrm{~cm})$ over the screen interval. Readings will be taken for specific conductivity, DO, reduction-oxidation potential, $\mathrm{pH}$, and temperature.

\subsubsection{Core analysis}

Laboratory analysis of new and archived core samples is proposed to determine hydraulic conductivity, porosity, bulk density, specific yield, and grain size distribution of the lithologic units that can be cored. These analyses will provide more detailed small-scale information on aquifer characteristics than the pumping test results. Grain size analyses from the core samples are needed to determine the most efficient filter pack and screen slot size for new wells.

\section{Data quality objectives for core analysis}

Samples from the cores will be analyzed by a geotechnical engineering laboratory. Application of UMTRA Project SOP 15.2.2 (JEG, n.d.), "Laboratory Testing of Borehole Samples of Rock and Soil," will ensure that adequate procedures are followed.

\subsubsection{Monitor well installation}

The preliminary EM survey will provide a semiquantitative estimate of plume configuration. However, direct sampling will be necessary to confirm the actual constituent concentrations in ground water. The installation of additional monitor wells is contingent upon the results of the preliminary EM survey and the core analysis to help select gravel pack and screen size. 
It is proposed that up to twelve 4-inch $(10-\mathrm{cm})$ diameter monitor wells be installed on the site. The monitor wells will be drilled and installed to provide access for water quality sampling for further plume definition, pumping tests for aquifer characterization, and water level measurements for defining ground water flow directions. The wells will be drilled and completed in accordance with UMTRA Project SOPs (JEG, n.d.).

Four monitor wells are planned to be installed in the terrace. Two of these monitor wells will be drilled to provide background ground water quality data and to characterize aquifer properties. The other two monitor wells will be drilled near the escarpment to measure aquifer properties, water levels, and water quality in the fractured and weathered Mancos Shale.

Eight monitor wells will be installed on the floodplain. The monitor well locations and depths may change based on the results and interpretations obtained from the surface geophysical and fluid conductivity surveys. One of the floodplain monitor wells will be screened within the fine-grained alluvium. At least three of the monitor wells will be screened within the coarse-grained alluvium, and at least three monitor wells will be screened in the top of the Mancos Shale to measure aquifer properties, water levels, and water quality in the fractured and weathered Mancos Shale.

Core samples from at least one monitor well on the floodplain will be collected starting $5 \mathrm{ft}(1.5 \mathrm{~m})$ above the water table and progressing to the total depth of the borehole for the purposes of geochemical analysis as described in Section 5.3.8.

Lithologic descriptions will be compiled from borehole cuttings collected during monitor well installation. These cuttings may enhance the understanding of the site geology and the conceptual model.

\section{Data quality objectives for monitor well installation}

The results of the preliminary EM survey will be used to locate monitor wells where they can best quantify actual levels of contamination and further define the ground water flow field. The wells will be 4 inches $(10 \mathrm{~cm})$ in diameter with screens located to optimally detect the plume as indicated by the geophysics or to measure aquifer properties of the various lithologies present at the site. Construction of these wells according to UMTRA Project SOPs (JEG, n.d.) will ensure that the wells will be adequate for the intended purpose. These wells will be constructed with polyvinyl chloride materials.

\subsubsection{Piezometer installations}

Six piezometers will be installed on the floodplain close to and along the length of the San Juan River to measure head differences between the river and ground water. Three piezometers will be installed in Bob Lee Wash within the area affected by flow from the artesian well to measure the influence of water 
flowing from the artesian well into the floodplain aquifer. The piezometers will consist of 2-inch $(5-\mathrm{cm})$ diameter steel well points driven to at least $2 \mathrm{ft}(0.6 \mathrm{~m})$ below the water table. Staff gauges will be installed in the river near each piezometer so that water levels can be measured in the river at the same time that measurements are made in the piezometers. A weir will be installed to measure the surface portion of the flow in Bob Lee Wash.

\section{Data quality objectives for piezometer installations}

To ensure accuracy of water level measurements taken from the piezometers, the elevations of the tops of the piezometers, staff gauges, and monitor wells will be surveyed by a certified civil surveyor. The surveyor will certify that the elevations relative to MSL are accurate to plus or minus $0.01 \mathrm{ft}(0.3 \mathrm{~cm})$ or better. Water levels measured in the piezometers, staff gauges, and monitor wells will be measured to within $0.02 \mathrm{ft}(0.6 \mathrm{~cm})$.

\subsubsection{Aquifer testing}

Short-term and long-term aquifer testing will be conducted in selected monitor wells to quantify more accurately the aquifer properties necessary to design an effective remediation system.

The results of the core analysis and existing slug test data will be used to complete the preliminary test design. However, well efficiency cannot be accounted for in the design because it is a parameter that can only be measured in the field. Prior to performing any pumping tests, step drawdown tests lasting about 3 hours each will be performed in each monitor well selected for testing to estimate the optimum pumping rate to be used in the long-term tests. A minimum of three changes in pumping rate will be made.

Following the analysis of the step tests, short-term tests in the form of single well drawdown and recovery tests will be conducted. This will confirm that the general test design (pumping rate and time) is adequate. The results of the first three short-term tests will be evaluated. If there is less than half an order of magnitude of variation in the results, no further short-term tests will be performed.

Long-term pumping tests will be conducted in the two background terrace monitor wells and in existing terrace monitor well 728 . Long-term pumping tests will be conducted in at least three new monitor wells on the floodplain. These wells will be selected so that each of the three lithologies on the floodplain will be tested. The tests will be run long enough so the effects of delayed yield occur. This phase of aquifer response will be analyzed with Neuman's Method (Neuman, 1975). This method allows horizontal-to-vertical anisotropy to be assessed directly. At least one of the short-term tests should be done in a well that will be used for the long-term test to allow checking and cross correlation of the results of the tests. A similar test was performed at another UMTRA Project site that has similar hydraulic properties, requiring 
81 hours at about $1.5 \mathrm{gpm}(6 \mathrm{~L} / \mathrm{min})$ to give the desired results. Shiprock will likely have similar requirements in terms of flow rate and duration.

\section{Data quality objectives for aquifer testing}

Short-term and long-term aquifer test analyses are recommended to determine: 1) the spatial distribution of hydraulic conductivity, 2) how the aquifer responds to conditions similar to those that may be imposed with active remediation, and 3) the effectiveness of the most likely compliance strategies using core and existing slug test data to provide a sufficient data base. Standard data loggers and pressure transducers used in accordance with the manufacturers' instructions will produce reliable data for the analysis. Tests will be designed and analyzed according to various standards, such as American Society for Testing Materials (ASTM) standard D4050-1991, "Standard Test Method (Field Procedure) for Withdrawal and Injection Well Tests for Determining Hydraulic Properties of Aquifer Systems."

The short-term tests will be run long enough so that the effects of delayed yield are evident, and then analyzed with Neuman's Method (Neuman, 1975).

For improved accuracy, each test will be analyzed during both the drawdown and recovery phases to cross-check the results. The reasonableness of the test results can be also checked with the core analysis and existing slug test data. The step tests allow estimation of specific capacity (from which transmissivity and hydraulic conductivity can be derived) and well efficiency. Knowledge of these parameters will allow fine tuning of the test in the field to produce optimum results.

\subsubsection{Water quality sampling and analysis}

Water quality samples will be collected and water levels measured at the new and existing monitor wells. Samples will be analyzed for both organic and inorganic constituents. The purpose of the analysis is to define quantitatively the lateral and vertical extent of ground water contamination in the terrace and floodplain aquifers. Samples will. also be analyzed for contaminants of potential concern, including antimony, arsenic, cadmium, magnesium, manganese, nitrate, selenium, sodium, strontium, sulfate, and uranium, and other parameters of interest such as TDS, dissolved organic carbon, and other select organic constituents.

Field analyses for pH, Eh, DO, specific conductance, turbidity, and temperature will be performed. Laboratory chemical analysis data are validated according to the UMTRA Project data validation procedure. The activities that comprise this procedure are verification of: 1) sample chain-of-custody maintenance, 2) analysis performance within applicable holding times, 3) quality control sample analyses and results meeting specified criteria, and 4) data passing comparative tests with historical data. Additionally, UMTRA Project TAC subcontract laboratories are required to maintain the full range of supporting documentation (Level D) required for legal data defensibility in their case files. 
Thus, chemical analysis data meet HAZWRAP Level $C$ requirements and exceed those requirements in the areas of documentation requirements and computerized identification of suspected anomalies.

Data quality objectives for water quality sampling and analysis

Each well, including the new monitor wells, will be sampled in accordance with the water and sampling analysis plan for the Shiprock site (DOE, 1994c). Samples will be collected, preserved, and shipped according to the UMTRA Project SOPs (JEG, n.d.). Samples will be analyzed according to the statement of work (TAC, 1993) for the UMTRA project.

The need for sampling and analyzing the major ions and field parameters is based on two aspects: 1) some of the constituents (e.g., sulfate and uranium) provide an indication of plume behavior and 2) the ground water should be sufficiently well characterized to calculate saturation indices and speciation of the major mineral phases and dissolved constituents likely to occur in the system. The precipitation or dissolution of solid phases may affect the migration rate and concentration of the contaminants.

\subsubsection{Geochemical analysis of lithologic samples}

Core and cuttings samples collected from several of the new monitor wells will be analyzed for mineralogy, cation and anion exchange, sorption potential for select constituents, and other pertinent geochemical parameters that influence and control chemical reactions in the subsurface. These reactions can potentially reduce contaminant concentrations in ground water and need to be understood. The samples will also be batch tested for adsorption properties for the contaminants of potential concern. Results of these analyses will be used to calculate site-specific retardation factors and distribution coefficients.

\section{Data quality objectives for geochemical analysis of subsurface samples}

Fresh samples will be used rather than the archived samples because it is not known what changes may have occurred to the cores during the last several years of storage. Use of standard testing procedures (such as ASTM Method 4319, "Distribution Ratios by the Short-Term Batch Method") and standard laboratory quality assurance procedures will generate data suitable for this activity.

\subsubsection{Biological sampling of ground water}

Biological samples will be collected to define the bacteria population in the aquifer and to test the potential for bacteria to reduce and immobilize contaminants in the floodplain aquifer. Bacteria will be isolated from ground water samples collected under an anoxic environment using special procedures and techniques. This information is necessary to design the recommended biological barrier system for remediation of the floodplain aquifer and to determine the potential for natural processes in the remediation of ground water. 
Data quality objectives for biological sampling of ground water

These samples will be analyzed by the research group at the University of New Mexico. Standard techniques will be used as guidelines to sample, preserve, and ship biological samples. Researchers at the University of New Mexico will use standard analytical techniques to enumerate, isolate, and test the nutritional response of bacteria in ground water samples.

\subsubsection{Surface water and sediment sampling}

Surface water and sediment sampling from the San Juan River and wetland areas on the San Juan River floodplain is required to assess the impact of ground water discharge into the river and wetlands. Sampling should be conducted during a low-flow period in the river. The samples will be analyzed for the same suite of analytes that will be used for analysis of ground water samples from monitor wells.

\section{Data quality objectives for surface water and sediment resampling}

The most recent round of surface water and sediment samples collected during a high-flow period from the San Juan River and the water bodies on the San Juan River floodplain provided inconclusive results. No recent sampling has been conducted in the San Juan River and wetland area during a seasonal lowflow period in the river. Because the potential for contaminated ground water discharging to the river and these water bodies cannot be conclusively ruled out, samples of water and sediment samples will be collected during a low-flow period when the dilution effects associated with the high-flow water conditions are expected to be minimal. The samples will be collected in accordance with UMTRA Project SOPS and developed for the complete suite of analytes.

\subsection{RESULTS AND EVALUATION OF DATA COLLECTION ACTIVITIES}

Upon completion of the data collection activities, Revision 1 of the SOWP will be prepared. Revision 1 will include all previously existing ground water data for the site, a discussion of all field activities, a description of the instrumentation used, the location of the surveys, copies of all field measurement data, copies of field logs, methods of interpretation, and a summary of the results relative to the DCOs.

After completion of the data collection activities, it is proposed that a detailed numerical ground water flow model be constructed that will integrate all the available information about the site. The model will also allow quantitative evaluation of the flow rates required to meet the selected remedial strategy and the possible effects of the uncertainties in the conceptual model (e.g., how well connected to the flow system of the San Juan River is the floodplain aquifer?). The ground water flow model will be used to help design the biological barrier system. 


\subsection{LIST OF CONTRIBUTORS}

The following individuals contributed to the preparation of this report.

\begin{tabular}{ll}
\hline Name & Contribution \\
\hline B. Smith & Principal author \\
B. Smith & Hydrogeology \\
A. Groffman & Geochemistry \\
G. Hartmann & Engineering \\
B. Malczewska-Toth & Risk assessment \\
R. Neri Zagal & Regulatory compliance \\
C. Burt, J. Gibb, A. Holm & Peer reviewers \\
R. Bennett, R. Bowen, P. Briggs & Senior technical reviewers \\
L. Sanchez & Word processing \\
T. Gagliano, J. Gates, B. Harvey & Graphic design \\
J. Bartel; K. Walston & Technical editing \\
R. Meyers; R. Neri Zagal & Document coordinator \\
\hline
\end{tabular}




\subsection{REFERENCES}

AEC (Atomic Energy Commission), 1960. AEC Radiation Control Program for Uranium Mill Operations, May 1960, p.11.

Allison et al. (J. D. Allison, D. S. Brown, K. J. Novo-Gradac) 1991. MINTEQA2/ PRODEFA2, A Geochemical Assessment Model For Environmental Systems: Version 3.0 User's Manual, EPA/600/3-91/021.

CSU (Colorado State University), 1982. "Characterization of Inactive Uranium Mill Tailings Sites: Shiprock, New Mexico," draft, Fort Collins, Colorado.

Dames and Moore, 1982. "Feasibility Evaluation On-Site Stabilization of Uranium Mill Tailings, Shiprock, New Mexico," draft, job no. 10850-059-14, Phoenix, Arizona.

DOC (U.S. Department of Commerce), 1990. 1990 Census of Population, General Population for New Mexico, CPK-1-46, U.S. Department of Commerce, Economics and Statistics Administration, Bureau of Census, Washington, D.C.

DOE (U.S. Department of Energy), 1995. "Draft Programmatic Environmental Impact Statement for the Uranium Mill Tailings Remedial Action Ground Water Project," April 1995, prepared by the U.S. Department of Energy, UMTRA Project Office, Albuquerque Operations Office, Albuquerque, New Mexico.

DOE (U.S. Department of Energy), 1994a. Baseline Risk Assessment of Ground Water Contamination at the Uranium Mill Tailings Site Near Shiprock, New Mexico, DOE/AL/62350-48F, REV. 1, U.S. Department of Energy, UMTRA Project Office, Albuquerque Operations Office, Albuquerque, New Mexico.

DOE (U.S. Department of Energy), 1994b. UMTRA Project Technical Assistance Contractor Quality Assurance-Implementation Plan, DOE/AL/62350-72D, March 1994, prepared by the U.S. Department of Energy, UMTRA Project Office, Albuquerque Operations Office, Albuquerque, New Mexico.

DOE (U.S. Department of Energy), 1994c. UMTRA Project Water Sampling and Analysis Plan, Shiprock, New Mexico, DOE/AL/62350-78, REV. 0, US Department of Energy, UMTRA Project Office, Albuquerque Operations Office, Albuquerque, New Mexico.

DOE (U.S. Department of Energy), 1993a. Technical Approach to Groundwater Restoration, DOE/AL/62350-20F, prepared by the U.S. Department of Energy, UMTRA Project Office, Albuquerque Operations Office, Albuquerque, New Mexico. 
DOE (U.S. Department of Energy), 1993b. Recommendations for the Preparation of Environmental Assessments and Environmental Impact Statements, Office of NEPA Oversight, U.S. Department of Energy, Washington, D.C.

DOE (U.S. Department of Energy), 1992. UMTRA Groundwater Project Plan, UMTRADOE/AL-62350-61, May 1992, prepared by the U.S. Department of Energy, UMTRA Project Office, Albuquerque Operations Office, Albuquerque, New Mexico.

DOE (U.S. Department of Energy), 1991. Escarpment Seeps at Shiprock, New Mexico, UMTRA-DOE/AL-350214.0000, June 1991, prepared by the U.S. Department of Energy, UMTRA Project Office, Albuquerque Operations Office, Albuquerque, New Mexico.

DOE (U.S. Department of Energy), 1985. Remedial Action Plan and Site Conceptual Design for Stabilization of the Inactive Uranium Mill Tailings Site at Shiprock, New Mexico, UMTRA-DOE/AL-050504.0000, June 1985, prepared by the U.S. Department of Energy, UMTRA Project Office, Albuquerque Operations Office, Albuquerque, New Mexico.

DOE (U.S. Department of Energy), 1984. Processing Site Characterization Report, UMTRA-DOE/AL-0042, 1984, prepared by the U.S. Department of Energy, UMTRA Project Office, Albuquerque Operations Office, Albuquerque, New Mexico.

Domenico, P. A., and F. W. Schwartz, 1990. Physical and Chemical Hydrogeology, John Wiley and Sons, 824 p.

FBDU (Ford, Bacon \& Davis Utah, Inc.), 1981. "Engineering Assessment of Inactive Uranium Mill Tailings, Shiprock Site, Shiprock, New Mexico," UMTRADOE/UMT-0104, FBDU 360-02, Uc-70, prepared by FBDU, Salt Lake City, Utah, for the U.S. Department of Energy, UMTRA Project Office, Albuquerque Operations Office, Albuquerque, New Mexico.

Fetter, C.W., 1993. Contaminant Hydrogeology, Macmillan Publishing Company, New York, New York.

Freeze, A. R. and J. A. Cherry, 1979. Groundwater, Prentice Hall, Inc., Englewood Cliffs, New Jersey, p. 604.

GECR (Geochemistry and Environmental Chemistry Research, Inc.), 1982. "Data for Geochemical Investigation of UMTRAP Designated Site at Shiprock, New Mexico," draft report prepared by G. Markos and U.J. Bush, Geochemistry and Environmental Chemistry Research Inc., Rapid City, South Dakota, for the U.S. Department of Energy, UMTRA Project Office, Albuquerque Operations Office, Albuquerque, New Mexico. 
Glikey, M.M., and R.M. Stotelmeyer, 1965. "Water Requirements and Uses in New Mexico Mineral Industries," U.S. Bureau of Mines Information Circular 8276. p. 34-35.

Goetz, C.L., and Abeyta, C.G., 1987. "Adequacy of NASQAN Data to Describe Areal and Temporal Variability of Water Quality of the San Juan River Drainage Basin Upstream from Shiprock, New Mexico," U.S. Geological Society Water Resources Investigation Report 85-4043, p.89.

Hans, J.M., 1977. EPA Las Vegas Facility, personal communication with H. Tso, Executive Director, Navajo Environmental Protection Commission, Window Rock, Arizona, UPDCC File Location No. 4.19.2.9, Albuquerque, New Mexico, July 13, 1977.

Hsi, C.D., and D. Langmuir, 1985. "Adsorption of Uranyl onto Ferric Oxyhydroxides: Application of the Surface Complexation Site-Binding Model," in Geochim. Cosmochim. Acta, Vol. 49, pp. 1931-1941.

Hunt, R.E., 1984. "Geotechnical Engineering Investigation Manual," McGraw-Hill Book Company, New York, New York, pp. 149-157.

JEG (Jacobs Engineering Group Inc.), n.d. Albuquerque Operations Manual, standard operating procedures, prepared by Jacobs Engineering Group Inc., Albuquerque, New Mexico, for the U.S. Department of Energy, UMTRA Project Office, Albuquerque Operations Office, Albuquerque, New Mexico.

Kent et al. (D.B. Kent, V.S. Tripathy, N.B. Ball, J.O. Leckie, and M.D. Siegel), 1988. Surface-Complexation Modeling of Radionuclide Adsorption in Subsurface Environments, NUREG/CR-4807, SAND86-7175, prepared for the Division of High-Level Waste Management Office of Nuclear Material Safety and Safeguards, U.S. Nuclear Regulatory Commission, Washington, D.C.

Leckie et al. (J.O. Leckie, M.M. Benjamin, K. Hayes, G. Kaufman, S. Altmann), 1980. Adsorption/Coprecipitation of Trace Elements From Water With Iron Oxide, EPRI CS-1513, Electric Power Research Institute, Palo Alto, California.

McLean, J.S., and I.A. Johnson, 1987. "Aquifers of the Western Mountain Area," American Water Resources Association Monograph Series, No. 14, pp. 203-217.

Merritt, R. C., 1971. The Extractive Metallurgy of Uranium, Colorado School of Mines Research Institute, prepared under contract with U.S. Atomic Energy Commission, Johnson Publishing Company, Boulder, Colorado.

Nakashima, Satoru, 1992. Complexation and Reduction of Uranium by Lignite, The Science of the Total Environment, 117/118, Elsevier Science Publishers B.V., Amsterdam, the Netherlands, pp. 425-437. 
Neuman, S.P., 1975. "Analysis of Pumping Test Data from Anisotropic Unconfined Aquifers Considering Delayed Yield," Water Resources Research, v. 11, no. 2, pp. 329-342.

NMBMMR (New Mexico Bureau of Mines and Mineral Resources), 1983. Hydrology and Water Resources of San Juan River Basin, New Mexico.

Public Health Service, 1962. "Stream Surveys in Vicinity of Uranium Mills, IV, Area of Shiprock, New Mexico - November 1960," Division of Water Supply and Pollution Control, Denver, Colorado, December 1962.

Rai, D., and J.M. Zachara, 1984. Chemical Attenuation Rates, Coefficients and Constants in Leachate Migration Volume 1: A Critical Review, EPRI-EA-3356, Volume 1, Battelle, Pacific Laboratories, Richland, Washington.

TAC, 1995. Review and Assessment of Variable Density Ground Water Flow Effects on Plume Formation at UMTRA Project Sites, January 1995.

TAC (Technical Assistance Contractor), 1993. "Statement of Work, UMTRA Project TAC General Inorganic and Radiochemical Analyses," prepared by Jacobs Engineering Group Inc., for the U.S. Department of Energy, UMTRA Project Office, Albuquerque Operations Office, Albuquerque, New Mexico.

Themelis, John G., 1986. Department of Energy (DOE) Project Manager, Uranium Mill Tailings Project Office, personal communication with James Oldham, Project Director, MK-Ferguson Company Inc., Albuquerque, New Mexico, UPDCC File Location No. 4.15.1.3, Albuquerque, New Mexico, August 26, 1986.

Thiers, G.R., 1986. Morrison-Knudsen Engineers, Inc., "Shiprock Remedial Action Case Study," presented at the U.S. Department of Energy Remedial Action Programs Conference, Oak Ridge, Tennessee, May 6, 1986.

\section{CODE OF FEDERAL REGULATIONS}

10 CFR Part 1021, "National Environmental Policy Act; Implementing Procedures and Guidelines Revocation; Final Rule and Notice," U.S. Department of Energy (1994).

40 CFR Part 192, "Health and Environmental Protection Standards for Uranium and Thorium Mill Tailings," U.S. Environmental Protection Agency (1994).

40 CFR Part 1500, "Regulations for Implementing the Procedural Provision of the National Environmental Policy Act," Council on Environmental Quality (1994). 


\section{FEDERAL CODE}

60 FR 2854, "Groundwater Standards for Remedial Actions at Inactive Uranium Processing Sites," Final Rule, January 11, 1995.

52 FR 36000, "Standards for Remedial Actions at Inactive Uranium Processing Sites, Proposed Rule," September 24, 1987.

\section{UNITED STATES CODE}

42 USC $\$ 7923$ et seq., Comprehensive National Energy Policy Act, October 24, 1992.

42 USC $\$ 7901$ et seq., Uranium Mill Tailings Radiation Control Act, November 8, 1978.

42 USC $\$ 4321$ et seq., National Environmental Policy Act, January 1, 1970. 